\title{
Articles
}

\section{Immigration Law After a Century of Plenary \\ Power: Phantom Constitutional Norms and \\ Statutory Interpretation}

\author{
Hiroshi Motomura $\uparrow$
}

CONTENTS

INTRODUCTION

I. Plenary Power as Constitutional Law 550

A. Classical Immigration Law $\quad 550$

B. Plenary Power in the Early Modern Era 554

II. PHANTOM NORMS, STATUTORY INTERPRETATION, AND CONSTITUTIONAL CHANGE $\quad 560$

A. Constitutional Norms and Statutory Interpretation 560

B. The Emergence of Phantom Norm Decisionmaking in
Immigration Law

C. Constitutional Change: From Phantom Norms to Real Norms 575

$\dagger$ Associate Professor of Law, University of Colorado School of Law. I would like to thank Alex Aleinikoff, Richard Collins, Richard Delgado, Philip Frickey, Glenn George, Stephen Legomsky, Mark Loewenstein, David Martin, James Nafziger, Robert Nagel, Gene Nichol, Peter Schuck, Steven Smith, Arthur Travers, and Charles Wilkinson for making many helpful comments and suggestions on ideas and earlier drafts. Elizabeth Griffin and Katherine Rice Mackey provided not only excellent research assistance, but also countless ideas and insights that contributed greatly to this Article's organization and substance. 
III. CONTEMporary Plenary POWER: Constitutional v. STATUTORY LAW

A. Phantom Norm Review of Executive Action 580

B. Jean v. Nelson and Other Phantom Norm Decisions 583

1. Race and National Origin Discrimination: Haitians and Others

2. Indefinite Detention of Mariel Cubans 593

3. Asylum Procedures for Excludable First-Time Entrants 595

4. First Amendment Challenges to Exclusion Grounds 597

IV. IN SEARCH OF CONSTITUTIONAL IMMIGRATION LAW 600

A. The Problem of Awkward or Unpredictable

Subconstitutional Solutions

600

B. The Problem of Misdirected Judicial Review 604

C. The Problem of Dialogue and the Future of Plenary Power 607

$[W] \mathrm{e}$ are in the never-never land of the Immigration and Nationality Act, where plain words do not always mean what they say. ${ }^{1}$

\section{INTRODUCTION}

The 1980 's witnessed a resurgence of interest in immigration law, especially in the role played by constitutional principles. Much of this interest is attributable to events that tested the limits of immigration law in unprecedented ways. The influx of Cubans in the Mariel boatlift and the large number of Haitians fleeing the Duvalier regime were the most prominent, but civil strife and economic conditions throughout the world further swelled the numbers of would-be immigrants. The result was an increased and often chaotic demand for a commodity in very short supply-lawful admission to the United States. And when the federal government tried to enforce the immigration laws in this setting, long and complicated litigation was the predictable result. These events forced courts to search for new answers to the fundamental questions that immigration law poses-who are "we" as a community, and what do we demand of those who want to join?

The most prominent case arising out of these developments is Jean $v$. Nelson, ${ }^{2}$ a 1985 decision of the United States Supreme Court that captures much of what is significant about the immigration law cases of the past decade. Jean involved the influx of Haitians into south Florida during the early 1980's, most of whom sought political asylum. The United States government adopted

1. Yuen Sang Low v. Attorney Gen., 479 F.2d 820, 821 (9th Cir. 1973).

2. 472 U.S. 846 (1985). 
a general practice of detaining these Haitians pending a decision on their asylum claims, and did not grant their requests to be released temporarily on "parole."3 The plaintiffs in Jean alleged that this detention policy denied equal protection because it discriminated on the basis of national origin and race against these Haitians, almost all of whom were Black. The case eventually reached the Supreme Court.

As I use the term, "immigration law" refers to the body of law governing the admission and expulsion of aliens. ${ }^{4}$ It should be distinguished from the more general law of aliens' rights and obligations, which includes, for example, their tax status, military obligations, and eligibility for government benefits and certain types of employment. ${ }^{5}$ Jean could have been the occasion for the Court to confront squarely the "plenary power doctrine." This doctrine has dominated immigration law since the Court adopted it almost one hundred years ago in rejecting constitutional objections to Congress' first immigration statutes. The plenary power doctrine's contours have changed over the years, but in general the doctrine declares that Congress and the executive branch have broad and often exclusive authority over immigration decisions. Accordingly, courts should only rarely, if ever, and in limited fashion, entertain constitutional challenges to decisions about which aliens should be admitted or expelled.

By the time Jean reached the Supreme Court, the doctrine had long been under heavy fire from many quarters. Critics expressed deep concern over the continuing isolation of an entire body of law from the mainstream of American public law-isolation not only from the process of constitutional judicial review, but also from the constitutional norms and principles developed through that process over the years. ${ }^{6}$ Even though the Court had endorsed some version of the plenary power doctrine in cases decided in the 1970's, a number of observers had predicted the gradual demise of the doctrine and a corresponding reintegration of our usual expectations regarding judicial review into immigration law. 8

The Jean decision, however, was anticlimactic because the majority did not reach the constitutional issue. Instead, it found that any discrimination against the Haitians based on race or national origin would be unlawful as contrary to the statute and the government's regulations. Many knowledgeable observers

3. See Immigration and Nationality Act of $1990, \S 212$ (d)(5), 8 U.S.C. $\$ 1182$ (d)(5) (1988) [hereinafter INA]; 47 Fed. Reg. 30,044 (1982) (as amended at 47 Fed. Reg. 46,493 (1982)) (amending 8 C.F.R. $\S \S 212.5,235.3)$.

4. The term "alien" is standard usage, but I use it advisedly because of the word's distancing effect and somewhat pejorative connotation. I also admit to some hypersensitivity on this point as a former "alien" myself.

5. This definition of "immigration law" is common to the literature. See, e.g., Legomsky, Immigration Law and the Principle of Plenary Congressional Power, 1984 SUP. CT. REv. 255, 256.

6. Schuck, The Transformation of Immigration Law, 84 COLUM. L. REV. 1 (1984) (immigration law isolated from other legal areas).

7. See Fiallo v. Bell, 430 U.S. 787 (1977); Kleindienst v. Mandel, 408 U.S. 753 (1972).

8. See, e.g., Legomsky, supra note 5; Schuck, supra note 6. 
saw Jean as a potential landmark decision that never was. Understandably, those observers had focused on the plenary power doctrine's substance-its denial to aliens of an opportunity to vindicate constitutional claims in immigration cases. I believe, however, that this focus on the most obvious consequence of plenary power has obscured its subtle, more fundamental effects on the process of growth and change in this field of law.

The broader subject suggested by Jean - but one never before explored in any depth-is the relationship between constitutional and subconstitutional immigration law. As I use the term here, "constitutional immigration law" means the application of constitutional norms and principles to test the validity of immigration rules in subconstitutional form, including statutes, regulations, and administrative guidelines. In contrast, "subconstitutional immigration law" means the interpretation and application of those statutes, regulations, administrative guidelines, and the like. Several commentators have noted that aliens tend to receive more favorable treatment when judges render subconstitutional decisions than when they render constitutional ones, but these observations have been made almost in passing, with little explanation or detail..$^{9}$ This Article will attempt to provide the missing analysis.

$I$ begin with a point that was central to Justice Marshall's dissent in Jean: nothing in the parole statute or regulations expressly prohibited the government from considering race or national origin in its parole decisions. ${ }^{10} \mathrm{He}$ is correct about the language of the statute and regulations. ${ }^{11}$ Also correct is his more general point that parole is one of many immigration matters committed by statute to the broad discretion of the Attorney General. ${ }^{12}$ What, then, prohibits the government from considering race or national origin when regulating the conduct of aliens? If this prohibition has a constitutional source, then was Jean a constitutional decision even though the Court purported to rule exclusively on statutory grounds? And if Jean was really a constitutional decision that implicitly upheld an equal protection claim, to what extent did this decision limit plenary power?

My ultimate purpose is to examine immigration law for what it tells us about a general problem of legal process-the relationship, usually symbiotic, between statutory interpretation and constitutional law. The usual pattern in our law, most observers would agree, is that constitutional norms manifest themselves in two principal ways. First, they govern expressly constitutional deci-

9. See S. LEGOMSKY, IMMIGRATION AND THE JUDICIARY: LAW AND POLITICS IN BRTTAIN AND AMERICA 233-35, 239-41, 252-53, 259, 300 (1987); D. MARTIN, MAJOR ISSUES IN IMMIGRATION LAW 19, 25-27 (1987); Anker, Jean v. Nelson: Neutra! Principles in the Supreme Court Without the Constitution, 8 IMMIGR. J. 9 (1985). I am indebted to these commentators, whose observations on the relationship between constitutional and subconstitutional immigration cases first raised in my mind the questions that this Article tries to answer.

10. Jean v. Nelson, 472 U.S. 846, $858-68$ (1985) (Marshall, J., dissenting).

11. The governing regulation at that time was 8 C.F.R. $\S 212.5$ (1982).

12. See 472 U.S. at 862-64. 
sions; this is the intuitive definition of "constitutional." Second, in a less intuitive but equally correct use of the term, "constitutional" norms provide the background context that informs our interpretation of statutes and other subconstitutional texts. This second use of constitutional norms explains and reflects the time-honored canon that courts ought to interpret statutes so as to avoid constitutional doubts.

Immigration law, as it has developed over the past one hundred years under the domination of the plenary power doctrine, represents an aberrational form of the typical relationship between statutory interpretation and constitutional law. The aberrant quality is attributable to the prolonged nature of the contradiction between these two sets of "constitutional" norms in immigration law. The constitutional norms that courts use when they directly decide constitutional issues in immigration cases are not the same constitutional norms that inform interpretation of immigration statutes. To serve the latter function, many courts have relied on what I call "phantom constitutional norms," 13 which are not indigenous to immigration law but come from mainstream public law instead. The result has been to undermine the plenary power doctrine through statutory interpretation.

In my view, any fair assessment of phantom norm decisionmaking should reflect deep ambivalence. On the one hand, it has been an understandable and perhaps even noble response to the shortcomings of the plenary power doctrine, and for that reason I do not intend the term "phantom" pejoratively. More generally, the use of phantom norms during a transitional phase may be a healthy form of constitutional change. On the other hand, statutory interpretation confuses and contorts the law when the interpreting court relies for an extended period on constitutional norms that are doctrinally "improper" in the sense that they do not control in cases which explicitly involve interpreting the Constitution. I suggest that the only way out of the dilemma posed by the prolonged reign of phantom norm decisionmaking in immigration law is to bring the transitional phase to an end-in short, to undertake a direct and candid reassessment of plenary power as constitutional doctrine.

In addition to the light that $I$ hope to shed on the relationship between statutory interpretation and constitutional law generally, I also will try to answer a more specific operational question, probably the most important one in immigration law today-what is left of the plenary power doctrine? A widely accepted view, with which I generally agree, is that the doctrine is in some state of decline. Yet the apparent conflicts and contradictions among the cases, and sometimes their open ambivalence, have frustrated the efforts of courts and commentators to be more precise about the doctrine's current vitality. I will suggest that the gradual demise of the plenary power doctrine is best understood as a function of the tension in immigration cases between constitutional doctrine

13. I am grateful to Alex Aleinikoff for suggesting the term "phantom norm." 
and statutory interpretation. The fact that the subconstitutional cases play such a central role in understanding plenary power means, in turn, that the doctrine's current vitality is the most important question not only in constitutional immigration law, but in immigration law as a whole. In short, this Article endeavors to provide a coherent theoretical and practical framework for all of immigration law, both constitutional and subconstitutional.

The discussion proceeds in four stages. Part I explains the advent and persistence of the plenary power doctrine as the dominant principle of constitutional and subconstitutional immigration law. Part II discusses the emergence of phantom norm decisions in the 1950's and 1960's. Part III analyzes more recent phantom norm decisions-most prominently Jean $v$. Nelson, but also similar cases in the lower courts. Part IV examines more closely the problems that arise when courts choose phantom constitutional norms to guide their interpretation of statutes.

\section{Plenary Power as Constitutional LaW}

\section{A. Classical Immigration Law}

The story of the plenary power doctrine's role in constitutional immigration law begins with the Supreme Court's 1889 decision in the Chinese Exclusion Case. ${ }^{14}$ Chae Chan Ping, a Chinese laborer, came to the United States in 1875, in a period when the Burlingame Treaty of 1868 seemed to guarantee unrestricted immigration from China. The United States had negotiated the treaty when it was interested in obtaining cheap Chinese labor and improving trade with China. ${ }^{15}$ But soon afterwards, racist and nativist anti-Chinese sentiment became widespread in California, and gradually gained influence on the national political scene.

In 1880, the two countries negotiated a supplemental treaty that allowed the United States to "regulate, limit or suspend" immigration of Chinese laborers. ${ }^{16}$ Those already here in November 1880 could continue "to go and come of their own free will and accord."17 In 1882, Congress suspended immigration of Chinese laborers for ten years. Those here who wished to leave and return could obtain certificates to show that they had come before November 1880 ,

14. Chae Chan Ping v. United States, 130 U.S. 581 (1889).

15. Justice Field's opinion gives a contemporary account of Chinese immigration to the United States. Id. at 590-98; see also Fong Yue Ting v. United States, 149 U.S. 698, 715-19 (1893). For more historical background, see T. ALEINIKOFF \& D. MARTIN, IMMIGRATION: PROCESS AND POLICY 1-5 (1985); R. TAKAKI, STRANGERS FROM A DIFFERENT SHORE 79-131 (1989).

16. The treaty authorized the United States to "regulate, limit or suspend" immigration of Chinese laborers whenever their entry or residence in the United States "affects or threatens to affect the interests of that country, or to endanger the good order of [the United States] or of any locality within the territory thereof." 130 U.S. at 596 (citing treaty). The United States could not "absolutely prohibit" immigration, and its power to suspend was limited to Chinese laborers. Id.

17. Id. 
and in 1884 these certificates became necessary for reentry. ${ }^{18}$ Chae Chan Ping obtained a certificate in 1887 and returned to his native China. The next year, while he was overseas, Congress barred the return of Chinese laborers, even those with certificates. Held on a ship in San Francisco Bay, Chae Chan Ping asserted two challenges to the 1888 statute in a petition for habeas corpus. His first argument was that the statute violated the 1880 treaty provision that Chinese laborers already here could leave and return. Justice Field acknowledged that the statute and treaty conflicted, but found that they were on an equal footing, and thus that the statute, being later in time, prevailed.

The second issue in the Chinese Exclusion Case was whether, as a constitutional matter, the 1888 statute was "beyond the competency of Congress to pass it." 19 Here the Court had its first chance to consider directly the federal government's power to exclude aliens, ${ }^{20}$ which the Constitution does not address explicitly. ${ }^{21}$ In setting out what was to become the conceptual framework for classical immigration law, the Court's concern was the federal government's power under the Constitution; ${ }^{22}$ it did not consider whether the rights of an individual alien might somehow limit Congress' immigration power. We must bear in mind that this was an earlier era of constitutional law, when equal protection was well on its way to "separate but equal," and judicial recognition of the substantive and procedural rights of individuals was still far beyond the constitutional horizon.

Justice Field's opinion established that the federal government has the power to regulate immigration, and it further suggested that the political branches could exercise this power without being subject to judicial review. ${ }^{23}$ He wrote that Congress' power to regulate immigration was based on national

\section{Id. at 598-99.}

19. Id. at 603.

20. Cf. Head Money Cases, 112 U.S. 580 (1884) (upholding federal tax on vessel owners of $50 \&$ for each alien brought into United States); The Passenger Cases, 48 U.S. (7 How.) 283 (1849) (invalidating state taxes on immigrants).

21. Cf. U.S. CONST. art. I, § 8, cl. 4 (power to "establish an uniform Rule of Naturalization").

22. Chae Chan Ping, 130 U.S. at 504 ("While under our Constitution and form of government the great mass of local matters is controlled by local authorities, the United States, in their relation to foreign countries and their subjects or citizens are one nation, invested with powers which belong to independent nations, the exercise of which can be invoked for the maintenance of its absolute independence and security throughout its entire territory.").

23. Some of the most often quoted language from the many cases that express this view is from Oceanic Steam Navigation Co. v. Stranahan, 214 U.S. 320 (1909), which held constitutional a levy on carriers who had brought inadmissible aliens to the United States: "[O]ver no conceivable subject is the legislative power of Congress more complete than it is over [the admission of aliens]." Id. at 339, quoted with approval, Fiallo v. Bell, 430 U.S. 787, 792 (1977); Kleindienst v. Mandel, 408 U.S. 753, 766 (1972); see also Lloyd Sabaudo Societa v. Elting, 287 U.S. 329, 334-35 (1932); Mahler v. Eby, 264 U.S. 32, 40 (1924); Lapina v. Williams, 232 U.S. 78, 88 (1914); Bugajewitz v. Adams, 228 U.S. 585, 591 (1913); Keller v. United States, 213 U.S. 138, $143-44$ (1909); United States ex rel. Turner v. Williams, 194 U.S. 279, 28992 (1904); Fok Yung Yo v. United States, 185 U.S. 296, 302 (1902); Li Sing v. United States, 180 U.S. 486, 495 (1901); United States v. Wong Kim Ark, 169 U.S. 649, $699-701$ (1898); cf. United States v. Ju Toy, 198 U.S. 253, 263 (1905) (applicant for admission has no right to de novo judicial review of his claim of citizenship); Lee Lung v. Patterson, 186 U.S. 168, 175-77 (1902) (upholding refusal to admit wife and daughter of returning resident of Chinese descent). 
security, sovereignty over its own territory, and self-preservation. ${ }^{24}$ "[If Congress] considers the presence of foreigners of a different race in this country, who will not assimilate with us, to be dangerous to its peace and security ... its determination is conclusive upon the judiciary."25 Justice Field also characterized the Chinese laborers' right to return as a license, revocable by the United States government. ${ }^{26}$ Suggesting that immigration cases might be nonjusticiable as political questions, Field wrote that any remedy for the aggrieved alien must be sought on the alien's behalf by the Chinese government from the political branches of the United States government. ${ }^{27}$

Two years later, in Nishimura Ekiu v. United States, ${ }^{28}$ the Court expanded the notion of plenary power in two significant ways. First, it rejected a challenge based on a claim of individual constitutional right. An administrative officer had found that a Japanese immigrant was likely to become a public charge, which in turn made her excludable under the statute. She argued that due process required a judicial proceeding. As in the Chinese Exclusion Case, the Court relied on maxims of international law and sovereignty ${ }^{29}$ to conclude that the immigration power belonged to the federal government and to the political branches, and thus was exempt from judicial review. ${ }^{30}$ Nishimura also broadened plenary power in a second way. While the Chinese Exclusion Case had upheld Congress' substantive admission and exclusion rules, Nishimura applied plenary power to Congress' procedures for enforcing immigration laws, including procedures that entrusted final decisionmaking power to agency officials. $^{31}$

24. 130 U.S. at 604 ("“Any restriction upon [the power to exclude aliens], deriving validity from an external source, would imply a diminution of its sovereignty to the extent of the restriction, and an investment of that sovereignty to the same extent in that power which could impose such restriction."” (quoting The Schooner Exchange v. M'Fadden, 11 U.S. (7 Cranch) 116, 136 (1812))); see also id. at 608 ("The power [to exclude paupers, criminals and persons afflicted with incurable diseases] is constantly exercised; its existence is involved in the right of self-preservation.").

25. 130 U.S. at 606.

26. Id. at 609 .

27. Id. at 606 ("If the government of the country of which the foreigners excluded are subjects is dissatisfied with this action it can make complaint to the executive head of our government, or resort to any other measure which, in its judgment, its interests or dignity may demand; and there lies its only remedy."); see also id. at 609 ("If there be any just ground of complaint on the part of China, it must be made to the political department of our government, which is alone competent to act upon the subject.").

28. 142 U.S. 651 (1892).

29. Id. at 659 ("It is an accepted maxim of international law, that every sovereign nation has the power, as inherent in sovereignty, and essential to self-preservation, to forbid the entrance of foreigners within its dominions, or to admit them only in such cases and upon such conditions as it may see fit to prescribe.").

30. Id. (Power over admission and exclusion "belongs to the political department.").

31. Id. at 660 ("[T]he final determination of those facts [establishing an alien's right to land] may be entrusted by Congress to executive officers; and in such a case, as in all others, in which a statute gives a discretionary power to an officer, to be exercised by him upon his own opinion of certain facts, he is made the sole and exclusive judge of the existence of those facts, and no other tribunal, unless expressly authorized by law to do so, is at liberty to reexamine or controvert the sufficiency of the evidence on which he acted"); see also Lem Moon Sing v. United States, 158 U.S. 538, 541-47 (1895) (following Nishimura Ekiu). 
In Fong Yue Ting v. United States, ${ }^{32}$ decided in 1893, the Court further extended plenary power to the deportation of resident aliens already in the United States. An 1892 statute had extended the ban on Chinese immigration for ten years. Those already resident when the ban took effect were allowed to stay, but only if they could prove pre-1892 residency through a white witness. ${ }^{33}$ Fong and two other Chinese laborers claimed pre-1892 residency, but could not produce white witnesses. Justice Gray's majority opinion rejected Fong's constitutional challenge, based on procedural due process, to the white witness rule. Gray declined to distinguish between the power to deport and the power to exclude, ${ }^{34}$ dismissing the idea that deportation should trigger the more substantial constitutional safeguards associated with "punishment."35 Relying on the Chinese Exclusion Case and Nishimura Ekiu, he concluded that the political branches could regulate immigration, immune from judicial review unless provided for by Congress. ${ }^{36}$

The three dissenters in Fong advanced arguments that would prove influential in later attempts to limit the plenary power doctrine. Justice Brewer argued that deportation should prompt greater concern than exclusion because constitutional protections apply within United States territory even if they do not apply outside it. ${ }^{37}$ All three dissenters suggested that resident aliens have ties to the United States that justify greater legal protection, ${ }^{38}$ and that Fong's constitutional challenge merited judicial attention because the "credible white witness" rule violated procedural due process. ${ }^{39}$ Justices Brewer and Fuller took the position that deportation was "punishment" to which constitutional safeguards

32. 149 U.S. 698 (1893).

33. Under the statute, residency was to be proved by a certificate, which under the regulations required the "affidavit of at least one credible witness." See id. at $701 \mathrm{n} .1$ (citing statute and regulations). The statute allowed for deportation of those without certificates unless they showed good cause for not obtaining one and proved pre-1892 residency through a "white" witness. Id. at 700 n.1.

34. Id. at 713 ("The power to exclude aliens and the power to expel them rest upon one foundation, are derived from one source, are supported by the same reasons, and are in truth but parts of one and the same power.").

35. Id. at 730 ("The order of deportation is not a punishment for crime. It is not a banishment, in the sense in which that word is often applied to the expulsion of a citizen from his country by way of punishment. It is but a method of enforcing the return to his own country of an alien who has not complied with the conditions upon the performance of which the government of the nation, acting within its constitutional authority and through the proper departments, has determined that his continuing to reside here shall depend.") (distinguishing Yick Wo v. Hopkins, 118 U.S. 356 (1886), as concerning "the power of a State over aliens continuing to reside within its jurisdiction, not of the power of the United States to put an end to their residence in the country").

36. 149 at 715. See also id. at 706 ("conclusive upon the [J]udiciary"); id. at 711 ("The United States are a sovereign and independent nation, and are vested by the Constitution with the entire control of international relations, and with all the powers of government necessary to maintain that control and to make it effective.").

37. Id. at 738 (Brewer, J., dissenting).

38. Id. at 734-37 (Brewer, J., dissenting); id. at 746 (Field, J., dissenting); id. at 762 (Fuller, J., dissenting).

39. Id. at 741-42 (Brewer, J., dissenting); id. at 754 (Field, J., dissenting); id. at 762-63 (Fuller, J., dissenting). Justice Gray's majority opinion characterized the "credible white witness" rule as a mere rule of evidence. Id. at 729-30. 
should apply. ${ }^{40}$ Interestingly, Fong and the dissenters all seemed to assume that Congress' decision to single out Chinese aliens was not open to challenge. ${ }^{41}$

The first sign that the Fong dissents would be influential came in a 1903 decision, Yamataya v. Fisher, ${ }^{42}$ also known as the Japanese Immigrant Case. The government arrested and tried to deport Yamataya four days after she had landed in the United States. Although the Court did not question the validity of the plenary power doctrine in general, ${ }^{43}$ in refusing to allow deportation it relied on two of the grounds suggested by the Fong dissenters. According to the Court, aliens inside the United States can invoke more constitutional safeguards than aliens seeking admission, and courts reviewing deportation orders should examine procedural due process questions more closely than they should examine substantive immigration rules. ${ }^{44}$

These four cases established a classical immigration law ${ }^{45}$ with two significant dimensions-the alien's location and the nature of the constitutional challenge to an adverse immigration decision. The Chinese Exclusion Case and Nishimura Ekiu suggested that no constitutional objection by an alien outside the United States would be successful. All of the Fong Yue Ting opinions assumed that an alien in the United States who challenged substantive deportation rules would likewise be unsuccessful. Finally, Yamataya suggested that an alien in the United States who objected to deportation procedures might have some success.

\section{B. Plenary Power in the Early Modern Era}

As Peter Schuck has pointed out, the plenary power cases of classical immigration law reflect an emphasis on territoriality that was consistent with the sovereignty and consent-based legal culture of the nineteenth century. ${ }^{46}$ It is noteworthy, if not striking, that the doctrine, a product of the same era as

40. Id. at 740 (Brewer, J., dissenting); id. at 763 (Fuller, J., dissenting). See generally Schuck, supra note 6 , at $66-68$.

41. The Court upheld the constitutionality of substantive discrimination against specified classes of aliens in Lees v. United States, 150 U.S. 476, 480 (1893). See also United States ex rel. Turner v. Williams, 194 U.S. 279, 294 (1904) (deportation of anarchist withstands First Amendment challenge).

42. 189 U.S. 86 (1903).

43. Id. at $97-98$.

44. Id. at 101 (" $[\Pi] \mathrm{t}$ is not competent for . . . any executive officer . . . arbitrarily to cause an alien, who has entered the country, and has become subject in all respects to its jurisdiction, and a part of its population, although alleged to be illegally here, to be taken into custody and deported without giving him all opportunity to be heard upon the questions involving his right to be and remain in the United States.").

45. I borrow this term from Schuck, supra note 6.

46. See id. at 7-8. On the historical and theoretical bases of the plenary power doctrine, see S. LEGOMSKY, supra note 9, at 177-222; Legomsky, supra note 5, at 260-78; Note, Constitutional Limits on the Power to Exclude Aliens, 82 CoLum. L. REV. 957 (1982). Cf. Wani, Truth, Strangers, and Fiction: The Illegitimate Uses of Legal Fiction in Immigration Law, 11 CARDOZO L. REV. 51, 59-83 (1989) (criticizing "fiction of sovereignty"). 
Plessy v. Ferguson, ${ }^{47}$ has faded so little with the passage of time. A number of decisions in the first half of this century might be read as ameliorating the doctrine's harshest aspects, especially by building on Yamataya's apparent requirement of some procedural due process in deportation. ${ }^{48}$ Yet the Supreme Court reinvigorated the doctrine in a series of cases decided in the McCarthy Era, three of which are particularly important.

The first, United States ex rel. Knauff $v$. Shaughnessy, ${ }^{49}$ involved Ellen Knauff, who fled her native Germany after the Nazi seizure of power and served in Great Britain's Royal Air Force during World War II. She worked with the Allied occupation forces in Germany after the war, and in 1948 she married a United States citizen. Later that year she sought to enter the United States to be naturalized. The government, without a hearing, ordered her permanently excluded on the ground that her admission would be prejudicial to the interests of the United States. Not knowing what had prompted this order, she challenged it by seeking a writ of habeas corpus; the lower courts rejected her petition. Over vigorous dissent, the Supreme Court affirmed the exclusion order in language reminiscent of the nineteenth-century cases. The Court held that the power to exclude aliens, even the wife of a citizen, is fundamental to sovereignty. Unless Congress provides otherwise, that power is beyond judicial review, especially during national emergency, and it includes procedure as well

47. 163 U.S. 537 (1896).

48. Deportation cases to this effect include United States ex rel. Vajtauer v. Commissioner of Immigration, 273 U.S. 103, 106 (1927) ("Deportation without a fair hearing or on charges unsupported by any evidence is a denial of due process."); United States ex rel. Tisi v. Tod, 264 U.S. 131, 133 (1924) (similar); Lewis v. Frick, 233 U.S. 291, 300 (1914) (similar); Zakonaite v. Wolf, 226 U.S. 272, 275 (1912) (deportation based on agency factfinding "after a fair though summary hearing, may constitutionally be made conclusive"); Low Wah Suey v. Backus, 225 U.S. 460, 468 (1912) (similar); $c f . ~ N g$ Fung Ho v. White, 259 U.S. 276, 281-85 (1922) (due process requires judicial proceeding before person claiming to be citizen, and presenting evidence to that effect, can be deported).

Similar exclusion cases all involved claims of United States citizenship. For example, Kwock Jan Fat v. White, 253 U.S. 454 (1920), held that an administrative decision to exclude a returning resident of Chinese descent, who claimed United States citizenship, was final and conclusive upon United States courts unless such a funding were

"manifestly unfair," were "such as to prevent a fair investigation," or show "manifest abuse" of the discretion committed to the executive officers by the statute, Low Wah Suey, [225 U.S. 460, 468 (1912)], or that "their authority was not fairly exercised, that is, consistently with the fundamental principles of justice embraced within the conception of due process of law." Tang Tun v. Edsell, [223 U.S. 673, 681-81 (1912)]. The decision must be after a hearing in good faith, however summary, Chin Yow v. United States, 208 U.S. 8, 12 (1908), and it must find adequate support in the evidence. Id. at 457-58; see also Tang Tun, 223 U.S. at 675-82 (constitutional to refuse admission after "careful and fair" administrative hearing to returning resident of Chinese descent who claimed United States citizenship); Chin Yow v. United States, 208 U.S. 8, 12 (1908) ("The decision of the Department is final, but that is on the presupposition that the decision was after a hearing in good faith, however summary in form."); $c f$. Lloyd Sabaudo Societa v. Elting, 287 U.S. 329, 335-36 (1932) (fine imposed on steamship company for transporting aliens found inadmissible is valid if procedure "satisfies elementary standards of fairness and reasonableness"). See generally Hart, The Power of Congress to Limit the Jurisdiction of the Federal Courts: An Exercise in Dialectic, 66 HARV. L. REV. 1362, 1390-91 (1953) (noting growth of a body of law qualifying the plenary power doctrine); Developments in the Law-Immigration and Nationality, 66 HARV. L. REV. 643, 674-76 (1953) (similar).

49. 338 U.S. 537 (1950). 
as substance..$^{50}$ The Court declared with a quiet, chilling brutality: "Whatever the procedure authorized by Congress is, it is due process as far as an alien denied entry is concerned." 51

The second case, Shaughnessy v. United States ex rel. Mezei, ${ }^{52}$ involved a permanent resident who had lived in the United States for twenty-five years. In 1948, leaving his wife at home, Mezei traveled to Eastern Europe, apparently to visit his dying mother. While there, Mezei had trouble obtaining the necessary exit papers to embark on his journey back home. When he finally arrived on this country's shores, in possession of an immigration visa issued by the American Consul in Budapest, the government excluded him without a hearing, on the "basis of information of a confidential nature, the disclosure of which would be prejudicial to the public interest." 53 No other country would take Mezei, so the government confined him indefinitely on Ellis Island. He remained in custody for twenty-one months before a district court first granted a writ of habeas corpus ordering his release.

One might have expected the law, in the form of either the immigration statute or constitutional immigration law, to treat a long-time permanent resident less harshly than it would treat a first-time entrant. But with respect to the statute, any such hopes were unfounded. The Immigration and Nationality Act (INA) and its predecessor statutes, like the constitutional immigration law of the classical period, have been structured to ask first if an alien is located inside or outside the country. The alien's location then determines which of two basic sets of rules apply - admission rules, which are tied to quotas and supplemented by exclusion rules, or deportation rules, which expel aliens who should not have been admitted or who have committed bad acts after admission. ${ }^{54}$

50. Id. at 542-43 ("Whatever the rule may be concerning deportation of persons who have gained entry into the United States, it is not within the province of any court, unless expressly authorized by law, to review the determination of the political branch of the Government to exclude a given alien.").

51. Id. at 544. Eventually, the government revealed the adverse information at a full hearing, and the immigration judge still found her excludable. The Board of Immigration Appeals (BIA) then reversed and admitted her. For more background, see E. KNAUFF, THE ELLEN KNAUFF STORY (1952).

52. 345 U.S. 206 (1953).

53. Id. at 208. The government relied on the Act of June 21,1941 , ch. $210, \S 1,55$ Stat. 252 (currently codifed as amended at 8 U.S.C. $\S 1225$ (c), INA $\S 235$ (c), and 8 C.F.R. $\S 175.57$ ).

54. Starting in 1875 , immigration statutes began to exclude some aliens on the basis of national origin. Other statutes applied to all countries but excluded certain types of undesirables. See Act of Feb. 20, 1907, ch. 1134, § 2, 34 Stat. 898, 898-99; Act of Mar. 3, 1903, ch. 1012, § 2, 32 Stat. 1213, 1214; Act of Mar. 3, 1891, ch. 551, § 1, 26 Stat. 1084, 1084; Act of Aug. 3, 1882, ch. 376, § 2, 22 Stat. 214, 214 (lunatics, idiots, convicts, and those liable to become a public charge); Act of Mar. 3, 1875, ch. 141, § 5, 18 Stat. 477,477 (excluding prostitutes and convicts). In 1917, Congress enacted legislation that codified the existing categories of excludable aliens, excluded illiterates for the first time, and banned almost all Asian immigration. Act of Feb. 5, 1917, ch. 29, \& 3, 39 Stat. 874, 875-78.

Alongside these exclusion statutes, Congress enacted the predecessors of today's deportation grounds. At first, these laws were limited to removing aliens who had entered in violation of the admission and exclusion statutes. Beginning in 1907, however, Congress provided for the deportation of aliens for acts committed after arrival. Act of Feb. 20, 1907, ch. 1134, § 3, 34 Stat. 898, 899-900. Cf. Act of June 25, 1798 , ch. 58, \& 1, 1 Stat. 570, 571 (President may order any alien whom he judged "dangerous to the peace and safety of the United States" to leave country without hearing); Act of July 6, 1798, ch. 66, § 1, 1 Stat. 577, 577 (President during war may apprehend, restrain, secure and remove all enemy aliens without 
The key statutory question has always been whether an alien has "entered" the United States, which can occur through the government's decision to admit her or through a surreptitious border crossing. 55 If an alien has not entered but seeks entry, the admission and exclusion rules apply; after entry, deportation rules apply. ${ }^{56}$ To be sure, "entry" could be defined to include only an alien's first entry, thus categorizing returning permanent residents as deportable rather than excludable. But the Court had unmistakably rejected this view long before Mezei by establishing the "reentry doctrine," which subjects returning permanent residents to exclusion grounds and procedures each time they return to this country from a trip, however brief. ${ }^{57}$ Congress largely incorporated the reentry

hearing). See generally Kleindienst v. Mandel, 408 U.S. 753, 761 (1972); Harisiades v. Shaughnessy, 342 U.S. 580, 588 n.15 (1952); T. ALEINIKOFF \& D. MARTIN, supra note 15, at 348-49.

Then, in 1924, the National Origins Act, our first comprehensive immigration statute, established a quota system that tied immigration from each foreign land to its share of the existing United States population. Act of May 26, 1924, ch. 190, $\S 11,43$ Stat. 153, 159-60. In addition, the National Origins Act limited European immigration to 150,000 annually. Id. \& 11 . Without expressly mentioning Japan, it also barred Japanese immigration altogether by prohibiting the admission of any alien "ineligible to citizenship." Id. \& 13(c), a phrase clearly intended to apply to Japanese. See generally R. TAKAKI, supra note 15, at 20810. In 1921, Congress had adopted the first quotas in a provisional measure that capped European immigration and limited the number of immigrants of each nationality to three percent of their foreign-born countrymen resident in the United States as of the 1910 census. Act of May 19, 1921, ch. 8, § 2, 42 Stat. 5, 5. The McCarren-Walter Act of 1952, Pub. L. No. 82-414, 66 Stat. 163, consolidated previous immigration laws, and per-country limits replaced the national origins quotas in 1965. Immigration and Nationality Act Amendments of 1965, Pub. L. No. 89-236, § 2, 79 Stat. 911, 911-12. Through all of these changes, the basic immigration statute has continued to rely on admission rules tied to quotas and supplemented by exclusion rules, and deportation rules for aliens who should not have been admitted or who have committed bad acts after admission.

55. "Admission" is a term of art and does not include the granting of permission to enter the country on parole. See Leng May Ma v. Barber, 357 U.S. 185, 188 (1958). This article will not discuss the close questions that can arise when a surreptitious border crossing is claimed to constitute an "entry." See generally T. ALEINIKOFF \& D. MARTIN, supra note 15, at 315-23; id. at 25-26 (Supp. 1987).

56. Generally, admission criteria are set forth in INA $\S \S 201-203,8$ U.S.C. $\S \S 1151-1153$ (1988), exclusion grounds in INA $\S 212,8$ U.S.C. $\$ 1182$ (1988), and deportation grounds in INA $\S 241$, 8 U.S.C. $\S 1251$ (1988).

57. The most prominent of these cases is United States ex rel. Volpe v. Smith, 289 U.S. 422 (1933). Volpe entered the United States from Italy in 1906, when he was 16 years old. In 1925, he pleaded guilty to counterfeiting and was sentenced to prison. In 1928, he visited Cuba briefly, and two years later the government sought to deport him for having committed a crime of "moral turpitude" before entry. The deportation statute applied to "any alien who was convicted, or who admits the commission, prior to entry, of a felony or other crime or misdemeanor involving moral turpitude." Act of Feb. 5, 1917, ch. 29, § 19, 39 Stat. 874, 889. Volpe was deportable only if his return from Cuba in 1928 had been an "entry," as the government urged. Otherwise, if he had last entered in 1906, the statute would not apply because the crime was not before entry. Another deportation ground, for a single crime within five years after entry, also would not apply because 19 years had passed. 289 U.S. at 426 . A unanimous Court agreed with the government's reading of "entry" and upheld the deportation order. Id. at 425 . See also United States ex rel. Stapf v. Corsi, 287 U.S. 129, 132 (1932); United States ex rel. Claussen v. Day, 279 U.S. 398, 401 (1929); Lewis v. Frick, 233 U.S. 291, 297 (1914); Lapina v. Williams, 232 U.S. 78, 91 (1914); cf. Wani, supra note 46, at 89-96 ("entry" fiction is primary determinant of procedural due process despite its "acknowledged falsity and outrageousness"). See also Maslow, Recasting Our Deportation Law: Proposals for Reform, 56 Colum. L. REV. 309, 327-29 (1956) (criticizing reentry doctrine for its "harsh consequences").

On the facts of Volpe, this decision did not directly distinguish between exclusion and deportation; Volpe had entered the United States in 1928, making it too late to exclude him, so the government had to deport him if it was to act against him. The underlying logic of the decision, however, was that Volpe's 22 years in the United States made no difference. If, for example, the government had stopped Volpe at the border upon his return from Cuba in 1928, he would have been "entering" at that time and thus subject 
doctrine into the 1952 Immigration Act, when it defined "entry" to mean "any coming of an alien into the United States."

Because the reentry doctrine dashed Mezei's hopes for success on statutory grounds, the Court had to decide if the statute could constitutionally apply to a returning permanent resident the same exclusion rules that the statute would apply to a first-time entrant, including denial of a hearing. Relying on the plenary power doctrine and national security considerations, but once again over vigorous dissent, the Court said that the statute could deny Mezei both substantive rights and procedural safeguards available to deportable aliens. ${ }^{59}$ The Court characterized Mezei's constitutional position, like his position under the statute, as that of "an alien on the threshold of initial entry." sought to distinguish his case from Knauff by arguing that he, unlike Knauff, sought not just admission, but also release from indefinite detention. The Court rejected this argument as well, characterizing his incarceration as "temporary harborage, an act of legislative grace." Eventually, Mezei was paroled into the United States under a special clemency measure, but only after spending four years in detention. ${ }^{62}$

The third case, the 1952 decision in Harisiades v. Shaughnessy, ${ }^{63}$ involved substantive immigration categories, in contrast to the procedural claims in Knauff and Mezei. The Court upheld the deportations of Harisiades and two other resident aliens for having once belonged to the United States Communist Party, even though they were no longer members when that ground for deportation became law. ${ }^{64}$ While Knauff and Mezei had shown that an alien's location outside the United States would place him in a very precarious constitutional position, and Yamataya had established that location inside the United States

to exclusion rather than deportation grounds and procedures.

58. Pub. L. No. 82-414, Act of June 27, 1952, ch. 477, $\S 101,66$ Stat. 163, 167 (emphasis added). The 1952 legislation put an end to arguments, see, e.g., T. ALEINIKOFF \& D. MARTIN, supra note 15, at $326-27$, that in reading "entry" to include a permanent resident's return, Volpe conflicted with the overall structure of the statutory exclusion and deportation grounds. The present definition of "entry" is set forth in INA \& 101(a)(13), 8 U.S.C. $\$ 1101$ (a)(13) (1988).

59. Mezei, 345 U.S. at 210 ("Courts have long recognized the power to expel or exclude aliens as a fundamental sovereign attribute exercised by the Government's political departments largely immune from judicial control.").

60. Id. at 212 (distinguishing Yamataya v. Fisher, 189 U.S. 86 (1903), discussed in Part I.A). See also id. at 213 ("For purposes of the immigration laws, moreover, the legal incidents of an alien's entry remain unaltered whether he has been here once before or not. He is an entering alien just the same, and may be excluded if unqualified for admission under existing immigration laws.").

61. Id. at 215 .

62. See Trop v. Dulles, 356 U.S. 86,102 n.36 (1957).

63. 342 U.S. 580 (1952).

64. For years, Congress tried to deport aliens who were Communists or otherwise regarded as subversives. In 1939, the Supreme Court construed the deportation statute then in effect to allow the deportation of aliens who were members of organizations that advocated the overthrow of the government by force and violence, but not to allow deportation once membership had ceased. Kessler v. Strecker, 307 U.S. 22 (1939). In response, the Communist Party struck aliens from its membership rolls to spare them the risk of deportation. Congress in turn enacted a new statute that made aliens deportable if they had been members of the proscribed organizations at any time. See Alien Registration Act of 1940, Pub. L. No. 670, ch. 439, $\S 23,54$ Stat. 670, 673 (1940). The deportations in Harisiades were based on this second statute. 
would enhance his ability to raise procedural constitutional challenges, Harisiades demonstrated that location inside the country would not necessarily facilitate substantive claims. The Court rejected arguments rooted in the Fifth Amendment due process clause that aliens, once admitted to permanent residence, have a "vested right" to remain, or, alternatively, that any deportation grounds for permanent residents must be "reasonable." 65 The Court's language suggested little if any judicial role: "[A]ny policy toward aliens is vitally and intricately interwoven with contemporaneous policies in regard to the conduct of foreign relations, the war power, and the maintenance of a republican form of government." 66 According to the Court, "[s]uch matters are so exclusively entrusted to the political branches of government as to be largely immune from judicial inquiry or interference." 67 The Court also rejected the argument that the First Amendment barred deportation, in reasoning that seemed to assume that the First Amendment did not protect the Communist Party membership of anyone, citizen or alien. ${ }^{68}$ Finally, the Court rejected the claim that Harisiades' deportation rested on an unconstitutional ex post facto law, reasoning that statute was not retroactive, and that even if it were, the constitutional prohibition would not apply because deportation is a "civil" proceeding. ${ }^{69}$

65. Harisiades, 342 U.S. at 586-87 ("Under our law, the alien in several respects stands on an equal footing with citizens, but in others has never been conceded legal parity with the citizen. Most importantly, to protract this ambiguous status within the country is not his right but is a matter of permission and tolerance. The Government's power to terminate its hospitality has been asserted and sustained by this Court since the question first arose.").

66. $I d$. at 588-89.

67. Id. at 589 (footnote omitted). Two years later, in Galvan v. Press, 347 U.S. 522, 529-32 (1954), the Court relied on Harisiades to uphold the constitutionality of the Internal Security Act of 1950, Pub. L. No. 81-831, ch. 1024, tit. I, § 22, 64 Stat. 987, 1006 (1950) (substantially codified in INA § 241(a)(6)(C), 8 U.S.C. $\S 1251$ (a)(6)(C) (1988)), which dispensed with the need under the Alien Registration Act of 1940 to prove in each deportation that the Communist Party did "advocate the violent overthrow of the Government." Justice Frankfurter wrote "that the formulation of these [admission and expulsion] policies is entrusted exclusively to Congress has become about as firmly embedded in the legislative and judicial tissues of our body politic as any aspect of our government." 347 U.S. at 531. See also Jay v. Boyd, 351 U.S. 345, $357 \mathrm{n.21}$ (1956) (constitutionality of statute permitting Attorney General to deny suspension of deportation to former Communist Party member on basis of undisclosed confidential information "gives us no difficulty"); Carlson v. Landon, 342 U.S. 524, 534 (1952) ("So long . . . as aliens fail to obtain and maintain citizenship by naturalization, they remain subject to the plenary power of Congress to expel them under the sovereign right to determine what noncitizens shall be permitted to remain within our borders.") (footnote omitted).

68. 342 U.S. at 591-93. The Court's reliance on Dennis v. United States, 341 U.S. 494 (1951), suggests that it made this assumption. Because First Amendment law has changed significantly since Harisiades, later cases might pose the question whether an alien can be deported for activity that would be constitutionally protected for United States citizens. See generally T. ALEINIKOFF \& D. MARTIN, supra note 15, at 365 66. The court in American-Arab Anti-Discrimination Comm. v. Meese, 714 F. Supp. 1060, 1077-82 (C.D. Cal. 1989), reasoned that an alien's First Amendment challenge to a deportation ground must be analyzed just as if a citizen had raised it, and struck down certain ideological deportation grounds as unconstitutional. For a more detailed discussion of American-Arab Anti-Discrimination Committee see infra text accompanying notes 352-57.

69. 342 U.S. at 593-95 (citing Mahler v. Eby, 264 U.S. 32, 39 (1924), and Bugajewitz v. Adams, 228 U.S. 585, 591 (1913)). See also Flemming v. Nestor, 363 U.S. 603, 612-21 (1960); Lehmann v. United States ex rel. Carson, 353 U.S. 685, $689-90$ (1957); Marcello v. Bonds, 349 U.S. 302, 314 (1955); Galvan v. Press, 347 U.S. 522, 530-31 (1954). 
Taken together, Knauff, Mezei, and Harisiades confirmed the modern importance of the two basic lines of inquiry in the early plenary power decisions: the alien's location and the type of constitutional challenge. Specifically, aliens "outside" the United States would continue to find it very difficult to raise any constitutional challenge to immigration decisions. Those "inside" the United States could have some success with procedural claims but would be likely to have none with substantive claims. At the same time, spirited dissents in all three cases expressed serious concern that aliens would be denied access to judicial review in such harsh and unremitting terms. In Mezei, the dissenters were particularly troubled by the majority's upholding as constitutional the statute's treatment of a returning permanent resident, effectively limiting Mezei's substantive and procedural rights to those of exclusion rather than deportation. In both Knauff and Mezei, the apparent disregard for even the most rudimentary procedural due process troubled the dissenters, just as it had been a primary focus of the Fong Yue Ting dissents, and of the Court's opinion in Yamataya. ${ }^{70}$ And in Harisiades, Justice Douglas, relying heavily on Justice Brewer's dissent in Fong Yue Ting, ${ }^{71}$ argued that resident aliens cannot be deported unless they are afforded constitutional protections, especially due process and equal protection. ${ }^{72}$ Gradually, the concerns expressed in the dissents in Mezei, Knauff, and Harisiades found sympathetic ears. The result has been an expansion in the number and range of claims that courts, including the Supreme Court, would hear in immigration cases.

\section{Phantom NoRms, Statutory INTERPRETATION, AND CONSTTTUTIONAL CHANGE}

\section{A. Constitutional Norms and Statutory Interpretation}

The principal decisions that have contributed to this expansion of judicial review in immigration cases have not been decisions of constitutional immigration law. Instead, they reached results favorable to aliens by interpreting statutes, regulations, or other forms of subconstitutional immigration law. Of course, there is nothing remarkable about a court decision that relies on a subconstitutional rather than constitutional ground. A time-honored canon of

70. See Mezei, 345 U.S. at 224 (Jackson, J., dissenting) ("Procedural due process is more elemental and less flexible than substantive due process. It yields less to the times, varies less with conditions, and defers much less to legislative judgment."). See also Knauff, 338 U.S. at 552 (Jackson, J., dissenting) (objecting to "a finding of serious misconduct against the wife of an American citizen without notice of changes, evidence of guilt and a chance to meet it"). In contrast, Jackson had written for the Harisiades majority in rejecting a substantive constitutional challenge. Sharp criticism of Knauff and Mezei was also expressed in Hart, supra note 48, at 1391-96 (Knauff's statement of complete acquiescence in procedure prescribed by Congress is "a patently preposterous proposition").

71. For a discussion of Fong Yue Ting v. United States, 149 U.S. 698 (1893), see supra text accompanying notes $32-41$.

72. 342 U.S. at 598 (Douglas, J., dissenting). 
statutory interpretation, often invoked by citing Justice Brandeis' 1936 concurrence in Ashwander $v$. Tennessee Valley Authority, ${ }^{73}$ says that judges should interpret statutes to avoid constitutional doubt. ${ }^{74}$ While this canon is not uncontroversial, ${ }^{75}$ and its predictive value is open to question, ${ }^{76}$ reliance on the canon, whether stated or unstated, seems to be a fact of everyday judicial life.

The canon largely reflects the fact that constitutional norms usually manifest themselves in our law both directly and indirectly. First, constitutional norms may directly govern decisions that are expressly constitutional; this is the intuitive definition of "constitutional." In a less intuitive but equally correct use of the term "constitutional," these norms operate indirectly, by serving as the unstated background context that informs our interpretation of statutes and other subconstitutional texts. In other words, contemporary constitutional law is a significant element of the legal culture that judges inevitably, if often subconsciously, absorb and rely upon when acting in their judicial capacity, including those instances in which they engage in statutory interpretation. ${ }^{77}$

73. 297 U.S. 288, 347 (1936) (Brandeis, J., concurring).

74. See Jean v. Nelson, 472 U.S. 846, 854 (1985); see also Public Citizen v. United States Dep't of Justice, 109 S. Ct. 2558, 2572-73 (1989); Edward J. DeBartolo Corp. v. Florida Gulf Coast Bldg. \& Constr. Trades Council, 485 U.S. 568, 575-77 (1988); United States v. Clark, 445 U.S. 23, 27 (1980); NLRB v. Catholic Bishop, 440 U.S. 490, 499-501 (1979); International Ass'n of Machinists v. Street, 367 U.S. 740, 749 (1961). See generally W. ESKRIDGE \& P. FRICKEY, LEGISLATTON: STATUTES AND THE CREATION OF PUBLIC POLICY 676-89 (1988); Eskridge, Public Values in Statutory Interpretation, 137 U. PA. L. REV. 1007, 1020-22 (1989). A closely related canon is the "rule of lenity" in criminal cases. See United States v. Campos-Serrano, 404 U.S. 293, 298-99 (1971); Eskridge, supra, at 1029-30.

75. Judge Posner, for example, objects that this practice allows courts to bend the meaning of statutes, thereby creating an inappropriate judge-made "penumbra" around the Constitution. See R. POSNER, THE FEDERAL COURTS 285 (1985). See also United States v. Monsanto, 109 S. Ct. 2657, 2664 (1989) ("such "interpretive canon[s are] not a license for the judiciary to rewrite language enacted by the legislature" ") (quoting United States v. Albertini, 472 U.S. 675, 680 (1985)); Public Citizen v. United States Dep't of Justice, 109 S. Ct. 2558, 2580 (1989) (Kennedy, J., concurring) ("The fact that a particular application of the clear terms of a statute might be unconstitutional does not provide us with a justification for ignoring the plain meaning of the statute."); NLRB v. Catholic Bishop, 440 U.S. 490, $510-11$ (1979) (Brennan, J., dissenting) (to confine judiciary to its proper role, canon for construing statutes wherein constitutional questions may lurk must be limited to constructions that are fairly possible); H. FREENDLY, BENCEMARKS 210-12 (1967); Posner, Statutory Interpretation-In the Classroom \& in the Courtroom, 50 U. CHI. L. REV. 800, 815-16 (1983).

76. See, e.g., Webster v. Reproductive Health Servs., 109 S. Ct. 3040, 3064-65 (1989) (Scalia, J., concurring) ("a sound general principle, but one often departed from when good reason exists. ... I have not identified with certainty the first instance of our deciding a case on broader constitutional grounds than absolutely necessary, but it is assuredly no later than Marbury v. Madison ... ."). See also Eskridge, supra note 74, at 1073 ('for every case like Catholic Bishop, which interprets statutes to avoid constitutional doubts, there are other cases where a statute is construed boldly, to face substantial constitutional troubles").

77. See, e.g., Eskridge \& Frickey, Statutory Interpretation as Practical Reasoning, 42 STAN. L. REV. $321,352(1990)$ ("Because we always approach texts from the perspective of our own historically situated horizon, we tend to project our 'preunderstandings' onto the text, viewed as a whole. That is essential to interpretation, because the preunderstandings are conditioned by tradition and, hence, help us link our horizon with that of the text."); Smith, Law Without Mind, 88 MICH. L. REV. 104, 106-07 (1989) ("The pragmatic judge would not necessarily spurn traditional legal authorities, like statutes or constitutional provisions, in part because such authorities may prove to be useful tools, and in part because they may in fact have given rise to practices and expectations which the pragmatic calculus must take into account."); Sunstein, Interpreting Statutes in the Regulatory State, 103 HARV. L. REv. 405, 411 (1989) (statutory interpretation relies on background principles drawn from context and, more generally, from legal culture); $i d$. at 459 ("Interpretive principles are often a product of constitutional norms."); id. at 468 ("the Constitution 
Bob Jones University v. United States ${ }^{78}$ illustrates how constitutional norms inform statutory interpretation. A nearly unanimous Court held that a nonprofit private school with racially discriminatory admissions standards did not qualify for a federal income tax exemption for institutions "organized and operated exclusively for religious, charitable, . . . or educational purposes."79 Reaching beyond the statutory text itself, the Court reasoned that the exemption was based on public services of value to society. It found that this purpose required denying the exemption to any organizations whose activities were "contrary to a fundamental public policy."80 Citing Brown v. Board of Education," the Court noted that "racial discrimination in education violates a most fundamental national public policy, as well as rights of individuals." 82 Even though the Congress that passed the original tax exemption statute probably did not contemplate future developments in the law against racial segregation, the Court's interpretation of the statute was intended to mirror standards of nondiscrimination embedded in the contemporary legal culture. ${ }^{83}$

If Bob Jones illustrates how constitutional norms act as background norms when judges interpret statutes, Chevron U.S.A., Inc. v. Natural Resources Defense Council, Inc., ${ }^{84}$ a 1984 Supreme Court decision, illustrates how constitutional norms can perform an analogous function for statutory interpretation by administrative agencies. Chevron endorsed substantial deference to agency interpretation of statutes by holding that, absent discernible congressional intent, judges may decide only whether the agency's view is reasonable, not whether it is "appropriate." 85 And when judges defer to agencies, they defer to inter-

provides the backdrop against which statutes are written and interpreted, and it furnishes the basic assumptions of interpretation"); White, Law as Language: Reading Law and Reading Literature, 60 TEX. L. REV. 415,435 (1982) (interpreted text "must be fit together with other texts and with the rest of the culture to make what we call a field or body of law").

78. 461 U.S. 574 (1983).

79. I.R.C. \& 501(c)(3) (1988).

80. 461 U.S. at 592.

81. 347 U.S. 483 (1954).

82. 461 U.S. at 593.

83. See generally Eskridge, supra note 74, at 1034-36 (public policy against racial segregation provided background context for interpreting statute in Bob Jones); Eskridge \& Frickey, supra note 77, at 343-44 (similar). The same norm against racial discrimination also guided the Court's decision in Patterson v. McLean Credit Union, 109 S. Ct. 2363 (1989), in which the Court declined to overrule its interpretation of 42 U.S.C. $\S 1981$ in Runyon v. McCrary, 427 U.S. 160 (1976). See 109 S. Ct. at 2371 (referring to "our society's deep commitment to the eradication of discrimination based on a person's race or the color of his or her skin"); id. at 2380 (Brennan, J., concurring in part and dissenting in part) (similar); see also Jones v. Alfred H. Mayer Co., 392 U.S. 409 (1968); cf. Pennhurst State School \& Hosp. v. Halderman, 451 U.S. 1,17 (1981) (background norm based on notions of federalism: "[n]f Congress intends to impose a condition on the grant of federal moneys, it must do so unambiguously. By insisting that Congress speak with a clear voice, we enable the States to exercise their choice knowingly, cognizant of the consequences of their participation." (citation omitted)).

84. 467 U.S. 837 (1984).

85. Id. at 842-43 ("If the intent of Congress is clear, that is the end of the matter; for the court, as well as the agency, must give effect to the unambiguously expressed intent of Congress. If, however, the court determines Congress has not directly addressed the precise question at issue, the court does not simply impose its own construction on the statute . . . as would be necessary in the absence of an administrative interpretation. Rather, if the statute is silent or ambiguous with respect to the specific issue, the question 
pretations that are very likely to reflect, even if at an unspoken level, the contemporary legal culture, which inevitably includes its constitutional law. ${ }^{86}$

An outwardly different understanding of the canon-but one that is just the flip side of the view that constitutional norms serve as the background for subconstitutional interpretation-is to characterize its application as the "underenforcement" of constitutional norms for prudential reasons. Institutional constraints, especially the judiciary's sensitivity to its limited factfinding capability and attenuated electoral responsibility, make courts reluctant to issue a constitutional command to the political branches of government. ${ }^{87}$ Even if such a command clearly would reflect an established constitutional norm, courts can sometimes vindicate that norm less intrusively, and thus perhaps more justifiably, through the indirect route of statutory interpretation. ${ }^{88}$ Many such prudential considerations defy generalization, while others can be collected in bodies of doctrine-the political question ${ }^{89}$ and standing doctrines come to mind-that tend to limit judicial review.

Indeed, the issue presented in Bob Jones could easily have arisen in litigation in which the identity of the parties or the particular facts would prompt the Court to deny constitutional relief, perhaps based on standing or state action requirements. ${ }^{90}$ That these constitutional norms are real in spite of underenforcement in some cases is apparent in the fact that these prudential concerns operate only interstitially. The Court in Bob Jones clearly took seriously the constitutional doubt that would have arisen if the Internal Revenue Code were

for the court is whether the agency's answer is based on a permissible construction of the statute." (footnotes omitted)); $c f$. INS v. Cardoza-Fonseca, 480 U.S. 421, 446-48 (1987) (courts should not defer to agency interpretations on pure questions of law but only on mixed questions of law and fact).

86. Cf. Aleinikoff, Updating Statutory Interpretation, 87 MICH. L. REV. 20, $42-46$ (1988) (Chevron's rule of substantial deference to agency interpretation provides major route for updating statutes because agency interpretations are likely to reflect current policy considerations more than they reflect original intent of legislature).

87. See Sunstein, supra note 77, at 468 (courts reluctant to act with "vigor appropriate to governmental bodies with a better democratic and policymaking pedigree"); see also Sager, Fair Measure: The Legal Status of Underenforced Constitutional Norms, 91 HARV. L. REV. 1212, 1214 (1978) ("important difference between a true constitutional conception and the judicially formulated construct is that the judicial construct may be truncated for reasons which are based not upon analysis of the constitutional concept but upon various concerns of the Court about its institutional role").

88. This view addresses Judge Posner's objection to the judge-made "penumbra" around the Constitution. See supra note 75.

89. See Sager, supra note 87 , at 1224 (political question doctrine rests on distinction "between a determination that there exist decisive reasons for the judiciary to decline to apply a norm of the Constitution to a given set of facts and a determination that the norm in question does not reach that set of facts").

90. The Court noted that its reading of the statute eliminated any need to address arguments by many of the amici curiae that it would be unconstitutional for the government to read the Internal Revenue Code as the private schools had urged. 461 U.S. at 599 n.24. On the standing questions raised by those arguments, the Court found one year later, in Allen v. Wright, 468 U.S. 737 (1984), that parents of Black children who were attending public schools undergoing desegregation in seven states lacked standing to sue the federal government to force it tojdeny tax exemptions to racially segregated private schools that were created or expanded in their communities during that period. 
interpreted to permit the tax exemption. ${ }^{91}$ Acceptance of the background constitutional norm of racial equality as part of mainstream public law is abundantly clear from other cases, among them Brown, in which the Court had to first invent and then apply such a constitutional norm explicitly for lack of any subconstitutional escape hatch. ${ }^{92}$

\section{B. The Emergence of Phantom Norm Decisionmaking in Immigration Law}

There is nothing wrong with borrowing constitutional norms to interpret statutes, but in choosing those norms courts must exercise care. I will try in the rest of Part II and in Part III to review an array of immigration cases decided in the past fifty years to show that immigration law has come to represent an aberrational form of the typical relationship between constitutional and subconstitutional law exemplified by Bob Jones. In immigration law, the "constitutional" norms that actually inform statutory interpretation-which are norms borrowed from public norms generally-conflict with the expressly articulated constitutional norm-unreviewable plenary power. The former are "phantom" rather than "real" constitutional norms in the sense that they do not serve the first function of "constitutional" norms-namely, direct application to constitutional issues raised in immigration cases. In fact, the plenary power cases provide, as a matter of explicit constitutional theory, that the immigration context is different, and that therefore we cannot directly apply mainstream constitutional norms in immigration cases. But "phantom constitutional norms" are "constitutional" in the sense that they, having been at least seriously entertained as a constitutional argument and in many cases actually adopted as an expressly constitutional decision in other areas of law, then carry over to immigration cases, where they are substantial enough to serve the limited function of informing interpretation of immigration statutes and other subconstitutional texts. Or, to use an image from the physical sciences, they have enough gravitational force to exercise a pull on these other sources of law. ${ }^{93}$ In this context, phantom norms produce results that are much more sympathetic to aliens than the results that would follow from the interpretation of statutes in

91. See 461 U.S. at 599 n.24 (citing two then-recent leading cases invoking this interpretive canon to avoid constitutional doubts: United States v. Clark, 445 U.S. 23, 27 (1980), and NLRB v. Catholic Bishop, 440 U.S. 490, 504 (1979)).

92. That this norm is "real" is also clear from cases holding that Congress may enforce these norms, even against private activity, under section 5 of the Fourteenth Amendment or under Congress' power to provide for the "general Welfare," U.S. CoNST. art. I, \& 8, cl. 1. See, e.g., Metro Broadcasting, Inc. v. FCC, 110 S. Ct. 2997 (1990); Fullilove v. Klutznick, 448 U.S. 448, 472 (1980). Similar reasoning underlies the interpretation given Title VII, 42 U.S.C. \$ 2000 e (1988), in United Steelworkers v. Weber, 443 U.S. 193, 200-08 (1979). For a discussion of the use of background norms to interpret Title VII in Weber and Johnson v. Transportation Agency, 480 U.S. 616, 627-42 (1987), which used similar reasoning to uphold affirmative action programs for women, see Eskridge, supra note 74, at 1033-34.

93. See Eskridge, supra note 74 , at 1018-19. 
light of the expressly applicable constitutional immigration law based on plenary power.

The emergence of these more sympathetic results is easier to understand if we look beyond the field of "immigration law," defined as the law of admission and expulsion of aliens. Once we expand our inquiry to include the more general law of aliens' rights and obligations, the force of the plenary power doctrine diminishes considerably. In contrast to the harshness of classical immigration law, a long line of Supreme Court decisions has afforded a measure of protection to aliens that much more closely resembles the substantive and procedural rights of individuals in mainstream public law. By use of the term "mainstream," I do not mean to suggest that there is a set of transcendent constitutional norms "out there" that do not vary according to the type of case or the nature of the power that Congress is asserting. The Court clearly adopts constitutional norms with the highest degreee of sensitivity to substantive context. My point is a more limited one-namely, that in all of these other contexts involving aliens the Court has adopted approaches that, despite variations among them, consistently conflict with the begrudging attitude toward aliens reflected in the plenary power doctrine. ${ }^{94}$

A seminal case in this regard is Yick Wo v. Hopkins, decided by the Court in 1886, which held that the Constitution protects all individuals inside the United States, including aliens, from invidious discrimination at state hands. ${ }^{95}$ The classification in question was not based on alienage per se, but rather was an ostensibly race-neutral regulation that was enforced so as to make it impossible for aliens of Chinese descent to operate laundries in San Francisco. The basic point of Yick Wo-and one that stands in sharp contrast to the possible implications of the Chinese Exclusion Case-is that aliens, at least those lawfully present in the United States, are within the constitutional fold. ${ }^{96}$ Another seminal case is Wong Wing v. United States, ${ }^{97}$ decided by the Court in 1896, which involved a statute providing that any Chinese national whom executive officials found to be in the United States illegally "shall be imprisoned at hard labor." 98 The Court, only three years after the Chinese Exclusion Case, relied on Yick Wo in holding that an alien is entitled to the full range of protections afforded by the Fifth and Sixth Amendments, and specifically that

94. I also do not intend to amalgamate artificially all other constitutional law into a unitary whole. Other areas of public law, among them federal Indian law and foreign affairs, to name only two, similarly stand outside the mainstream. But it is probably more accurate to say that those other areas are also isolated than it is to suggest that there is no such thing as "mainstream" constitutional law.

95. 118 U.S. 356, 369 (1886). The Supreme Court cited Yick Wo with approval in later cases. For example, in Johnson v. Eisentrager, 339 U.S. 763, 770 (1950), the Court said that "[t]he alien, to whom the United States has been traditionally hospitable, has been accorded a generous and ascending scale of rights as he increases his identity with our society."

96. See 118 U.S. at 369 ("The Fourteenth Amendment to the Constitution is not confined to the protection of citizens.").

97. 163 U.S. 228 (1896).

98. Act of May 5, 1892, ch. $60, \S 6,27$ Stat. 25 . 
"a judicial trial to establish the guilt of the accused" would be required before such "infamous punishment" could be imposed. ${ }^{99}$ Similarly, in the 1931 case, Russian Volunteer Fleet v. United States, the Court relied on Yick Wo and Wong Wing, among other cases, in applying the takings clause of the Fifth Amendment to benefit non-enemy aliens present within United States territory. ${ }^{100}$

By the 1950's, aliens' rights decisions beyond the scope of immigration law already conflicted with assumptions implicit in the plenary power doctrine. ${ }^{101}$ As Alex Aleinikoff has pointed out, the Yick Wo approach differs from classical immigration law's model of aliens' rights, which was a "membership model of citizenship and alienage" that responded to the perceived need to draw a line between those who belong to the "national community" and those who do not. ${ }^{102}$ The legacy of Yick Wo represents a different model based on "a notion of fundamental human rights that protects individuals regardless of their status." 103 This model's emergence, as Peter Schuck has noted, is attributable to fundamental cultural changes fostering the growth of the values that he calls "communitarian." 104 More specifically, the Yick Wo model draws sustenance from developments elsewhere in the constitutional law of individual rights and liberties, including the landmark 1954 decision in Brown v. Board of Education. ${ }^{105}$

These decisions, both in the law of aliens' rights and in the law of individual rights generally, have never fully coalesced into a coherent and comprehensive body of doctrine to guide courts' admission and expulsion decisions, and thus have never offered a fully textured alternative to the plenary power doctrine. Nor have they ever suggested that aliens be guaranteed the full range and force of constitutional protections enjoyed by citizens. But Yick Wo and its progeny took these constitutional claims seriously, in contrast to the cavalier treatment of constitutional claims in immigration law. Moreover, lawyers and judges, whether justified or not, have in fact relied on the values and the approach manifest in Yick Wo, and this reliance has influenced the course of

99. 163 U.S. at 237.

100. 282 U.S. 481,489 (1931).

101. Yick Wo's more recent progeny are discussed infra text accompanying notes 194-217.

102. See Aleinikoff, Citizens, Aliens, Membership and the Constitution, 7 CONST. COMMENTARY 9, 10 (1990) [hereinafter Aleinikoff, Membership] ("Immigration policy, conceived of as membership rules, is thought to lie at the core of national self-determination and self-definition."); see also Aleinikoff, Federal Regulation of Aliens and the Constitution, 83 AM. J. INT'L L. 862, 864 (1989) [hereinafter Aleinikoff, Federal Regulation]; Bosniak, Exclusion and Membership: The Dual Identity of the Undocumented Worker Under United States Law, 1988 WIS. L. REV. 955, 967-77.

103. Aleinikoff, Membership, supra note 102, at 19; see also Martin, Due Process and Membership in the National Community: Political Asylum and Beyond, 44 U. PITT. L. REV, 165, 180 (1983) ("TA]nyone inspired by the Yick Wo tradition-a certain pride in the broad reach of our Constitution's protections-cannot rest content with Knauff-Mezei nor with the pretense that excludable aliens really are not here."),

104. See Schuck, supra note 6 , at 34-53.

105. 347 U.S. 483 (1954). 
immigration law. For example, Wong Wing's application of constitutional protections to any "punishment" of an alien explains the persistence of the argument, first heard no later than Fong Yue Ting ${ }^{106}$ and since then often reattempted in vain, ${ }^{107}$ that deportation is punishment. ${ }^{108}$ In short, Yick Wo and its progeny, as well as other developments in the law of individual rights, have provided the normative foundation for results at odds with strict application of the plenary power doctrine.

The centrality of phantom norm decisionmaking in immigration law gradually emerged through several Supreme Court decisions from roughly the same period as Mezei, Knauff, and Harisiades. Their unifying characteristic is their propensity to use phantom norm constitutional reasoning to reach subconstitutional outcomes favorable to aliens. They differ from each other only in the boldness of their phantom norm decisionmaking.

The earliest of these cases is Bridges v. Wixon, ${ }^{109}$ a 1945 decision that arose from the government's efforts to deport the union activist Harry Bridges. The pertinent deportation ground covered past membership or affiliation with "any organization, association, society, or group, that believes in, advises, advocates, or teaches ... the overthrow by force of violence of the Government of the United States." 110 The Court, reading the statute, held that Bridges was not subject to deportation. ${ }^{11}$ This was unremarkable; earlier decisions had relied on subconstitutional grounds to reach results favorable to aliens. ${ }^{112}$ One way to understand the case, however, is to focus on the potentially constitutional character of the reasoning in Justice Douglas' majority opinion. That opinion

106. As discussed supra text accompanying note 35, Fong Yue Ting v. United States, 149 U.S. 698 (1893), distinguished Yick Wo in reaching this conclusion. Fong Yue Ting, 149 U.S. at 725.

107. See Carlson v. Landon, 342 U.S. 524, 537 (1952) ("Deportation is not a criminal proceeding and has never been held to be punishment."); Mahler v. Eby, 264 U.S. 32, 39 (1924); United States ex rel. Bilokumsky v. Tod, 263 U.S. 149, 154 (1923); Bugajewitz v. Adams, 228 U.S. 585, 591 (1913) (Holmes, J.) (deportation is not "a punishment; it is simply a refusal by the Government to harbor persons whom it does not want").

108. Aliens have also attempted to characterize deportation as punishment in order to challenge certain deportation grounds as unconstitutional ex post facto laws. See Harisiades v. Shaughnessy, 342 U.S. 580, 593-95 (1952), discussed supra text accompanying notes 63-69, and other sources cited supra note 69.

109. 326 U.S. 135 (1945).

110. Alien Registration Act of 1940 , ch. $439, \S 23,54$ Stat. 670,671 .

111. The Court first interpreted "affiliation" narrowly, saying that the term required more than the mere sympathy or cooperation that the government had shown in Bridges. 326 U.S. at 143-44 ("Whether intermittent or repeated, the act or acts tending to prove 'affiliation' must be of that quality which indicates an adherence to or a furtherance of the purposes or objectives of the proscribed organization as distinguished from mere cooperation with it in lawful activities. The act or acts must evidence a working alliance to bring the program to fruition."). It then held that the finding of "membership" that triggered deportation had rested on unsworn statements that were inadmissible under the government's own regulations. Id. at 149-56.

112. See, e.g., Gegiow v. Uhl, 239 U.S. 3, 9-10 (1915) (Commissioner of Immigration exceeded his statutory authority in basing "public charge" determination on local labor market only); Chin Yow v. United States, 208 U.S. 8, 12 (1908) (returning resident of Chinese descent not given adequate opportunity to prove United States citizenship: "If one alleging himself to be a citizen is not allowed a chance to establish his right in the mode provided by those statutes, although that mode is intended to be exclusive, the statutes cannot be taken to require him to be turned back without more."). 
focused on deportation's harsh consequences, ${ }^{113}$ an argument which lawyers and judges had previously used in asserting the constitutional claim that deportation should be treated like criminal punishment. ${ }^{114}$ Justice Murphy's concurrence made clear this theme's constitutional dimensions by going further and relying on the same set of harsh consequences to declare that " $[t]$ he unconstitutionality of the statute in issue and the invalidity of the proceeding brought pursuant thereto are obvious." 115 Although the Court had consistently rejected that view as a constitutional matter, ${ }^{116}$ it had sufficient gravitational force to affect the interpretation of the statute in Bridges.

No single decision established the method of using statutory interpretation to offset the disadvantaged position of aliens in constitutional immigration law, but several cases taken together trace the development of a statutory-interpretation pattern. The next key case in this progression is Fong Haw Tan v. Phelan. ${ }^{117}$ In Fong Haw Tan, a 1948 decision, the Court was confronted with the issue of the proper construction of a statutory deportation ground. The statute in question provided for the deportation of any alien "sentenced [to imprisonment] more than once" for committing crimes involving moral turpitude. ${ }^{118}$ Writing for a unanimous Court, Justice Douglas again focused on deportation's harsh consequences. ${ }^{119}$ Even though those consequences had never led a court to sustain a constitutional challenge to a substantive deportation ground, Justice Douglas declared, as a general interpretive rule, that courts must read ambiguous deportation statutes or regulations in the light most favorable to the alien. ${ }^{120}$

113. Bridges, 326 U.S. at 147 ("[Tt must be remembered that although deportation technically is not criminal punishment, it may nevertheless visit as great a hardship as the deprivation of the right to pursue a vocation or a calling" (citing, inter alia, Ng Fung Ho v. White, 259 U.S. 276, 284 (1922))); see also id. at 154 ("Though deportation is not technically a criminal proceeding, it visits a great hardship on the individual and deprives him of the right to stay and live and work in this land of freedom. That deportation is a penalty-at times a most serious one-cannot be doubted.").

114. See supra text accompanying notes 106-08.

115. Bridges, 326 U.S. at 160 (Murphy, J., concurring).

116. See supra text accompanying note 107 .

117. 333 U.S. 6, 7 (1948).

118. Immigration Act of 1917 , ch. $29, \S 19$ (a), 39 Stat. 874,889 (current version codified at 8 U.S.C. $\S 155(a)(1988))$.

119. 333 U.S. at 10 ("We resolve the doubts in favor of that construction because deportation is a drastic measure and at times the equivalent of banishment or exile. ... It is the forfeiture for misconduct of a residence in this country. Such a forfeiture is a penalty. To construe this statutory provision less generously to the alien might find support in logic. But since the stakes are considerable for the individual, we will not assume that Congress meant to trench on his freedom beyond that which is required by the narrowest of several possible meanings of the words used." (citation omitted)).

120. More recent applications of this rule include INS v. Cardoza-Fonseca, 480 U.S. 421, 449 (1987) (referring to "longstanding principle of construing any lingering ambiguities in deportation statutes in favor of the alien"); INS v. Errico, 385 U.S. 214, 225 (1966); Costello v. INS, 376 U.S. 120, 128 (1964); Bonetti v. Rogers, 356 U.S. 691,699 (1958); Barber v. Gonzales, 347 U.S. 637, $642-43$ (1954). Similar canons of construction, discussion of which is beyond the scope of this article, ameliorate the inequalities associated with treaties between the federal government and Indian tribes. See generally F. COHEN, HANDBOOK OF FEDERAL INDIAN LAW 221-25 (R. Strickland ed. 1982); D. GETCHES \& C. WILKINSON, FEDERAL INDIAN LAW: CASES AND MATERIALS 214-17 (2d ed. 1986); C. WIIKINSON, AMERICAN INDIANS, TIME, AND THE LAW 46-52 (1987); Wilkinson \& Volkman, Judicial Review of Indian Treaty Abrogation: "As Long As 
In 1950, the Court decided Wong Yang Sung v. McGrath. ${ }^{121}$ At that time, the statute and regulations let the same corps of immigration inspectors investigate some deportation cases and preside over deportation proceedings in others. They could preside over cases in which they had performed prosecutorial tasks, though not over cases that they had investigated. ${ }^{122}$ The combination of adjudicative and prosecutorial roles conflicted with the Administrative Procedure Act's separation-of-functions provisions, ${ }^{123}$ but the APA applied by its terms only to "adjudication required by statute." 124 Was a deportation hearing "required by statute"? The Court said that it was, even though the statute contained no express requirement, reasoning that construing it otherwise "might again bring it into constitutional jeopardy."125

That holding ${ }^{126}$ belies Wong Yang Sung's complexity. Deportation with no hearing at all was almost certainly unconstitutional. This constitutional norm, having already been established in Yamataya $v$. Fisher, was not a phantom. ${ }^{127}$ Another constitutional norm, however, also played a role in reaching the subconstitutional conclusion that the APA applied. ${ }^{128}$ This second norm, foreign to immigration law, would have required as a constitutional due process matter, and contrary to the immigration statute without the APA, that the deportation proceedings be conducted by an independent hearing examiner who had not acted as a prosecutor. That this constitutional norm was a phantom finds confirmation five years later in Marcello v. Bonds, ${ }^{129}$ which rejected a due process challenge to similar separation-of-functions provisions in the 1952 immigration statute. ${ }^{130}$

Water Flows, or Grass Grows Upon the Earth"-How Long a Time Is That?, 63 CALIF. L. REV. 601 (1975); Note, The Canons of Indian Treaty and Statutory Construction: A Proposal for Codification, 17 U. MICH. J. LEGAL RES. 681 (1984). For the view that these sympathetic canons may not always have an ameliorative effect, see Frickey, Scholarship, Pedagogy, and Federal Indian Law, 87 MICH. L. REv. 1199, 1208-09 (1988).

121. 339 U.S. 33 (1950).

122. Immigration Act of 1917, ch. 29, $\S 16-17,39$ Stat. 874, 885-87, repealed by Immigration and Nationality Act of 1952, ch. 477, § 403(a)(13), 66 Stat. 163, 279. The then-governing regulations are summarized in Wong Yang Sung, 339 U.S. at 45-46. 1010).

123. Act of 1946, ch. 324, $\S \S$ (c), 11, 60 Stat. 237, 240, 244 (current version at 5 U.S.C. $\S \S 1004(c)$,

124. Act of 1946 , ch. $324, \S 5,60$ Stat. 237,240 (current version codified at 5 U.S.C. $\S 1004$ ).

125. 339 U.S. at 50.

126. See id. at 49 ("the difficulty with any argument premised on the proposition that the deportation statute does not require a hearing is that, without such hearing, there would be no constitutional authority for deportation"); $i d$. at 49-50 ("It was under compulsion of the Constitution that this Court long ago held that an antecedent deportation statute must provide a hearing at least for aliens who had not entered clandestinely and who had been here some time even if illegally.") (citing Yamataya v. Fisher, 189 U.S. 86 (1903)).

127. 189 U.S. 86 (1903), discussed supra text accompanying notes $42-44$.

128. See id. at $48-51$.

129. 349 U.S. 302 (1955).

130. Id. at 311 ("The contention is without substance when considered against the long-standing practice in deportation proceedings, judicially approved in numerous decisions in the federal courts, and against the special considerations applicable to deportation which the Congress may take into account in exercising its particularly broad discretion in immigration matters."). $C f$. Withrow v. Larkin, 421 U.S. 35, 46-55 (1975) (rejecting due process challenge against board of medical examiners); Richardson v. Perales, 
In the end, Wong Yang Sung's interpretation of the APA reflects two constitutional norms, one "real" - deportation without a hearing violates procedural due process-and one "phantom"-a deportation hearing before an official who mixes functions violates procedural due process. That case represents a further step in the development of phantom norm decisionmaking because its language is bolder than that found in Bridges or in Fong Haw Tan. In those two earlier cases, the Court's decision had compensated only in very general fashion for the relatively disadvantageous position of aliens in immigration law. Viewing only those two decisions, one could argue that they do not reflect phantom norms at all. They might simply be statutory interpretation cases that favor aliens, which we could explain without necessarily suggesting that they are the subconstitutional reflection of constitutional norms that the Court would not apply directly. But in Wong Yang Sung, the Court's constitutional reasoning, based in part on a phantom norm, was more specific to the question presented. This makes it harder to avoid characterizing the decision as a direct challenge to the result that the Court would have reached had it applied the "real" constitutional norm, which permitted combination of adjudicative, investigative, and prosecutorial functions.

Phantom norm decisionmaking reached maturity in Kwong Hai Chew v. Colding, ${ }^{131}$ a 1953 case that the Supreme Court decided five weeks before $M e z e i$, and which, like Mezei, concerned a returning permanent resident. After a five-month voyage as a seaman aboard a United States merchant ship, Chew sought to reenter the country. The government denied him entry, claiming it was "prejudicial to the public interest," and relying on the same enactments used to exclude Mezei. ${ }^{132}$ The regulations further provided that such aliens could be excluded without a hearing where, as in Mezei's case, disclosure of the specific grounds for exclusion also would be "prejudicial to the public inter-

402 U.S. 389, 408-10 (1971) (rejecting due process challenge based on lack of separation of functions in social security disability hearings). Marcello arose after an appropriations rider had legislatively overruled Wong Yang Sung by expressly stating that the APA did not cover "exclusion or expulsion" of aliens. Act of Sep. 27, 1950, ch. 1052, $\S 1,64$ Stat. 1044, 1048. Marcello decided that the 1952 Immigration and Nationality Act continued this limitation on APA coverage; enforcement officials could also preside over hearings, but not do both in the same case. The Court then had to decide if the statute, so construed, violated constitutional due process, and the Court held without extended discussion that it did not. Cf. Marcello, 349 U.S. at 315-19 (Black, J., dissenting) (would read statute differently, so would not reach due process issue); Wong Yang Sung, 339 U.S. at 53 (Reed, J., dissenting) ("In this case no one questions the constitutionality of the hearing Wong received ....".). The constitutional issues in Marcello and Wong Yang Sung were similar but not identical to each other. The 1917 Act had separated adjudicative from investigative functions but not from prosecutorial functions in the same case. Under the 1952 law, hearing officers with either investigative or prosecutorial functions could not preside over the same case, though they remained under the supervision of officials with investigative and prosecuting functions. INA $\$ 242(\mathrm{~b}), 8$ U.S.C. § 1252(b) (1988). To see Wong Yang Sung as a statutory decision and Marcello as a constitutional one helps answer the question posed by Peter Schuck, "[H] Wong Yang Sung?" Schuck, supra note 6, at 33 (Wong Yang Sung was a constitutional decision). See also Wong Yang Sung, 339 U.S. at 30-34, 72-73. For background from a first-hand perspective, see Rawitz, From Wong Yang Sung to Black Robes, 65 INTERPRETER RELEASES 453 (1989).

131. 344 U.S. 590 (1953).

132. Id. at 591-92; 8 C.F.R. $\$ 175.53$ (1953). 
est."133 Subconstitutionally, Chew argued that the regulation did not apply to him. Alternatively, he made the constitutional claim that excluding him without a hearing would deny his procedural due process rights as a returning permanent resident.

The Court's holding that the summary exclusion regulation did not apply to Chew was subconstitutional. ${ }^{134}$ This was a highly questionable reading of the regulation's text that Louis Henkin rightly called one of the Court's "feats of creative interpretation" in immigration law. ${ }^{135}$ The Court was careful to disclaim reaching the constitutional issue ${ }^{136}$ but as Mezei soon confirmed, Chew's underlying reasoning was unmistakably constitutional. ${ }^{137}$ The opinion's language, especially its references to Yick Wo, Wong Yang Sung, and Justice Murphy's concurring opinion in Bridges, ${ }^{138}$ suggests that the Court favored a constitutional norm of procedural due process for returning permanent residents like Chew, even if the statute and regulations, by applying the reentry doctrine to a temporary departure, treated them no better than first-time entrants. ${ }^{139}$ In 1953, however, any such constitutional norm was a phantom because, as the Court would soon confirm in Mezei, aliens seeking admission could not challenge immigration law on explicitly constitutional grounds. At the same time, the phantom norm had enough gravitational force.to exercise a pull on the Court's interpretation of the regulation. The Chew opinion thus subconstitutionally reached the result that the expressly constitutional holding in Mezei seemed to preclude.

133. Chew, 344 U.S. at 591-92; 8 C.F.R. $\S 175.57$ (b) (1953).

134. 344 U.S. at 600 ("Section 175.57(b)'s authorization of the denial of hearings raises no constitutional conflict if limited to 'excludable' aliens who are not within the protection of the Fifth Amendment.").

135. Henkin, The Constitution and the United States Sovereignty: A Century of Chinese Exclusion and Its Progeny, 100 HARV. L. REV. 853, 861 n.40 (1987).

136. Chew, 344 U.S. at 602 ("We do not reach the issue as to what would be the constitutional status of 8 CFR $\& 175.57($ b) if it were interpreted as denying to petitioner all opportunity for a hearing."). See also Mezei, 345 U.S. at 214 (in Chew, "to escape constitutional conflict we held the administrative regulations authorizing exclusion without hearing in certain security cases inapplicable to aliens so protected by the Fifth Amendment") (citing Chew, 344 U.S. at 600).

137. See Mezei, 345 U.S. at 213 ("a lawful resident alien may not captiously be deprived of his constitutional rights to procedural due process") (citing Chew, 344 U.S. at 601). The Court further confirmed the constitutional character of the reasoning of Chew in two important cases that Part II.C discusses. See Landon v. Plasencia, 459 U.S. 21, 33 (1982) ("the rationale [in Chew] was one of constitutional law"); Rosenberg v. Fleuti, 374 U.S. 449, 460 (1963) ("the returning resident alien is entitled as a matter of due process to a hearing on the charges underlying any attempt to exclude him") (citing Chew, 344 U.S. 590).

138. 344 U.S. at 596-98 nn.5-7.

139. "For purposes of his constitutional right to due process, we assimilate petitioner's status to that of an alien continuously residing and physically present in the United States." Id. at 596. Mezei distinguished Chew by remarking that Chew had "with full security clearance and documentation pursued his vocation for four months aboard an American ship," while Mezei had "apparently without authorization or reentry papers, simply left the United States and remained behind the Iron Curtain for 19 months." Mezei, 345 U.S. at 214. Scholarship from that era raised similar concerns about the treatment of returning permanent residents. See, e.g., Hart, supra note 48, at 1392-93; Hesse, The Constitutional Status of the Lawfully Admitted Permanent Resident Alien: The Inherent Limits of the Power to Expel, 69 YALE L.J. 262 (1959); Hesse, The Constitutional Status of the Lawfully Admitted Permanent Resident Alien: The Pre-1917 Cases, 68 YALE L.J. 1578 (1959). 
Another example of the influence of phantom norms is the Court's 1966 decision in Woodby v. Immigration and Naturalization Service (INS). ${ }^{140}$ There, a majority held that the government must show deportability by "clear, unequivocal, and convincing evidence," rather than by a "preponderance of the evidence" as the government had urged. ${ }^{141}$ While the Court's opinion claimed to turn solely on a statute, the Court, as in Chew, relied heavily on constitutional considerations of the kind that the Court would recognize in the procedural due process revolution that began a few years afterwards with the Court's 1970 decision in Goldberg v. Kelly. ${ }^{142}$ Indeed, on at least one later occasion, the Court characterized Woodby as a constitutional decision based on notions of fundamental fairness. ${ }^{143}$ In particular, the Woodby Court noted the harsh consequences of deportation and that many permanent residents had strong ties to this country. ${ }^{144}$ Guided by a strong constitutional due process norm, the Court interpreted the immigration statute to require more procedural due process than was available in an ordinary civil proceeding. As in Chew, that norm was a phantom. ${ }^{145}$ Earlier cases starting with Yamataya ${ }^{146}$ had suggested some procedural due process minimum, but in fact the strictest real norm had imposed only the most modest requirements that have never begun to approach the constitutional protections of criminal procedure. ${ }^{147}$

140. 385 U.S. 276 (1966). David Martin has suggested that both Fong Haw Tan, D. MARTIN, supra note 9 , at 19 , and Woodby, id. at $25-27$, were attempts to compensate for the relative unavailability of judicial review in classical immigration law.

141. 385 U.S. at 281-84. The government relied mainly on references in the statute to "reasonable, substantial, and probative evidence." INA §§ 106(a)(4), 242(b)(4), 8 U.S.C. §§ 1105a(a)(4), 1252(b)(4) (1988). The majority interpreted this language to set the standard for judicial review, not for the deportation proceedings in the first instance. Justice Clark, joined in dissent by Justice Harlan, would have decided for the government based on the language and legislative history of INA $\$ 242$ (b). 385 U.S. at 287-91 (Clark, J., dissenting). $C f$. Kungys v. United States, 485 U.S. 759, 772 (1988) (denaturalization proceedings); Schneiderman v. United States, 320 U.S. 118, 125 (1940) (same).

142. 397 U.S. 254 (1970). See also Mathews v. Eldridge, 424 U.S. 319 (1976); Perry v. Sinderman, 408 U.S. 593 (1972); Board of Regents v. Roth, 408 U.S. 564 (1972).

143. See Santosky v. Kramer, 455 U.S. 745, 756, 759 (1982). But cf. Vance v. Terrazas, 444 U.S. 252, 266 (1980) (Woodby did not purport to be constitutional holding). The Immigration Marriage Fraud Amendments of 1986, Pub. L. No. 99-639, 100 Stat. 3537, may force courts to decide what standard of proof the Constitution requires. INA \& $216(\mathrm{~b})(2), 8$ U.S.C. $\$ 1186 \mathrm{a}(\mathrm{b})(2)(1988)$, gives the INS the burden to prove by a mere preponderance of the evidence that an alien in deportation is not entitled to the conditional resident status created by IMFA.

144. 385 U.S. at 285 ("To be sure, a deportation proceeding is not a criminal prosecution. . . . But it does not syllogistically follow that a person may be banished from this country upon no higher degree of proof than applies in a negligence case. This Court has not closed its eyes to the drastic deprivations that may follow when a resident of this country is compelled by our Government to forsake all the bonds formed here and go to a foreign land where he often has no contemporary identification.").

145. See Marcello v. Bonds, 349 U.S. 302 (1955), discussed supra text accompanying notes 129-30. See generally Developments in the Law-Immigration and Nationality, 66 HARV. L. REV. 643, 680-82, 69095 (1953).

146. Yamataya, 189 U.S. 86 (1903), discussed supra text accompanying notes $42-44$.

147. Leading cases rejecting the argument that deportation amounts to criminal punishment are cited supra note 107. 
A pattern emerges from Bridges, Fong Haw Tan, Wong Yang Sung, Chew, and Woodby. ${ }^{148}$ In Bridges, Fong Haw Tan, and Wong Yang Sung, the Court allowed phantom constitutional norms to guide statutory interpretation by reading statutes in favor of aliens. In Chew and Woodby, phantom norm decisionmaking produced results that directly conflicted with those that the Court would have reached by applying the "real" constitutional norms. ${ }^{149}$ Further evidence of the sway of phantom norms is found in the fact that dissenting opinions also relied on such norms. In Knauff, for example, Justices Frankfurter and Jackson did not criticize the majority for its constitutional holding. Rather, they urged the Court to interpret the ambiguous statute against summary exclusion, an interpretation that would have been in accordance with a phantom constitutional norm of procedural due process in exclusion. ${ }^{150}$

These phantom norm decisions represent an aberrational application of the canon that judges should interpret statutes to avoid constitutional doubts. The usual reason for applying the canon is to avoid defining what the Constitution means with virtually irrevocable finality, and yet to provide a just result. This rationale is valid only when the directly and indirectly applicable constitutional norms are roughly consistent with each other. Where direct and indirect norms harmonize with each other, "underenforced' constitutional norms"151 and

148. Some counterexamples from this period deserve mention. I believe that they do not undermine my basic thesis, since I do not claim that the Court seized every opportunity to interpret subconstitutional texts by relying on a phantom norm, only that enough decisions did so to allow us to identify it as a type of judicial decisionmaking in immigration cases. The Court rejected both subconstitutional and constitutional challenges in at least two other cases from the same general period. In Galvan v. Press, 347 U.S. 522 (1954), Justice Frankfurter first rejected the argument that the deportation ground for Communist Party membership, Internal Security Act of 1950, ch. 1024, § 22, 64 Stat. 987, 1006 (substantially codified at INA $\S 241(a)(6)(C), 8$ U.S.C. $\S 1251(a)(6)(C)(1988))$, should be read to exclude any member not "fully cognizant of the Party's advocacy of violence." 347 U.S. at 528 . He then rejected the constitutional attack on the same statute. Id. at 529-32. See also Jay v. Boyd, 351 U.S. 345, 357 (1956) ("[W]e must adopt the plain meaning of [the suspension of the deportation] statute, however severe the consequences.") (citing Galvan v. Press, 347 U.S. 522, 528 (1954)). A third counterexample is Knauff, where the Court could have taken a statutory approach but did not. See Hart, supra note 48, at 1395 ("the War Brides Act was highly ambiguous on the point in issue of whether exclusion without a hearing was authorized"). Mezei and Harisiades are not counterexamples because subconstitutional solutions would have involved much more strained readings of the applicable statutes or regulations.

149. A similar case in a related area of law is Kent v. Dulles, 357 U.S. 116 (1958), which arose when several United States citizens sued to force the Department of State to issue them passports so that they could travel abroad. While Justice Douglas' reasoning for the majority was based on the constitutional right to travel, the decision was clearly subconstitutional-the Department's regulations, which elicited information on passport applicants' political affiliations, exceeded the scope of its statutory authority. "Since we start with an exercise by an American citizen of an activity included in constitutional protection, we will not readily infer that Congress gave the Secretary of State unbridled discretion to grant or withhold it." Id. at 129. Justice Clark, writing for the four dissenters, disagreed with the majority's reading of congressional intent and would have found that the Department of State acted within its statutory authority. Id. at 130-43 (Clark, J., dissenting). Kent is a phantom norm case like Chew and Woodby in that no tradition of constitutional judicial review of executive decisions regarding passports existed.

150. See United States ex rel. Knauff v. Shaughnessy, 338 U.S. 537, 549-50 (1950) (Frankfurter, J., dissenting); id. at 551-52 (Jackson, J., dissenting).

151. See Sager, supra note 87, at 1213-20; see also Sunstein, supra note 77, at 468 ("courts underenforce many constitutional norms"). 
"constitutional common law" sensibly and justifiably arise. ${ }^{152}$ But neither this reasoning nor this terminology applies where the constitutional norms underlying subconstitutional decisions are phantom norms. This duality of constitutional norms present in immigration law makes Chew and Woodby quite different from Bob Jones and other examples of constitutionally influenced statutory interpretation in mainstream public law.

I recognize that describing norms as "real" is not a simple matter. The "racial equality" norm, for example, is derived from a series of concrete decisions, none of which need be explained that abstractly. If the norm is "real," how do we account for a case like Washington v. Davis, ${ }^{153}$ which established the principle that a finding of unconstitutional race discrimination requires proof of discriminatory purpose in addition to proof of discriminatory effect? In my view, that case represents underenforcement of the norm, though not the particular type of underenforcement represented by avoidance of constitutional issues through statutory interpretation. The Washington v. Davis Court had prudential reasons for its decision; it was responding to perceived limits on the judiciary's institutional capacity to measure unlawful discrimination. While that underenforcement may have been unjustified, and while it may represent a practical retrenchment of race remedies doctrine, ${ }^{154}$ Washington v. Davis and similar cases affirm the basic proscription against racial discrimination. "Norms" are by definition standards of some generality, much broader than the rule laid down in Washington v. Davis. In identifying constitutional norms that courts adopt as background for statutory interpretation, we must accept the degree of generality with which litigants and judges tend to invoke them. As with the state action, standing, and political question doctrines, the interstitial cases in which the norm is not fully enforced do not take away from the existence of the norm against racial discrimination if it can be established from other sources. Indeed, the norm has become so engrained that even a court hostile to civil rights could not plausibly call into question the fundamental principle against racial discrimination that many questioned in all seriousness before Brown.

Unlike the standing or political question doctrines, however, the plenary power doctrine smothers the entire field of immigration law so completely that it is difficult to find the benchmarks of "full enforcement" of real norms. ${ }^{155}$ In 1953 no immigration decisions had established a constitutional norm prohib-

152. See Monaghan, The Supreme Court, 1974 Term-Foreword: Constitutional Common Law, 89 HARV. L. REV. 1 (1975).

153. 426 U.S. 229 (1976).

154. See, e.g., Delgado, On Taking Back Our Civil Rights Promises: When Equality Doesn't Compute, 1989 WIS. L. REV. 579, 583-84.

155. Of the examples offered by William Eskridge of groups-“discrete and insular minorities"-favored by statutory interpretation, only aliens in immigration law cases stand out as unprotected by analogous judicial concern at the constitutional level. See Eskridge, supra note 74, at 1032-34 (1989); see also Frickey, Congressional Intent, Practical Reasoning, and The Dynamic Nature of Federal Indian Law, _ CALIF. L. REV. _ (forthcoming 1990); Sunstein, supra note 77, at 472-73, 483-86. 
iting exclusion of a returning permanent resident without a hearing. If there had been such a case, then Chew, like Bob Jones, might be an example of interpreting a statute to avoid constitutional doubt and thus of underenforcing a real constitutional norm to avoid unnecessary friction between the branches of government. Or more generally, if plenary power were repudiated, subconstitutional immigration cases would look a lot more like subconstitutional race cases. In Chew and Woodby, the majority's sense of what the constitutional law should be in the future guided the Court's interpretation of the statute. The Court could have disposed of the case consistent with the reigning constitutional norm, or it could have replaced the plenary power doctrine with a constitutional norm favorable to aliens. However, the Court was unwilling to adopt either course, and instead adopted the middle ground of interpreting the statute in accordance with a phantom constitutional norm. ${ }^{156}$

\section{Constitutional Change: From Phantom Norms to Real Norms}

In the past twenty-five years, one key aspect of the movement away from classical immigration law has been an increasing acceptance of the view that an alien's constitutional status when challenging immigration statutes should depend on more than just her geographic location. A returning permanent resident, even if outside the United States, typically has ties or a "stake" here that merit more exacting constitutional scrutiny than that available to first-time entrants. ${ }^{157}$ As Chew suggests, the first stage in this development was the emergence of a phantom constitutional norm that recognized a resident alien's stake in this country and served as a guide to further statutory interpretation. Later cases suggest that through phantom norm decisionmaking, subconstitu-

156. When a decision relies on a real constitutional norm to guide statutory interpretation, it need not be as careful to avoid a constitutional pronouncement as a decision, such as $C h e w$, that relies on a phantom norm. A good illustration is Yamataya v. Fisher, 189 U.S. 86 (1903), discussed supra text accompanying notes 42-44. Yamataya is usually read as a constitutional decision. See, e.g., Shaughnessy v. United States ex rel. Mezei, 345 U.S. 206, 212 (1953) (Yamataya established that "aliens who have once passed through our gates, even illegally, may be expelled only after proceedings conforming to traditional standards of fairness encompassed in due process of law"); T. ALEINIROFF \& D. MARTIN, supra note 15, at 408 ("The Japanese Immigrant Case [Yamataya] stands for the proposition that deportation procedures must conform to the dictates of the due process clause of the Constitution."). The Court did speak constitutionally. See 189 U.S. at 100 ("[T]his court has never held, nor must we now be understood as holding, that administrative officers, when executing the provisions of a statute involving the liberty of persons, may disregard the fundamental principles that inhere in "due process of law."). But the holding was also cast in subconstitutional terms. See id. at 101 ("The words here used do not require an interpretation that would invest executive or administrative officers with the absolute, arbitrary power implied in the contention of the appellant." The Court was not particularly careful to avoid deciding constitutional issues, in large part because it was willing to say that the constitutional norm was real. Two other examples of the Supreme Court's uncritical willingness to pronounce on constitutional issues may be found in the part of Wong Yang Sung that relies on a real constitutional norm, and in United States v. Witkovich, 353 U.S. 194, 201-02 (1957) (construing statute to limit Attorney General's authority to interrogate aliens in custody pending deportation because broader reading would raise constitutional doubts).

157. See T. ALEnNIKOFF \& D. MARTIN, supra note 15 , at 453-63. 
tional immigration law gradually became the engine that would drive constitutional change.

The Court's 1963 decision in Rosenberg v. Fleuti is one milestone in the transition from phantom to real of a norm recognizing a returning resident alien's stake. ${ }^{158}$ Fleuti, a permanent resident since 1952, took a short trip of "about a couple hours" to Mexico in $1956 .{ }^{159}$ In 1959, the Immigration and Naturalization Service ("INS") tried to deport him as an an alien "excludable by the law existing at the time of ... entry."160 The INS sought to declare Fleuti excludable on the ground that, by virtue of his homosexuality, Fleuti was "afflicted with psychopathic personality."161 The Ninth Circuit set aside the deportation, holding that, as applied to homosexuality, the term "psychopathic personality" was unconstitutionally vague. ${ }^{162}$ The Supreme Court held for Fleuti on the altogether different ground that he had not "entered" the United States in 1956. This conclusion was fatal to the government's case because "psychopathic personality" had become an exclusion ground between Fleuti's initial entry in 1952 and his possible "reentry" in 1956. If he last entered in 1952 , he had not been excludable at entry and thus was not deportable. Modifying the reentry doctrine significantly, the Court defined "entry" so as to avoid application where an alien returned to the United States from a temporary absence that was not "meaningfully interruptive" of permanent residence. ${ }^{163}$ The Fleuti Court reasoned that the 1952 Act, which had amended the statutorily imposed definition of "entry" expressly to exclude a return from an unexpected or involuntary absence, ${ }^{164}$ must also have intended to exempt "innocent, casual, and brief" trips like Fleuti's. ${ }^{165}$

158. 374 U.S. 449 (1963).

159. Id. at 450 .

160. INA § 241(a)(1), 8 U.S.C. § 1251(a)(1) (1988).

161. INA $\S 212(a)(4), 8$ U.S.C. $\S 1182$ (a)(4) (1988). The INS had argued earlier that Fleuti had been excludable in 1956 because he had been "convicted of a crime involving moral turpitude," INA $\S 212$ (a)(9), 8 U.S.C. § 1182(a)(9) (1988), but the crime turned out to be a petty offense insufficient for exclusion. See Fleuti v. Rosenberg, 302 F.2d 652, 656 n.10 (9th Cir. 1962), aff' d on other grounds, 374 U.S. 449 (1963); see also 374 U.S. at 450.

162. Fleuti v. Rosenberg, 302 F.2d 652, 655-58 (9th Cir. 1962) ("psychopathic personality" unconstitutionally vague absent case law that might have clarified statute), aff'd on other grounds, 374 U.S. 449 (1963).

163. 374 U.S. at 462 .

164. Act of June 27, 1952, Pub. L. No. $82-414, \S 101,66$ Stat. 163, 167. The amendment codified the holdings of two cases that had avoided especially harsh applications of the reentry doctrine. See Delgadillo v. Carmichael, 332 U.S. 388 (1947) (alien on sleeping car from Buffalo to Detroit, unaware that train would travel through Canada, did not "enter" upon arrival in Detroit); DiPasquale v. Karnuth, 158 F.2d 878 (2d Cir. 1947) (alien rescued and taken to Cuba for one week from ship that had been torpedoed and sunk did not "enter" upon his return to the United States).

165. 374 U.S. at 457-58 ("[T]he major congressional concern in codifying the definition of 'entry' was with 'the status of an alien who has previously entered the United States and resided therein ....' This concern was in the direction of ameliorating the harsh results visited upon resident aliens by the rule of United States ex rel. Volpe $v$. Smith . . . . Congress, in approving the judicial undermining of Volpe, and the relief brought about by the Di Pasquale and Delgadillo decisions, could not have meant to limit the meaning of the exceptions it created in $\S 101(a)(13)$ to the facts of those two cases." (citation omitted)). 
In large part, the majority's Fleuti opinion, like Chew, evinces sympathy for the view that immigration law inadequately recognized a permanent resident's stake in remaining in the United States. This observation explains several aspects of the opinion: the focus on the harshness of the leading reentry doctrine case, United States ex rel. Volpe v. Smith, ${ }^{166}$ and on the hardships that Fleuti would suffer if deported; ${ }^{167}$ citation to Chew for the observation that "a resident alien who leaves this country is to be regarded as retaining certain basic rights"; 168 and the call for "more civilized application of our immigration laws ...." 169 But as in Chew and Woodby, the constitutional norm that guided Fleuti's reading of "entry" was a phantom, which in turn explains why the Court decided the case by interpreting "entry" in the statute, rather than by striking down the statute as unconstitutional. No decision of the Court had openly recognized procedural due process rights for an alien seeking entry, not even for a returning permanent resident. Indeed, Mezei had suggested and perhaps even held to the contrary. Still, the phantom norm of procedural due process for returning permanent residents was close enough to the constitutional horizon that it is unsurprising that the Court adopted it as a guide to statutory interpretation. Using this norm, the Court construed "entry" to recognize stake, even if prevailing doctrine did not permit a direct constitutional holding.

The Court's recognition of Fleuti's stake through the definition of "entry," but not through other subconstitutional elements of the government's case against him, suggests that phantom norm decisions must rely on constitutional norms that are "real" enough to exercise gravitational pull, even if they have not yet appeared above the constitutional horizon. If the Court had found that Fleuti had "entered" in 1956, the case's center of gravity would have shifted to the statutory exclusion ground of "psychopathic personality" and the constitutional attack on that ground as void-for-vagueness. The term "psychopathic personality" and the term "entry" were similar in one respect-both required ignoring clear legislative intent before Fleuti could win a favorable subconstitutional outcome. Congress almost certainly intended the term "psychopathic personality" to apply to homosexuals. ${ }^{170}$ And, as Justice Clark noted in dis-

166. 374 U.S. at 453 (noting that Volpe had been deported "after 24 years of residence in this country"). United States ex rel. Volpe v. Smith, 289 U.S. 422 (1933), is discussed supra note 57.

167. 374 U.S. at 458 (Fleuti's interests are "high and momentous"); id. at 459 ("[d]eportation can be the equivalent of banishment or exile'") (citing Barber v. Gonzales, 347 U.S. 637, 642-43 (1954); Fong Haw Tan v. Phelan, 333 U.S. 6, 10 (1948); Bridges v. Wixon, 326 U.S. 135, 147 (1945); Ng Fung Ho v. White, 259 U.S. 276, 284 (1922)).

168. 374 U.S. at 460 .

169. Id. at 462.

170. The statute was enacted pursuant to a Senate Judiciary Committee report and recommendation that "homosexuals and other sex perverts" be excluded. S. REP. No. 1515, 81st Cong., 2d Sess. 345 (1950). The Senate Report accompanying the bill noted: "The Public Health Service has advised that the provision for the exclusion of aliens afflicted with psychopathic personality or a mental defect which appears in the instant bill is sufficiently broad to provide for the exclusion of homosexuals and sex perverts. This change of nomenclature is not to be construed in any way as modifying the intent to exclude all aliens who are sexual deviates." S. REP. No. 1137, 82 d Cong., 1st Sess. 9 (1950). See also H.R. REP. No. 1365, 82d Cong., 
sent, Congress probably also intended the term "entry" to cover Fleuti's return from Mexico, having allowed only limited exceptions to the statutory definition of "entry." Indeed, Congress had even rejected amendments that would have covered Fleuti. ${ }^{171}$ The Court's focus on "entry" reveals that a constitutional norm that would declare the term "psychopathic personality" void-for-vagueness was even more of a phantom, far off in the constitutional distance. In fact, seven years later the Court squarely rejected a vagueness challenge to the same statute. ${ }^{172} \mathrm{~A}$ judicial interpretation of the term "psychopathic personality" that did not include homosexuality would have required reliance on an even less palpable constitutional norm than did the interpretation of the word "entry." 173

Limits on what the Court could read into "entry" inevitably rendered Fleuti an incomplete solution. It did nothing for some returning permanent residents-those with a "meaningfully interruptive" absence-even if they could claim a "stake" of constitutional dimensions. ${ }^{174}$ Cases were bound to arise in which the statutory solution was inadequate, adding to the pressure for open recognition of the underlying constitutional reasoning. In a 1982 case, Landon v. Plasencia, ${ }^{175}$ the Court took the logical next step: it addressed the constitutional issue directly and made "real" the phantom constitutional norm that had previously been used only as a guide to statutory interpretation.

Maria Antonieta Plasencia, a citizen of El Salvador, had been a permanent resident of the United States since 1970. She lived in Los Angeles with her husband, who was a United States citizen, and their children. In 1975, the INS detained her upon her return from a brief trip she and her husband had taken

2d Sess. (1952), reprinted in 1952 U.S. CODE CONG. \& ADMIN. NEws 1652, 1701 (quoting and adopting Public Health Service report recommending that the term "psychopathic personality" be used to "specify such types of pathologic behavior as homosexuality or sexual perversion"). See generally Boutilier v. INS, 387 U.S. 118, 122 (1967) ("Congress used the phrase 'psychopathic personality' not in the clinical sense, but to effectuate its purpose to exclude from entry all homosexuals and other sex perverts."); Aleinikoff, supra note 86, at 47-54. But cf. Boutilier v. INS, 363 F.2d 488, 496-99 (2d Cir. 1966) (Moore, J., dissenting) (Congress intended to exclude only if homosexuality amounted to personality disorder in individual); Eskridge, GadamerlStatutory Interpretation, 90 CoLUM. L. REV. 609, 642-44 (1990) (discussing the difficulties of determining the legislative intent behind INA $\$ 212(a)(4))$.

171. See Fleuti, 374 U.S. at 463-68 (Clark, J., dissenting); see also T. ALERIKOFF \& D. MARTIN, supra note 15, at 335 ('Isn't Fleuti an embarassment to the United States Supreme Court? Isn't the dissent clearly correct that the majority rewrote the statute along the lines of proposals made to, but rejected by, Congress?"); Comment, Exclusion and Deportation of Resident Aliens: The Re-Entry Doctrine and the Need for Reform, 13 SAN DIEGO L. REV. 192, 197-200 (1975).

172. Boutilier v. INS, 387 U.S. 118, 123-24 (1967) (deportation ground not based on post-entry conduct, therefore "no necessity exists for guidance so that one may avoid the applicability of the law"; "Congress has plenary power to make rules for the admission of aliens."); see also Mahler v. Eby, 264 U.S. 32, 40-41 (1924); $c f$. Jordan v. De George, 341 U.S. 223, 229-32 (1951) (caselaw keeps deportation statute for crime of "moral turpitude" from being unconstitutionally vague).

173. At the time that the Court decided Fleuti, prevailing medical opinion had not yet changed in the way that later prompted the Ninth Circuit to interpret the statute not to permit exclusion of homosexuals without a medical certificate of excludability. See Hill v. INS, 714 F.2d 1470, 1481 (9th Cir. 1983), aff' $g$ Lesbian/Gay Freedom Day Comm. v. INS, 541 F. Supp. 569, 579-80 (N.D. Cal. 1982); see also infra text accompanying notes $287-94$.

174. The incomplete or underinclusive solution, which is a more general problem with phantom norm decisionmaking, is discussed more fully infra text accompanying notes 308-13.

175. 459 U.S. 21 (1982). 
to Mexico. The INS considered her excludable rather than deportable as an "entering" alien on the ground that the Fleuti exception did not apply. The Service then excluded her for allegedly having aided six Mexican and Salvadoran nationals, who traveled with her in their attempt illegally to enter the United States. ${ }^{176}$ After the Board of Immigration Appeals (BIA) dismissed Plasencia's appeal, she successfully filed for habeas corpus in the district court, which found that the INS had mistakenly placed her in the exclusion category for the purpose of deciding if her return was an "entry." A Ninth Circuit panel affirmed, relying heavily on Chew. The panel declared broadly: "[A] permanent resident alien does not lose the procedural protection to which he is otherwise entitled simply by making a brief journey abroad."177 But the constitutional norm that would afford procedural due process to reentering permanent residents in exclusion hearings was just a phantom, and understandably the panel limited itself to interpreting the statute to afford Plasencia a deportation hearing to decide whether her return was an "entry."

The Supreme Court could have affirmed on the statutory ground, a course that would have been consistent with its approach in Chew and Fleuti. Instead, it construed the statute to label Plasencia as excludable rather than deportable. Reaching the constitutional issue, the Court held that even a returning permanent resident subject to exclusion "can invoke the Due Process Clause ...."178 The Court distinguished Mezei as involving a much longer absence ${ }^{179}$ and held that an alien's constitutional status does not depend strictly on the statutory exclusion or deportation categories. The Court openly recognized its holding's pedigree by relying heavily on the same constitutional considerations that had guided statutory interpretation in Chew and Fleuti. "[O]nce an alien gains admission to our country and begins to develop the ties that go with permanent residence, his constitutional status changes accordingly." "I80 Justice O'Connor wrote that "[a]lthough the holding [in Chew] was one of regulatory interpretation, the rationale was one of constitutional law,"

176. INA § 212(a)(31), 8 U.S.C. § 1182(a)(31) (1988), excludes "[a]ny alien who at any time shall have, knowingly and for gain, encouraged, induced, assisted, abetted, or aided any other alien to enter or to try to enter the United States in violation of law."

177. Plasencia v. Sureck, 637 F.2d 1286, 1288 (9th Cir. 1980), rev'd sub nom. Landon v. Plasencia, 459 U.S. 21 (1982).

178. 459 U.S. at 32. The Court declined to say if the process afforded to Plasencia was sufficient and remanded on that issue.

179. Id. at 34 .

180. Id. at 32 (citing Johnson v. Eisentrager, 339 U.S. 763, 770 (1950)). See also D. MARTI, supra note 9, at 24 ("After Plasencia, due process protection no longer turns entirely on the distinction between exclusion cases and deportation cases-that is, on whether the alien is at the border or in the interior of the country. In some settings, at least, the courts may undertake a more sensitive inquiry into the alien's community ties in assessing procedural requirements under the Constitution."); $c f$. Rafeedie v. INS, 880 F.2d 506, 519-25 (D.C. Cir. 1989) (preliminary injunction against summary exclusion of returning permanent resident), discussed in greater detail infra text accompanying notes 322-28. 
and she cited Fleuti as having acknowledged this aspect of Chew. ${ }^{181}$ In Chew and Fleuti the constitutional norms were phantoms, and Plasencia transformed them into "real" constitutional immigration law.

\section{CONTEMPORARY PLENARY POWER: CONSTITUTIONAL V. STATUTORY LAW}

\section{A. Phantom Norm Review of Executive Action}

Plasencia is vital to this story because it shows that phantom norms can represent a transitional phase. But Plasencia addressed just one constitutional aspect of classical immigration law-procedural due process for returning permanent residents-leaving many others untouched. It said nothing about substantive constitutional claims by permanent residents, such as the claim that the Constitution prevents the government from deporting them for speech protected by the First Amendment. Nor did Plasencia say anything about claims asserted by those who were not permanent residents. In other recent cases, courts have recognized some of these claims through subconstitutional decisions guided by phantom constitutional norms, as in Chew and Fleuti. It remains to be seen whether these phantom norms will become part of the directly applied constitutional immigration law.

These recent phantom norm decisions have endorsed some degree of judicial review of immigration decisions committed by Congress to an agency of the executive branch. Of course, some of the earlier phantom norm decisions, certainly including both $C h e w$ and Woodby, also can be characterized as judicial review of agency decisions. But more recent cases vary from the early phantom norm decisions in one important sense. Their reasoning is distinctive-it relies heavily on first characterizing the decision as one of agency rather than legislative action, and then scrutinizing that agency action for subconstitutional defects.

The genesis of this decisionmaking pattern is complex; it reflects the emergence and combination of four views about the proper scope of judicial review. First, courts are more competent to review immigration decisions by agencies than by Congress. The first element is best explained through the Court's 1972 decision in Kleindienst $v$. Mandel, which upheld the denial of a

181. 459 U.S. at 33 ("Any doubts that Chew recognized constitutional rights in the resident alien returning from a brief trip abroad were dispelled by Rosenberg $v$. Fleuti, where we described Chew as holding "that the returning resident alien is entitled as a matter of due process to a hearing on the charges underlying any attempt to exclude him." "). See also Rafeedie v. INS, 880 F.2d 506, 520-21 (D.C. Cir. 1989) ("Chew was a constitutional decision"), aff" $g$ in part and rev' $g$ in part 688 F. Supp. 729, 743 (D.D.C. 1988) ("While the Supreme Court in Chew cast its conclusion in statutory terms, the decision itself and subsequent cases have made clear that the rationale was a constitutional one; even though the Court did not hold the regulation facially unconstitutional, it found that the statute could not constitutionally be applied to Chew.") (footnote and citations omitted). 
nonimmigrant visa to Ernest Mandel, a Belgian journalist and self-described "revolutionary Marxist." 182 In 1968, Mandel received invitations from various universities throughout the United States. For two earlier visits, the government, without his knowledge, had exercised its statutory discretion to waive the exclusion ground for Communists, but this time it declined to do so. ${ }^{183}$ Mandel and several of the United States citizen professors who had invited him sued, relying primarily on the argument that the First Amendment guaranteed them the right to meet and speak with Mandel. ${ }^{184}$

Mandel is important for our purposes because in that case the Court suggested a distinction between decisions made directly by Congress in an immigration statute and enforcement of those statutes by the executive branch. According to the Court, the plaintiffs raised a First Amendment challenge not to the plenary power doctrine itself, but just to the Attorney General's discretionary decision not to waive exclusion. ${ }^{185}$ The government argued that the Attorney General is vested with "sole and unfettered discretion" to deny waiver by giving "any reason or no reason" at all, ${ }^{186}$ but the Court found that it did not need to decide this question. Instead, it found that the Attorney General had given a "facially legitimate and bona fide reason" for his decision, and that this foreclosed further judicial review. ${ }^{187}$ But by distinguishing the plenary power cases and conditioning its approval of discretionary decisions by requiring the government to offer a "facially legitimate and bona fide reason," the Court suggested some outer limits to executive discretion that might not apply to direct congressional decisions.

Mandel's suggested distinction between executive actions and legislative acts has found its way into lower court decisions that have scrutinized executive branch immigration decisions more closely than the plenary power doctrine would seem to allow. ${ }^{188}$ The distinction reflects the view that courts intrude

182. 408 U.S. $753,769-70$ (1972).

183. INA § 212(d)(3)(A), 8 U.S.C. § 1182(d)(3) (1988), allows discretionary waiver of the ideological exclusion grounds applied to Mandel, which were INA § 212(a)(28)(D) \& (G)(v), 8 U.S.C. § 1182(a)(28)(D) $\&(G)(v)(1988)$.

184. The original complaint also alleged violations of equal protection and procedural due process, see 408 U.S. at 760 , but these issues were not before the Court.

185. Id. at 767. Justice Marshall, joined by Justice Brennan, dissented on the grounds that the constitutionality of $\S 212$ (a)(28) necessarily came into question, since no waiver would have been necessary without that subsection. Id. at 777-84.

186. Id. at 769.

187. Id. at 770 ("In the case of an alien excludable under $\$ 212(\mathrm{a})(28)$, Congress has delegated conditional exercise of this power ['to make policies and rules for exclusion of aliens'] to the Executive. We hold that when the Executive exercises this power negatively on the basis of a facially legitimate and bona fide reason, the courts will neither look behind the exercise of that discretion, nor test it by balancing its justification against the First Amendment interests of those who seek personal communication with the applicant."). Cf. id. at 774 (Douglas, J., dissenting) (Attorney General exceeded his statutory powers because his discretion was limited to "matters commonly within the competence of the Department of Justice-national security, importation of drugs, and the like").

188. See, e.g., Abourezk v. Reagan, 785 F.2d 1043, 1061 (D.C. Cir. 1986) ("The Executive has broad discretion over the admission and exclusion of aliens, but that discretion is not boundless. It extends only as far as the statutory authority conferred by Congress and may not transgress constitutional limitations. 
on the legislative sphere more when they review decisions made by Congress directly than when they review immigration decisions made by the executive branch pursuant to a delegation of power by Congress. ${ }^{189}$ This maxim is especially powerful when the executive operates under a broad grant of authority from Congress rather than under narrow or specific congressional direction. ${ }^{190}$ With the addition of the three other elements, judicial scrutiny-at least in some cases-was to become less restrained than Mandel's apparently deferential "facially legitimate and bona fide reason" formula would suggest.

The second view that contributed to this decisionmaking pattern was unremarkable and well established-that courts can review immigration decisions under a subconstitutional "arbitrary and capricious" or "abuse of discretion" test, to make sure the executive branch has stayed within congressionally

It is the duty of the courts, in cases properly before them, to say where those statutory and constitutional boundaries lie."), aff' $d$ by an equally divided Court, 484 U.S. 1 (1987); Louis v. Nelson, 544 F. Supp. 973, 998 (S.D. Fla. 1982), aff'd sub nom. Jean v. Nelson, 711 F.2d 1455 (11th Cir. 1983), rev'd, 727 F.2d 957 (11th Cir. 1984) (en banc), aff'd as modified, 472 U.S. 846 (1985) (emphasizing importance of distinction between review of congressional and agency action); Haitian Refugee Center v. Civiletti, 503 F. Supp. 442, 452 (S.D. Fla. 1980) ("power of INS is more circumscribed [than Congress']. . . . Where it has been given discretion by statute or treaty, INS may not exercise that discretion arbitrarily or capriciously.'), aff $d$ as modified sub nom. Haitian Refugee Center v. Smith, 676 F.2d 1023 (5th Cir. Unit B 1982). But cf. Schuck, supra note 6, at 15 ("Court has not hesitated to extend this 'special judicial deference to congressional policy choices in the immigration context' to administrative officials as well as to the Congress.") (footnote omitted).

Even after Mandel, courts still routinely refuse to review visa denials by consular officers overseas. See, e.g., Li Hing of Hong Kong, Inc. v. Levin, 800 F.2d 970, 971 (9th Cir. 1986); Burrafato v. Department of State, 523 F.2d 554, 556 (2d Cir. 1975), cert. denied, 424 U.S. 910 (1976); Pena v. Kissinger, 409 F. Supp. 1182, 1185-87 (S.D.N.Y. 1976); cf. Wong v. Department of State, 789 F.2d 1380, 1384-85 (9th Cir. 1986) (judicial review of visa revocation, with alien in United States); Shimizu v. Department of State, CV 89-2741-WMB (C.D. Cal. May 31, 1990), digested in 67 INTERPRETER RELEASES 699, 702 (1990) (judicial review of visa revocation, with alien outside United States). For background and analysis regarding visa denials and their reviewability, see Recommendation of the Administrative Conference of the United States, 1 C.F.R. § 305.89-9 (1990); Martin, Mandel, Cheng Fan Kwok, and Other Unappealing Cases: The Next Frontier of Immigration Reform, 27 VA. J. INT'L L. 803, 809-14 (1987).

189. Executive decisions may be less appropriate for judicial review than direct legislative decisions because they are more "political," but the courts have gradually abandoned the political question doctrine as a basis for declining judicial review in immigration cases. See, e.g., Orantes-Hernandez v. Meese, 685 F. Supp. 1488, 1503 (C.D. Cal. 1988); Harvard Law School Forum v. Shultz, 633 F. Supp. 525, 528 (D. Mass. 1986); $c f$. INS v. Chadha, 462 U.S. 919 (1983), which held unconstitutional the power of either house of Congress, by resolution, to overrule discretionary suspension of deportation by the Attorney General for reasons of "extreme hardship" under INA $\S 244(\mathrm{a})(1)$, (c)(2), 8 U.S.C. $\S 1254(\mathrm{a})(1)$, (c)(2) (1988). "The plenary authority of Congress over aliens under [the naturalization clause] is not open to question, but what is challenged here is whether Congress has chosen a constitutionally permissible means of implementing that power." 462 U.S. at $940-41$. The decision seems confined to constitutional challenges based on separation of powers, instead of limiting plenary power generally, and thus seems akin to the cases that recognize more judicial competence to hear procedural due process claims than attacks on substantive immigration classifications. Cf. Fiallo v. Bell, 430 U.S. 787, 794 (1977) ("no occasion to consider in this case whether there may be actions of the Congress with respect to aliens that are so essentially political in character as to be nonjusticiable"). See generally Legomsky, supra note 5, at 255, 261-69.

190. See, e.g., Narenji v. Civiletti, 481 F. Supp. 1132, 1140 (D.D.C. 1979) (less judicial review if case involves "a specific statutory enactment of Congress"), rev"d on other grounds, 617 F.2d 745 (D.C. Cir. 1979), cert. denied, 446 U.S. 957 (1980). 
prescribed bounds. ${ }^{191}$ Third, judicial review for an "arbitrary and capricious" decision or an "abuse of discretion" includes a look at any constitutional doubts about the agency decision. Put differently, an executive branch decision is an "abuse of discretion" or "arbitrary and capricious" if it relies on unconstitutional premises. ${ }^{192}$

The fourth and capstone element was that courts may broaden the grounds for an "arbitrary and capricious" or "abuse of discretion" finding to include conflict between agency action and a phantom constitutional norm. In other words, even if constitutional doubts about an agency decision are insufficient to justify finding it unconstitutional, courts still express those doubts at a subconstitutional level through an "arbitrary and capricious" or "abuse of discretion" finding. The reasoning might be that the agency abused its discretion by violating a phantom constitutional norm, or that the agency exceeded its delegated powers under a statute that would be interpreted narrowly using a phantom constitutional norm. In either case, the court effectively undermines what would seem to be the governing principles of constitutional immigration law.

\section{B. Jean v. Nelson and Other Phantom Norm Decisions}

Thanks to these four elements, in the past decade, phantom norm-based subconstitutional review of agency action-a variation on the phantom norm decisions of the 1950's and 1960's- has become a widespread method of deciding difficult immigration cases in many of the areas left open in Plasencia. These more recent immigration cases, like the early phantom norm decisions, represent a partial integration into immigration law of the values embodied in Yick Wo's treatment of aliens outside of immigration law. ${ }^{193}$

Graham v. Richardson, ${ }^{194}$ a 1971 Supreme Court decision, is a seminal case in Yick Wo's modern legacy. Graham struck down a state-imposed residency requirement limiting lawfully admitted aliens' access to welfare benefits. The law pertaining to citizenship requirements is just one aspect of the question whether the Constitution protects aliens. Although Yick Wo involved race, not alienage, recent alienage cases suggest that Yick Wo remains alive and well. Beginning its equal protection analysis with that case, the near-unanimous

191. See, e.g., Foti v. INS, 375 U.S. 217, 228-30 (1963) (abuse of discretion is standard for judicial review of denials of discretionary relief from deportation); Carlson v. Landon, 342 U.S. 524, 544 (1952) (applying "clear abuse of discretion" standard in upholding the Attorney General's refusal to release aliens on "bail" pending deportation proceedings, while noting "the executive judgment is limited by adequate standards"); cf. United States ex rel. Accardi v. Shaughnessy, 347 U.S. 260, 268 (1954) (Board of Immigration Appeals must exercise discretion conferred upon it by regulation).

192. See, e.g., Wong Wing Hang v. INS, 360 F.2d 715, 719 (2d Cir. 1966) (agency decision is "abuse of discretion if ... made without a rational explanation, inexplicably depart[s] from established policies, or rest[s] on an impermissible basis such as an invidious discrimination against a particular race or group").

193. These earlier cases are discussed supra text accompanying notes 94-108.

194. 403 U.S. 365 (1971). 
Graham Court declared: "[C]lassifications based on alienage, like those based on nationality or race, are inherently suspect and subject to close judicial scrutiny. Aliens as a class are a prime example of a 'discrete and insular' minority ... for whom such heightened judicial solicitude is appropriate."195

Plyler v. Doe, ${ }^{196}$ a 1982 Supreme Court decision, has similarly broad implications. Relying heavily on Yick Wo and Wong Wing, the Court said that even undocumented aliens are entitled to constitutional protections and struck down a Texas statute that effectively barred children of undocumented aliens from attending public schools. Although the Court declined to say that undocumented aliens are a "suspect class," 197 it found the state statute was not rational because it did not further "some substantial goal of the State." 198 More fundamentally, Plyler recognized a radically broader view of the constitutionally protected community than that implicit in the plenary power doctrine. Plyler recognized the membership of these undocumented children in American society as an accomplished fact, and further recognized that they could not be excluded by fiat from constitutional rights and privileges. ${ }^{199}$

The Court's reasoning in Graham and Plyler seemed broad enough to limit not only state laws, which were at issue in those cases and in most recent decisions invalidating citizenship requirements, ${ }^{200}$ but the federal laws as well. ${ }^{201}$ But in fact, the Court has recognized that the federal government's

195. Id. at 371-72 (8-0 decision with Harlan, J. concurring) (citing United States v. Carolene Prods. Co., 304 U.S. 144, 152-53 n.4 (1938)).

196. 457 U.S. 202 (1982).

197. Id. at 219 n.19.

198. Id. at 224.

199. See Schuck, supra note 6, at 54 (Plyler "may mark a fundamental break with classical immigration law's concept of national community and of the scope of congressional power to decide who is entitled to the benefits of membership."). Schuck supports this broad reading of Plyler in part by comparing it with De Canas v. Bica, 424 U.S. 351 (1976), which suggested that states may enact legislation that discourages immigration in ways that are generally consistent with federal policy. Id. at 57 . On this broadening of the national community in general, see Aleinikoff, Membership, supra note 102, at 20-22; Bosniak, supra note 102, at 967-87; Rosberg, The Protection of Aliens From Discriminatory Treatment by the National Government, 1977 SUP. CT. REV. 275; Schuck, supra note 6, at 34-58; cf. Lopez, Undocumented Mexican Migration: In Search of a Just Immigration Law and Policy, 28 UCLA L. REV. 615, 700 (1981) ("If that set of attributes [heretofore assumed to be shared only by citizens] is now shared by people without citizenship, the interests of that group must be acknowledged and considered; any moral theory of community status that fails to take account of these interests will lose its purpose for being.").

200. See, e.g., Bernal v. Fainter, 467 U.S. 216 (1984) (notaries public); Nyquist v. Mauclet, 432 U.S. 1 (1977) (recipients of financial assistance for higher education); Examining Bd. of Eng'rs v. Otero, 426 U.S. 572 (1976) (civil engineers); In re Griffiths, 413 U.S. 717, 718 n.3 (1973) (attorneys); Sugarman v. Dougall, 413 U.S. 634, 646 (1973) (civil service employees); Truax v. Raich, 239 U.S. 33 (1915) (employees in general).

201. In Graham the Court expressly refrained from deciding if Congress could enact a statute imposing on aliens a uniform nationwide residency requirement as a condition of federally funded welfare benefits. 403 U.S. at 382 n.14. But it discussed supremacy separately as an "additional," and thus, perhaps unnecessary reason for its holding. Id. at 376-77; see also Nyquist v. Mauclet, 432 U.S. 1, 12 (1977); In re Griffiths, 413 U.S. 717, 718 n.3 (1973); Sugarman v. Dougall, 413 U.S. 634, 646 (1973); cf. Toll v. Moreno, 458 U.S. 1, 10 (1982) (state university's policy of denying in-state status to holders of certain nonimmigrant visas is invalid under the supremacy clause; Court did not reach due process and equal protection issues); Graham, 403 U.S. at 383 (Harlan, J., concurring) (supremacy clause sufficient to invalidate state law); Hines v. Davidowitz, 312 U.S. 52, 68 (1941) (under supremacy clause, federal alien registration statute precludes 
constitutional power over immigration and naturalization gives it greater freedom from judicial scrutiny when it classifies by alienage. Hampton v. Mow Sun Wong, ${ }^{202}$ decided in 1976, involved a challenge to a Civil Service Commission regulation that made aliens ineligible for most federal employment, much like the state regulations that the Court had invalidated three years earlier in Sugarman v. Dougall. ${ }^{203}$ The Court struck down the federal regulation as a deprivation of liberty without due process, because it was unwilling to find that the Commission had acted in furtherance of national interests connected with the immigration and naturalization power. ${ }^{204}$ But the Court suggested that either Congress or the President would have the power to bar aliens from federal jobs; indeed, lower courts have consistently upheld the Executive Order issued by President Ford shortly after Mow Sun Wong. ${ }^{205}$ On the same day that the Court decided Mow Sun Wong, it also decided Mathews v. Diaz, ${ }^{206}$ which challenged a statute, similar to the state welfare rules struck down in Graham, that barred aliens from access to federal Medicare unless they were permanent residents who had lived in the United States for five years. The Court in Diaz upheld the statute, reasoning that "[i]n the exercise of its broad power over naturalization and immigration, Congress regularly makes rules that would be unacceptable if applied to citizens." ${ }^{207}$

The ultimate results in the Mow Sun Wong and Diaz litigation sustained the power of Congress and the executive branch, and even in the case law concerning state classifications, Graham and Plyler remain high-water marks. But the key lesson is that the reasoning of all of these alienage cases carried on the Yick Wo tradition. ${ }^{208}$ The Court allowed constitutional scrutiny, squarely and seriously considering the rights of aliens, in contrast to its cavalier treatment of many constitutional claims in immigration cases. Mow Sun Wong said that distinctions between aliens and citizens merited constitutional scrutiny. ${ }^{209}$ In Diaz, the Court began by citing Wong Yang Sung, Wong Wing, and Russian Volunteer Fleet for the proposition that the Constitution protects aliens from deprivations of life, liberty, or property without due process, even if their

enforcement of state alien registration statute). Rosberg, supra note 199, at 316-36, argues that the constitutional limits on classification by alienage should apply to federal as well as state government.

202. 426 U.S. 88 (1976).

203. 413 U.S. 634 (1973); cf. In re Griffiths, 413 U.S. 717 (1973) (state exclusion of aliens from practice of law is unconstitutional).

204. 426 U.S. at $105,114-16$.

205. See, e.g., Mow Sun Wong v. Campbell, 626 F.2d 739, $744-45$ (9th Cir. 1980), cert. denied, 450 U.S. 959 (1981); Jalil v. Campbell, 590 F.2d 1120, 1123 n.3 (D.C. Cir. 1978); Vergara v. Hampton, 581 F.2d 1281, 1284-85 (7th Cir. 1978), cert. denied, 441 U.S. 905 (1979).

206. 426 U.S. 67 (1976).

207. $I d$. at $79-80$.

208. See Aleinikoff, Federal Regulation, supra note 102, at 865 ("The legacy of Yick Wo has also survived and flourished in the 20th century. Outside the immigration process, aliens receive most of the constitutional protections afforded citizens."). Yick Wo v. Hopkins, 118 U.S. 356 (1886), and its immediate progeny are discussed supra text accompanying notes 94-108.

209. 426 U.S. at 101-03. 
presence in the country is unlawful, involuntary, or transitory. ${ }^{210}$ Diaz also endorsed the view that the character of an alien's stake has constitutional significance. ${ }^{211}$

Even decisions that have upheld certain types of state alienage classifications began their analysis with Yick Wo. ${ }^{212}$ And in the spirit of Wong Wing, the Court has also made it clear that the Fourth Amendment protects aliens in the United States, even if the actual holding favored the government. ${ }^{213}$ Lower courts have held that aliens are entitled to Miranda warnings in any custodial interrogation that seeks information to be used against them in criminal proceedings, ${ }^{214}$ and that excludable aliens are entitled under the due process clauses of the Fifth and Fourteenth Amendments to be free of gross physical abuse at the hands of state or federal officials. ${ }^{215}$ And when the underlying issue is not alienage alone, but race as in Yick Wo itself, the Constitution protects persons whether they are citizens or aliens. ${ }^{216}$ It is also significant that in several cases recognizing aliens' constitutional rights, the dissent's approach, rejected by implication, was to reason directly from the plenary power cases in immigration law. ${ }^{217}$

210. Diaz, 426 U.S. at 77. Wong Yang Sung v. McGrath, 339 U.S. 33 (1950), is discussed supra text accompanying notes 121-30; Wong Wing v. United States, 163 U.S. 228 (1896), is discussed supra text accompanying notes 97-99; and Russian Volunteer Fleet, 282 U.S. 481 (1931), is discussed supra text accompanying note 100 .

211. 426 U.S. at 80 ("The decision to share that bounty ["that a conscientious sovereign makes available to its own citizens and some of its guests"] with our guests may take into account the character of the relationship between the alien and this country ....") (emphasis in original).

212. See, e.g., Cabell v. Chavez-Salido, 454 U.S. 432, 436 (1982) (probation officers); Ambach v. Norwick, 441 U.S. 68, 72 (1979) (public school teachers). These cases permit denying aliens political rights and employment that are believed to be closely tied to the political functions of government; see also Foley v. Connelie, 435 U.S. 291 (1978) (state troopers).

213. See United States v. Martinez-Fuerte, 428 U.S. 543, 566-67 (1976) (Fourth Amendment permits Border Patrol's routine stop of vehicle at permanent checkpoint near border without individualized suspicion); United States v. Ortiz, 422 U.S. 891, 896-97 (1975) (Fourth Amendment bars warrantless search of vehicle without probable cause at permanent checkpoint near border); United States v. Brignoni-Ponce, 422 U.S. 873, 878-87 (1975) (Fourth Amendment bars roving Border Patrol stop of vehicle near border based only on appearance of occupants); Almeida-Sanchez v. United States, 413 U.S. 266, 273 (1973) (Fourth Amendment bars warrantless search of vehicle without probable cause by roving Border Patrol); cf. United States v. Verdugo-Urquidez, 110 S. Ct. 1056 (1990) (Fourth Amendment does not apply to search by United States authorities of Mexican residence of Mexican citizen and resident who had no voluntary attachment to United States).

214. United States v. Henry, 604 F.2d 908, 913-15 (5th Cir. 1979).

215. Lynch v. Cannatella, 810 F.2d 1363, 1372-74 (5th Cir. 1987); $c f$. Medina v. O'Neill, 589 F. Supp. $1028,1040-42$ (S.D. Tex. 1984) (harsh conditions of detention of excludable stowaway aliens violated due process).

216. See Takahashi v. Fish \& Game Comm'n, 334 U.S. 410 (1948); Yick Wo v. Hopkins, 118 U.S. 356 (1886).

217. See Mow Sun Wong, 426 U.S. at 117-18, 121-22, 127 (Rehnquist, J., dissenting) (citing Kleindienst v. Mandel, 408 U.S. 753 (1972); Galvan v. Press, 347 U.S. 522 (1954); Harisiades v. Shaughressy, 342 U.S. 580 (1952), and Fong Yue Ting v. United States, 149 U.S. 698 (1893)); Almeida-Sanchez, 413 U.S. at 291 (White, J., dissenting) (citing Kleindienst v. Mandel, 408 U.S. 753 (1972); Chae Chan Ping v. United States, 130 U.S. 581 (1889); Fong Yue Ting v. United States, 149 U.S. 698 (1893), and other plenary power cases). 
Indeed, judges who have rendered phantom norm decisions have relied heavily on Yick Wo values. The most prominent example of recent phantom norm decisionmaking based on these values is Jean v. Nelson, ${ }^{218}$ which concerned claims of racial and national origin discrimination in connection with detention of Haitian asylum applicants. Similar reasoning is evident in the lower courts. The discussion that follows attempts to identify and analyze some of the most important of those decisions. It is not intended to be a complete catalog of recent phantom norm decisions. Rather, it seeks to demonstrate the broad influence of this judicial practice by focusing on four important areas of immigration law in which phantom norms seem to explain a number of the most significant recent cases. They are: race and national origin discrimination claims, indefinite detention of Mariel Cubans, asylum procedures for excludable first-time entrants, and First Amendment challenges to exclusion grounds.

Much as Chew had done, some of these decisions have stopped short of declaring executive action unconstitutional and simply invalidated executive action solely on an articulated "abuse of discretion" or similar rationale. These decisions often openly express constitutional skepticism that lacks support in the immigration law precedents. This reasoning allows us to identify them as phantom norm decisions. Wè can identify other decisions as phantom norm decisions because those courts have also made alternative findings of unconstitutionality, again based on phantom norms with little support in immigration law. Appellate courts sometimes reverse these constitutional holdings, and sometimes not. In some settings, evidence suggests that phantom norms are evolving, as illustrated by Plasencia, toward directly applicable constitutional immigration law.

\section{Race and National Origin Discrimination: Haitians and Others}

Jean is the most prominent, but not the first, of several recent cases that raised the issue whether government policy toward aliens from certain countries unlawfully discriminates on the basis of race and national origin. A 1979 decision, Narenji v. Civiletti, ${ }^{219}$ tested special reporting requirements for Iranian students after the takeover of the American Embassy in Teheran. The district court reached alternative findings. Subconstitutionally, it decided that the regulations establishing the requirements lacked statutory authority because the enabling statute was "drawn neutrally." The court found "no statutory basis for the discriminatory classification established by the regulation such that defendants could cloak their rule's discriminatory effect in the mantle of congressio-

218. 472 U.S. 846 (1985). $(1980)$.

219. 481 F. Supp. 1132 (D.D.C.), rev'd, 617 F.2d 745 (D.C. Cir. 1979), cert. denied, 446 U.S. 957 
nal approval under its power over immigration and naturalization and thereby for practical purposes, exempt the regulation from judicial scrutiny."220

There is ample evidence that the subconstitutional holding in Narenji was based on a phantom constitutional norm barring national origin classifications. The court's discussion of the statute follows a citation to Yick Wo for the notion that mainstream equal protection analysis should apply to the students' claim of unconstitutional discrimination. ${ }^{221}$ The court also relied on statutes from outside immigration law to establish that "Congress has indicated its disdain for discrimination based on national origin."222 The court's thinking is also clear from the rest of its opinion, which relied on Mow Sun Wong ${ }^{223}$ to hold in the alternative that the regulation was an unconstitutional violation of equal protection. ${ }^{224}$ The District of Columbia Circuit subsequently reversed on both subconstitutional and constitutional grounds. In so rejecting the district court's constitutional reasoning, the appeals court confirmed that the lower court's reasoning was based on a background constitutional norm that was phantom, not real.

Other phantom norm decisions involving race and national origin discrimination claims arose in the context of migration of Haitians to the United States, most of whom sought political asylum. Until 1982, aliens at the border who appeared inadmissible were usually released on parole pending exclusion hearings. That year, the government, largely responding to the Haitian influx, announced that almost all aliens arriving without entry documents, as most Haitians did, would be detained instead. 225

Haitian Refugee Center v. Civiletti, ${ }^{226}$ a 1980 case from the Southern District of Florida involving claims of national origin discrimination and denial of due process, reached alternative subconstitutional and constitutional findings as did the court in Narenji v. Civiletti. First, the court found that the INS lacked statutory authority to discriminate on the basis of national origin or race where Congress had not employed those criteria. ${ }^{227}$ That this subconstitutional hold-

220. 481 F. Supp. at 1141.

221. Id. at 1138 ("Plaintiffs are quite correct in their assertions that the classification in this instance is one founded upon national origin and that the constitutional guarantee of equal protection can be evoked in most circumstances to protect against the government's invocation of such a standard, even in its dealings with aliens.") (citing Yick Wo). The court continued: "[]t has been long acknowledged that distinctions based on ancestry or national origin are "odious to a free people whose insitutions are founded upon the doctrine of equality." 'Id. at 1139 (citing Hirabayashi v. United States, 320 U.S. 81, 100 (1943)).

222. 481 F. Supp. at 1141 (citing 42 U.S.C. $\$ 2000$ a (1976) (public accommodations); 42 U.S.C. $\S 2000 \mathrm{~b}$ (public facilities); id. § $2000 \mathrm{e}-2$ (employment)).

223. 481 F. Supp. at 1144.

224. Id. at 1145 .

225. See 47 Fed. Reg. 30,044 (1982) (as amended at 47 Fed. Reg. 46,493 (1982)) (amending 8 C.F.R. $\S 235.3(\mathrm{~b}))$.

226. 503 F. Supp. 442 (S.D. Fla. 1980), aff'd as modified sub nom. Haitian Refugee Center v. Smith, 676 F.2d 1023 (5th Cir. Unit B 1982).

227. 503 F. Supp. at 453 ("INS has no authority to discriminate on the basis of national origin or race-except perhaps by promulgating regulations in a time of national emergency"); $c f$. id. at 452 ("Congress, if it so chooses, may discriminate against and among aliens on grounds which would violate the 
ing rested on a constitutional foundation is evident from the opinion as a whole, especially in its overwhelming emphasis on the constitutional issues and its tendency to treat constitutional and subconstitutional analysis as virtually indistinguishable. ${ }^{228}$ The nature of that constitutional foundation is clear from the court's alternative finding of unconstitutional national origin discrimination. To make this finding, the court borrowed norms from mainstream constitutional law-relying most prominently on Yick $W^{229}$ and Graham $^{230}$-that remained phantoms in the immigration law context. ${ }^{231}$ The Fifth Circuit did not reverse on the constitutional issue, but it expressed skepticism by noting: "[W]e do not address the equal protection contentions any more than to observe that we do not approve the sweeping conclusions of the district court." ${ }^{232}$

The plaintiffs in Vigile v. Sava, ${ }^{233}$ a 1982 district court case, similarly attacked INS detention policy toward Haitian asylum applicants as an abuse of discretion and as race and national origin discrimination proscribed by the Constitution and international law. The court granted the plaintiffs' relief, but restricted its holding to a subconstitutional level. Recognizing that the plenary power doctrine barred direct attacks on racial or national origin, the court avoided a directly constitutional holding. Instead, it subsumed all substantive issues in the case under abuse of discretion analysis, declaring that "invidious racial or national origin based discrimination constitutes abuse of discretion when insinuated into a neutral grant of decision-making authority."234

A Second Circuit panel reversed on the ground that the district court's review for abuse of discretion had been overbroad. ${ }^{235}$ But importantly, the panel agreed with the district court's use of subconstitutional abuse of discretion analysis to borrow constitutional norms from other areas of public law, even

Constitution if applied to American citizens.").

228. Id. at 456 (coming very close to equating violations of regulations and operating procedures with denials of procedural due process as a constitutional matter). The Fifth Circuit noted this on appeal. Haitian Refugee Center, 676 F.2d at 1036 n.29.

229. 503 F. Supp. at 471 n. 50 .

230. Id. at 454 .

231. Id. at 532 (government policy "is of fensive to every notion of constitutional due process and equal protection").

232. Haitian Refugee Center, 676 F.2d at 1041.

233. 535 F. Supp. 1002 (S.D.N.Y. 1982), rev'd on other grounds sub nom. Bertrand v. Sava, 684 F.2d 204 (2d Cir. 1982).

234. 535 F. Supp. at 1016; id. at 1007 ("review for abuse of parole discretion is the norm. While displaying total restraint on issues of exclusion, federal courts have examined the treatment of aliens awaiting that final order."; blanket denial of parole to almost all Haitians was abuse of discretion); id. at 1016 ("Even though Congress may employ race or national origin as criteria in determining which aliens to exclude from the country, a district director may not apply neutral regulations to discriminate on such grounds."). The court reconciled its subconstitutional holding with the plenary power doctrine as follows: Judicial review of the parole process, therefore, does not impinge upon the political judgment to exclude or accept nor interfere with the executive and legislative power to control our borders. It only insures that parole status, which Congress has determined does not necessarily interfere with such control, is conferred by district directors within the bounds anticipated by the delegation of discretion.

Id. at 1006.

235. Bertrand v. Sava, 684 F.2d 204, 213-18 (2d Cir. 1982). 
when those norms had never been established in constitutional immigration law. The panel stated, for example, that "immigration policies based on criteria that are not acceptable elsewhere in our public life" would be inconsistent with the "facially legitimate and bona fide reason" required by Kleindienst $v$. Mandel. ${ }^{236}$

In Jean v. Nelson, a class of Haitian asylum applicants also claimed that the INS detention policy unconstitutionally discriminated on the basis of race and national origin. The district court first decided subconstitutionally that the government's new detention policy was invalid because it had not been adopted properly under the Administrative Procedure Act (APA). ${ }^{237}$ The effect was to restore the old policy, under which the plaintiffs were entitled to be released. ${ }^{238}$ The court also extensively discussed the constitutional equal protection issue. In constitutional reasoning that reflected a phantom equal protection norm, the court distinguished claimants seeking parole from those seeking admission, citing Yick Wo, Wong Wing, Mathews v. Diaz, as well as the lower court decision that the Supreme Court later affirmed in Plyler v. Doe. ${ }^{239}$ Ultimately, however, the court found that plaintiffs had failed to show a constitutional violation, leaving the decision to stand on the subconstitutional ground alone. $^{240}$

On review, an Eleventh Circuit panel concurred with the district court's constitutional dictum that the plenary power doctrine did not apply because plaintiffs sought parole, not admission. ${ }^{241}$ The panel relied on Yick Wo and Plyler v. Doe, on Plasencia, as well as on a phantom norm decision, Chew. ${ }^{242}$ Like the district court, the panel actually reached only a subconstitutional decision, but it went beyond simply affirming the district court's finding of

236. Id. at 212 n.12.

237. Louis v. Nelson, 544 F. Supp. 973, 993-97 (S.D. Fla. 1982), aff'd in part sub nom. Jean v. Nelson, 711 F. 1455 (11th Cir. 1983), rev'd, 727 F.2d 957 (11th Cir. 1984) (en banc), aff'd as modified, 472 U.S. 846 (1985).

238. 544 F. Supp. at 1006 . The district court stayed its order for 30 days, during which the RS promulgated a new parole policy in compliance with the APA.

239. See id. at 998 ("[w] $[\mathrm{w}$. requesting release on parole, Plaintiffs are entitled to the same constitutional protections afforded all persons within the territorial jurisdiction of the United States"); see also id. at 990 (citing Diaz, 426 U.S. at 77, for proposition that plaintiffs "are persons within the territorial jurisdiction of the United States and they cannot be denied their liberty without due process of law").

240. 544 F. Supp. at $998-1002$ (evidence shows no equal protection violation).

241. Jean v. Nelson, 711 F.2d 1455, 1484 (11th Cir. 1983), rev'd, 727 F.2d 957 (11th Cir. 1984) (en banc), aff' $d$ as modified, 472 U.S. 846 (1985); see also Shaughnessy v. United States ex rel. Mezei, 345 U.S. 206, 220 (1953) (Jackson, J., dissenting) ("Realistically, this man is incarcerated by a combination of forces which keep him as effectually as a prison, the dominant and proximate cause of these forces being the United States immigration authority."); id. at 227 ("Confinement is no longer ancillary to exclusion; it can now be justified only as the alternative to normal exclusion. It is an end in itself."). $c f$. Bertrand v. Sava, 535 F. Supp. 1020, 1030 (S.D.N.Y. 1982) ("There comes a point at which 'temporary' detention takes on the aura of permanence."), rev'd on other grounds, 684 F.2d 204 (2d Cir. 1982).

242. 711 F.2d at 1483-85. The court also relied on Rodriguez-Fernandez v. Wilkinson, 654 F.2d 1382 (10th Cir. 1981), a phantom norm decision that is discussed in greater detail infra text accompanying notes 256-65. 
noncompliance with the APA. ${ }^{243}$ It reached a second subconstitutional holding based on a phantom equal protection norm-whether or not the plenary power cases barred plaintiffs from raising a constitutional equal protection claim, the statute prohibited discrimination. ${ }^{244}$ The panel went on to decide that plaintiffs had proved unlawful discrimination. ${ }^{245}$

The Eleventh Circuit en banc also spoke subconstitutionally, but it was unwilling to use abuse of discretion analysis as a vehicle for expressing phantom equal protection norms not indigenous to immigration law. ${ }^{246}$ Unsurprisingly, it found no defects, forcing it to reach the constitutional issue. Flatly disagreeing with the constitutional dicta in the district court and the panel opinions, the court en banc held that aliens have no greater right to seek parole than to seek admission. ${ }^{247}$ Reasoning that Mezei compelled rejection of plaintiffs' constitutional claims, ${ }^{248}$ it upheld the detention policy. Four judges dissented in an opinion that adopted the panel decision's view that the statute prohibited discrimination, whether the Constitution did or not. ${ }^{249}$

The Supreme Court, like all three lower courts, addressed the subconstitutional issue. Noting that the parole regulations were "facially neutral" and that the parties all believed them to require "parole decisions to be made without regard to race or national origin,"250 the Court found that the statute and regulations barred any race or national origin discrimination against the Haitians. Unlike the lower courts, the Court declined to address the constitutional issue and criticized the Eleventh Circuit en banc opinion for

243. 711 F.2d at 1474-83.

244. Id. at 1485 ("Our standard of review under Mezei and Knauff is to assure aliens receive that process Congress determined was due; on the record before us we can but determine that Congress intended the statutes under which the INS acted to be applied in a non-discriminatory fashion."). For cases basing similar subconstitutional results on international law, see Haitian Refugee Center v. Civiletti, S03 F. Supp. 442, 453-54 (S.D. Fla. 1980), aff'd as modified sub nom. Haitian Refugee Center v. Smith, 676 F.2d 1023, 1038 n.35 (5th Cir. Unit B 1982); Sannon v. United States, 427 F. Supp. 1270, 1274-77 (S.D. Fla. 1977), vacated and remanded without opinion, 566 F.2d 104 (5th Cir. 1978). But $c f$. Bertrand v. Sava, 684 F.2d 204, 218-19 (2d Cir. 1982) (international law does not change status under domestic law); Pierre v. United States, 547 F.2d 1281 (5th Cir. 1977) (same), vacated and remanded to consider mootness, 434 U.S. 962 (1977).

245. 711 F.2d at 1501-02.

246. Jean v. Nelson, 727 F.2d 957, 975-79 (11th Cir. 1984) (en banc), aff' $d$ as modified, 472 U.S. 846 (1985) ("both executive and congressional actions are to be regulated by the judiciary according to the same narrow standard of review"); id. (immigration officials were "acting within the scope of their delegated powers"); see also Bertrand v. Sava, 684 F.2d 204, 217 (2d Cir. 1982); Pierre v. United States, 547 F.2d 1281, 1289 (5th Cir. 1977), vacated and remanded to consider mootness, 434 U.S. 962 (1977). Jean is a variation on the standard abuse of discretion case because lower level INS officials may have failed to follow internal INS guidelines. The Eleventh Circuit en banc remanded this question to the district court. 727 F.2d at $978-79$.

247. 727 F.2d at 963 ("decision to parole or detain an excludable alien is an integral part of the admissions process"); see also id. at 969 ("alien's legal status is not altered by detention or parole"); Bertrand v. Sava, 684 F.2d 204, 211-12 (2d Cir. 1982).

248. 727 F.2d at $969-72$.

249. Id. at 987-89 (Kravitch, J., concurring in part and dissenting in part).

250. 472 U.S. 846,852 (1984). The regulation at that time was 8 C.F.R. $\$ 212.5$ (1982). The current regulation is 8 C.F.R. $\$ 212.5$ (1990). See 47 Fed. Reg. 30,044 (1982), (as amended at 47 Fed. Reg. 46,493 (1982)); see also 8 C.F.R. $\S \S 212.12,212.13,235.3$ (1990). 
having done so..$^{251}$ It remanded the case to the district court to decide whether INS officials had made individualized parole determinations in exercising their statutory discretion, and whether they had acted without regard to race or national origin. ${ }^{252}$

In dissent, Justice Marshall correctly observed that nothing in the statute or regulations expressly prohibited consideration of race or national origin in parole decisions, notwithstanding any stipulation by the parties. ${ }^{253}$ The parties to the litigation and all three lower court opinions had viewed any such possible restrictions as constitutional in nature, drawn from the Yick Wo tradition. ${ }^{254}$ The Court could have expressed that reasoning directly in constitutional terms, but had it done so, the Court would have significantly limited the plenary power doctrine, especially as set out in Knauff and Mezei. Such a constitutional decision would have done for equal protection challenges by asylum applicants what Plasencia had done for procedural due process claims by reentering permanent residents. Of course, the Court could have taken that step, but as in Chew, it was unwilling to do so. As long as it would not decide Jean on constitutional grounds, the antidiscrimination norm that guided the Court's interpretation of the parole statute and regulations remained a phantom. This characterization fits not only the Supreme Court's reasoning in Jean, but also the reasoning of the lower courts-none of which had the power even to consider overruling or limiting Knauff or Mezei-in Jean and in the other discrimination cases discussed here.

251. 472 U.S. at $854-55$.

252. Id. at 857 .

253. Id. at 861 (Marshall, J., dissenting) ("[the regulations] do not, by their terms, prohibit the consideration of race or national origin"). Interestingly, Justice Marshall's dissent focused almost entirely on national origin discrimination, which he seemed to regard as sufficient to undermine the majority's position. See, e.g., id. at 864 ("[T]he Court's conclusion that, aside from constitutional constraints, the parole regulations prohibit national-origin distinctions draws no support from anything in the regulations themselves or in the statutory and administrative background to those regulations."). In a footnote, he observed without explanation that "the analysis would be different for race discrimination." $1 d$. at $859 \mathrm{n} .1$. In fact, the statute and regulations address neither race nor national origin discrimination. I intend my analysis of Jean as a phantom norm decision to include both race and national origin, but the analysis would remain valid even based on only one of the two.

The statute makes parole highly discretionary. See id. at 863 (Marshall, J., dissenting) ("These regulations indicate that the INS believes that nationality-based distinctions are not necessarily inconsistent with congressional delegation of 'discretion' over immigration decisions to the Executive. That interpretation of the statutes is, of course, entitled to deference.") (citing Chevron); see also id. at 865; $c f$. Haitian Refugee Center v. Civiletti, 503 F. Supp. 442, 453 (S.D. Fla. 1980) (congressional conclusion that discrimination in immigration law is "improper" is evident in DNA $\S 202$ (a), 8 U.S.C. $\S 1152$ (a): "No person shall receive any preference or priority or be discriminated against in the issuance of an immigrant visa because of his race, sex, nationality, place of birth, or place of residence ... ."), aff'd as modified sub nom. Haitian Refugee Center v. Smith, 676 F.2d 1023 (5th Cir. Unit B 1982).

The rest of Marshall's dissent addressed the constitutional issue directly. 472 U.S. at 868-81 (aliens have constitutional right to parole decisions free of race or national origin discrimination) (citing Yick Wo, Wong Wing, Russian Volunteer Fleet, Diaz, and Plyler); see also id. at 877-79 (granting parole to aliens, at least while decision on their excludability is pending, differs from admitting them).

254. See Louis v. Nelson, 544 F. Supp. at 998; Jean v. Nelson, 711 F.2d at 1483-85; Jean v. Nelson, 727 F.2d at $967-75$. 
It is striking that the racial equality aspect of this norm was the same norm that had influenced the Court's interpretation of the tax exemption statute in Bob Jones. ${ }^{255}$ Both Bob Jones and Jean arose because the agency had to decide whether, in enforcing the statute, to apply a racial equality norm that Congress had not expressly specified. In Bob Jones, the racial equality norm was real, but in Jean it was phantom; the Court has never held an immigration classification unconstitutional on the ground that it discriminates on the basis of race or national origin.

\section{Indefinite Detention of Mariel Cubans}

Another group of phantom norm cases involves Mariel Cubans, about 125,000 of whom came to the United States from Cuba between April and October 1980. While many were excludable, the Cuban government would not take them back, and the United States government then placed many in indefinite detention. ${ }^{256}$ In Rodriguez-Fernandez v. Wilkinson, ${ }^{257}$ one detainee sought release on parole, claiming that continued indefinite detention was cruel and unusual punishment proscribed by the Eighth Amendment and a violation of the due process clause of the Fifth Amendment. In 1980, the district court found that the petitioner could not claim rights under the Fifth or Eighth Amendments, and that denying parole offended no statute, but that such a denial nonetheless constituted an abuse of discretion because it violated international law principles forbidding arbitrary detention. ${ }^{258}$

In 1981, a Tenth Circuit panel affirmed on the subconstitutional ground that the INS lacked statutory authority for indefinite detention. ${ }^{259}$ But the heart of the opinion's reasoning was dictum, based on a phantom norm of Fifth and Eighth Amendment protections for detained would-be entrants that would render indefinite detention of these excludable Cubans unconstitutional punishment. ${ }^{260}$ The panel conceded that the plenary power cases, especially Mezei,

255. Bob Jones is discussed supra text accompanying notes 78-83.

256. For background, see 52 Fed. Reg. 48,799-802 (1987); Note, Legal Fictions Mask Human Suffering: The Detention of the Mariel Cubans-Constitutional, Statutory, International Law, and Human Considerations, 62 S. CAL. L. REV. 1733, 1735-43 (1989). Under the Cuban Review Plan adopted on May 25, 1987, Mariel Cubans still in custody receive an annual INS interview to determine whether they will be released on parole. The detainees must show that they are nonviolent and likely to remain so, not likely to commit future crimes, do not pose a danger to the community, and are not likely to violate parole conditions. See 8 C.F.R. $\S 212.12$ (1990). After prison riots in Atlanta, Georgia, and Oakdale, Louisiana, in November 1987, the government agreed that Cubans in custody at that time also would receive a one-time written review by a special Department of Justice panel (from which INS personnel are excluded) if they were denied parole by the INS. See 8 C.F.R. $\$ 212.13$ (1990).

257. Fernandez v. Wilkinson, 505 F. Supp. 787 (D. Kan. 1980), aff'd sub nom. Rodriguez-Fernandez v. Wilkinson, 654 F.2d 1382 (10th Cir. 1981).

258. 505 F. Supp. at $790-800$.

259. 654 F.2d at 1389-90 (construing INA $\S 233,8$ U.S.C. $\S 1223$ (b), repealed by $\S 206$, Act of Oct. 30, 1986, Pub. L. No. 99-591, 100 Stat. 3341-56).

260. 654 F.2d at 1386 ("We dispose of the appeal by construing the applicable statutes to require Rodriguez-Fernandez' release at this time. Nevertheless, it seems important to discuss the serious constitutional 
normally insulate exclusion decisions from constitutional challenges, but it concluded that indefinite detention was not just incident to exclusion, and instead that it closely resembled criminal punishment. ${ }^{261}$ This analysis relied on Yick Wo and four of its most prominent progeny-Wong Wing, Russian Volunteer Fleet, Mow Sun Wong, and Graham. ${ }^{262}$ The panel distinguished Mezei in four ways: it focused on denial of a hearing, it involved national security considerations, it involved confinement under less harsh conditions, and it raised a claim of not only parole but also admission. ${ }^{263}$

The court based its subconstitutional decision on constitutional reasoning. The opinion offered a questionable interpretation of the statute ${ }^{264}$ and resulted in a surreal order that the INS release an excludable alien, but not necessarily within the United States. The court offered this reading with little discussion, but observed that the reading was consistent with the court's constitutional analysis. ${ }^{265}$ In Diaz v. Haig, ${ }^{266}$ the federal district court in Wyoming followed Rodriguez-Fernandez and relied on Yick Wo and Wong Wing in reaching alternative findings that indefinite detention of juvenile Cubans was abuse of discretion and a Fifth Amendment due process violation. ${ }^{267}$ Other cases have reached similar subconstitutional holdings, though the extent to which they relied on constitutional reasoning varies. ${ }^{268}$ That the subconstitutional analysis

questions involved if the statute were construed differently.").

261. Id. at 1385-86.

262. Id. at 1386-87. These cases are discussed supra text accompanying notes 95-100, 194-209.

263. Id. at 1388. The focus on denial of a hearing in Mezei was indeed a difference between the facts in $M e z e i$ and Chew, but one that would seem to strengthen it as a barrier against the Cubans' claims in Rodriguez-Fernandez.

264. For a critique of the court's interpretation of the statute, see Note, Statutory and Constitutional Limitations on the Indefinite Detention of Excludable Aliens, 62 B.U.L. REV. 553, 570-79 (1982).

265. 654 F.2d at 1390.

266. 594 F. Supp. 1 (D. Wyo. 1981).

267. Id. at 5-6 (abuse of discretion), 7-8 (due process).

268. See Moret v. Karn, 746 F.2d 989, 992 (3d Cir. 1984) (abuse of discretion to deny parole without dangerousness finding required by INS internal procedures); Fernandez-Roque v. Smith, 557 F. Supp. 690, 696 (N.D. Ga. 1982) (some sponsorship practices were abuse of discretion; other parole-related policies are not), rev'd, 734 F.2d 576, 583 (11th Cir. 1984) (applying same abuse of discretion test but reaching opposite result); Soroa-Gonzales v. Civiletti, 515 F. Supp. 1049, 1057-61 (N.D. Ga. 1981) (abuse of discretion for INS to revoke parole); $c f$. Gutierrez v. Ilchert, 702 F. Supp. 787, 789-94 (N.D. Cal. 1988) (denial of parole to IRCA legalization applicant lacks facially legitimate and bona fide reason); Gutierrez v. Ilchert, 682 F. Supp. 467, 471-72 (N.D. Cal. 1988) (denial of parole to IRCA legalization applicant is abuse of discretion and lacks facially legitimate and bona fide reason). See generally Note, supra note 256. But cf. Perez-Perez v. Hanberry, 781 F.2d 1477, 1481-82 (11th Cir. 1986) (broad discretion to grant or deny parole); Sidney v. Howerton, 777 F.2d 1490, 1491 (11th Cir. 1985) (vacating district court order to parole alien during pendency of habeas corpus petition); Note, Indefinite Detention of Excluded Aliens: Statutory and Constitutional Justifications and Limitations, 82 MICH. L. REV. 61, $65-76$ (1983) (statute allows detention instead of parole).

At least one court relied on international law. A gravitational pull on statutes may be exercised by international law norms, which, like phantom constitutional norms, are inconsistent with prevailing constitutional law. See, e.g., Fernandez v. Wilkinson, 505 F. Supp. 787, 795-800 (D. Kan. 1980), aff'd on other grounds sub nom. Rodriguez-Fernandez v. Wilkinson, 654 F.2d 1382 (10th Cir. 1981); Eskridge, supra note 74, at 1026-28. But see Amanullah v. Nelson, 811 F.2d 1, 16 n.10 (1st Cir. 1987); Singh v. Nelson, 623 F. Supp. 545, 552-58 (S.D.N.Y. 1985); Fernandez-Roque v. Smith, 567 F. Supp. 1115, 1122 n.2 (N.D. Ga. 1983), rev'd on other grounds, 734 F.2d 576 (11th Cir. 1984); Fernandez-Roque v. Smith, 622 F. Supp. 
in these cases rested on a phantom norm is evident not only from Mezei itself, but also from other appellate decisions that have consistently rejected Fifth and Eighth Amendment protections for indefinitely detained Cubans. For example, in Fernandez-Roque v. Smith ${ }^{269}$ an Eleventh Circuit panel squarely reversed a district court decision that started its analysis with Yick Wo and ended by adopting reasoning similar to the constitutional dictum in Rodriguez-Fernandez. ${ }^{270}$ Relying heavily on the en banc decision in Jean $v$. Nelson, ${ }^{271}$ the panel followed Mezei in holding that decisions regarding release from detention on parole are within the political branches' plenary power because they are part of the admissions process. ${ }^{272}$

\section{Asylum Procedures for Excludable First-Time Entrants}

Several recent lower court cases on procedures for deciding asylum applications by excludable first-time entrants are probably subconstitutional decisions guided by phantom constitutional norms. In Chun v. Sava, ${ }^{273}$ decided in 1983, a Second Circuit panel interpreted the asylum statutes and regulations to require the INS to grant stowaways an exclusion hearing at which they could raise asylum claims. Augustin v. Sava, ${ }^{274}$ a 1984 Second Circuit panel decision, interpreted the asylum statutes and regulations to require adequate translations. Both interpretations relied heavily on a constitutional norm of due process for excludable first-time entrants seeking asylum, and in particular on the view that the scheme for granting political asylum creates a constitutionally protectable liberty or property interest that brings asylum applicants within the procedural due process framework set out in Goldberg v. Kelly, ${ }^{275}$ Mathews $v$. Eldridge, ${ }^{276}$ and their progeny. Chun's subconstitutional analysis relied heavi-

887, 901-04 (N.D. Ga. 1985), aff'd in pertinent part and rev'd in part on other grounds sub nom. Garcia-Mir v. Meese, 788 F.2d 1446, 1453-55 (11th Cir.), cert. denied, 479 U.S. 888 (1987); Ishtyaq v. Nelson, 627 F. Supp. 13, 17-26 (E.D.N.Y. 1983). On international law as it applies to exclusion, see Nafziger, The General Admission of Aliens Under International Law, 77 AM. J. INT'L L. 804 (1983).

269. 734 F.2d 576 (11th Cir. 1984), rev'g 567 F. Supp. 1115 (N.D. Ga. 1983).

270. See 567 F. Supp. at 1125-29 (detention was not merely incident to exclusion, and judicially ordered parole was provisional procedural remedy separate from substantive admission decisions).

271. 727 F.2d 957 (11th Cir. 1984) (en banc), aff'd as modified, 472 U.S. 846 (1985), discussed supra text accompanying notes 237-55.

272. Fernandez-Roque, 734 F.2d at 581-82; see also Mezei, 345 U.S. at 215 ("such temporary harborage, an act of legislative grace, bestows no additional rights"); Carlson v. Landon, 342 U.S. 524, 533 (1952) ("Detention is necessarily a part of this deportation procedure."); Amanullah, 811 F.2d at 9-11; Garcia-Mir v. Meese, 766 F.2d 1478, 1484 (11th Cir. 1985), cert. denied, 475 U.S. 1022 (1986); Palma v. Verdeyen, 676 F.2d 100, 103-05 (4th Cir. 1982); Fernandez, 505 F. Supp. at 790. See generally Schuck, supra note 6, at 71 ("As a practical matter, this ostensibly procedural decision amounts to granting a substantive right to remain in this country indefinitely to many aliens who are clearly excludable under our laws.") (emphasis in original); id. at 30 (classical immigration law treated exclusion and detention alike); id. at 28-30, 68-72 (detention power is key to classical immigration law).

273. 708 F.2d 869 (2d Cir. 1983).

274. 735 F.2d 32 (2d Cir. 1984).

275. 397 U.S. 254 (1970).

276. 424 U.S. 319 (1976). 
ly on "the dictates of procedural due process" and the presence of a constitutionally "protectable interest."277 Similarly, Augustin cited Mathews v. Diaz for the proposition that "an alien who is present in the United States, even illegally, is entitled to constitutional protections." 278 It then noted that its interpretation of the statute and regulations may very likely be the constitutional due process minimum, because of asylum applicants' "constitutionally protected liberty or property interests."279

The constitutional norm of due process for excludable first-time entrants seeking asylum was probably a phantom. Plasencia embraced the Mathews $v$. Eldridge procedural due process analysis, but only for returning permanent residents. ${ }^{280}$ Lower courts have imposed some modest procedural due process requirements in asylum cases, but for deportable rather than excludable aliens. $^{281}$ The Eleventh Circuit's 1982 panel decision in Haitian Refugee

277. 708 F.2d at 876 ("our construction of the statute is aided to some extent, if not guided, by what we perceive to be the dictates of procedural due process"); $i d$. at $877 \& \mathrm{n} .25$ ("refugee who has a "wellfounded fear of persecution' in his homeland has a protectable interest recognized by both treaty and statute, and his interest in not being returned may well enjoy some due process protection not available to an alien claiming only admission").

278. 735 F.2d at 36.

279. Id. at 37; see also id. ("procedural protections may well be required not only by the pertinent statutes and regulations but also by the due process clause"); $i d$. ("likely that some due process protection surrounds the determination of whether an alien has sufficiently shown that return to a particular country will jeopardize his life or freedom"); $i d$. at 38 ("appellant was denied procedural rights protected by statute and INS regulations and very likely by due process as well"). Justice Marshall's dissent in Jean noted that "the Court of Appeals for the Second Circuit has suggested that unadmitted aliens can invoke the protections of the Constitution." 472 U.S. at 868 n.8 (Marshall, J., dissenting) (citing Augustin and Chun).

280. See 459 U.S. 21, 34 (1982). Plasencia is discussed in greater detail supra text accompanying notes 175-81.

281. See Orantes-Hernandez v. Meese, 685 F. Supp. 1438, 1506-08 (C.D. Cal. 1988) (under Constitution and Eldridge analysis, government must give notice of right to apply for asylum); id. at 1509-11 (government may not interfere with access to retained counsel in asylum cases); Orantes-Hernandez v. Smith, 541 F. Supp. 351, 374-78, 380-82 (C.D. Cal. 1982) (similar). The court recently found that the INS failed to comply with a permanent injunction ordering better access to legal services. Orantes-Hernandez v. Thornburgh, CV 82-1107 KN (C.D. Cal. Sept. 28, 1989), digested in 66 INTERPRETER RELEASES 1177-78 (1989); see also Nunez v. Boldin, 537 F. Supp. 578, 583-87 (S.D. Tex. 1982) (identifying the interests as "life and liberty," court issued temporary restraining order requiring government to notify detainees of right to apply for asylum), appeal dismissed, 692 F.2d 755 (5th Cir. 1982); $c f$. Haitian Refugee Center v. Nelson, 872 F.2d 1555, 1562-63 (11th Cir. 1989) ("entitlement interest exists"; Constitution requires certain procedures for Special Agricultural Worker legalization), aff'g Haitian Refugee Center v. Nelson, 694 F. Supp. 864, 878 (S.D. Fla. 1988) ("constitutionally protected right to seek SAW status"). See generally Note, INS Transfer Policy: Interference With Detained Aliens' Due Process Right to Retain Counsel, 100 HARV. L. REV. 2001 (1987).

The Orantes-Hernandez litigation also includes subconstitutional holdings that may reflect a constitutional due process norm, but for deportable aliens this norm may not be a phantom. See Orantes-Hernandez v. Meese, 685 F. Supp. 1488, 1506, 1509 (C.D. Cal. 1988); Orantes-Hernandez v. Smith, 541 F. Supp. 351, 374-76 (C.D. Cal. 1982) (similar). But cf. Azzouka v. Sava, 777 F.2d 68, 75-76 (2d Cir. 1985) (statute gives no right to asylum hearing if government finds alien is national security risk), cert. denied, 479 U.S. 830 (1986); see also Azzouka v. Sava, 820 F.2d 585 (2d Cir. 1987). In what may be a similar phantom norm decision, a district court held recently that the government's failure to interpret entire deportation and exclusion proceedings for non-English speakers violates their statutory rights to be present, examine evidence, confront and cross-examine witnesses, as well as their constitutional Fifth Amendment due process rights. El Rescate Legal Servs. v. Executive Office of Immigration Review, 727 F. Supp. 557, 560-63 (C.D. Cal. 1989); cf. Sannon v. United States, 427 F. Supp. 1270, 1273, 1275-77 (S.D. Fla. 1977) (relying on United Nations Convention and Protocol Relating to the Status of Refugees to require equal treatment of 
Center $v$. Smith $^{282}$ recognized a constitutionally protected liberty or property interest in asylum applicants who are excludable first-time entrants. ${ }^{283} \mathrm{But}$ $K$ nauff and $M e z e i^{284}$ either squarely block a finding that a first-time entrant applying for asylum has a liberty interest in entry, or compel finding that she is entitled only to minimal due process under the Eldridge analysis. In fact, the Eleventh Circuit has severely limited Haitian Refugee Center v. Smith, if not effectively overruled it. ${ }^{285}$

\section{First Amendment Challenges to Exclusion Grounds}

Another important group of phantom norm cases involves First Amendment challenges to exclusion grounds. ${ }^{286}$ In 1982 , for example, a federal district

excludable and deportable aliens), vacated and remanded without opinion, 566 F.2d 104 (5th Cir. 1978). But see Pierre v. United States, 547 F.2d 1281, $1287-89$ (5th Cir. 1977), vacated and remanded to consider mootness, 434 U.S. 962 (1977). For a discussion of Sannon and Pierre, see Note, Due Process Rights for Excludable Aliens Under United States Immigration Law and the United Nations Protocol Relating to the Status of Refugees-Haitian Aliens, A Case in Point, 10 N.Y.U. J. INT'L L. \& POL. 203 (1977).

282. 676 F.2d 1023 (5th Cir. Unit B 1982).

283. See id. at 1038 ("constitutionally protected liberty or property interests may have their source in positive rules of law, enacted by the state or federal government and creating a substantive entitlement to a particular governmental benefit. In this case we conclude that Congress and the executive have created, at a minimum, a constitutionally protected right to petition our government for political asylum."), aff' $g$ and modifying Haitian Refugee Center v. Civiletti, 503 F. Supp. 442, 455 (S.D. Fla. 1980) ("asylum applicant who fears to return to his homeland because of persecution has raised the specter of truly severe deprivations of life, liberty, and property"). For commentaries adopting this general approach to excludable aliens' due process rights, see Martin, supra note 103, at 187; Note, The Right to Appointed Counsel in Asylum Proceedings, 85 COLUM. L. REV. 1157 (1985); Note, Penetrating the Entry Doctrine: Excludable Aliens' Constitutional Rights in Immigration Processes, 98 YALE L.J. 639 (1989). For a much earlier case that similarly combined phantom constitutional reasoning with a subconstitutional holding, see United States ex rel. Paktorovics v. Murff, 260 F.2d 610, 613-15 (2d Cir. 1958) ("since a construction of [the statute] which requires a hearing on the subject of revocation of parole will remove serious doubt regarding the validity of the statute, we so construe the section").

284. Plasencia limited $M e z e i$, but only with respect to returning permanent residents. See supra text accompanying notes $157-81$.

285. Jean v. Nelson, 727 F.2d 957, 981-83 (11th Cir. 1984) (en banc) (no liberty or property interest in asylum; neither due process nor statute/regulations requires notice of right to seek asylum), rev'g 711 F.2d 1455, 1507-08 (11th Cir. 1983) (aliens in exclusion must be notified of right to seek asylum), aff $d$ as modified, 472 U.S. 846 (1985); cf. Ukrainian-American Bar Ass'n v. Baker, 893 F.2d 1374, 1380-82 (D.C. Cir. 1990) (government need not tell asylum applicants of offer of free legal advice); Perez-Perez v. Hanberry, 781 F.2d 1477, 1479-81 (11th Cir. 1986) (statute does not authorize appointed counsel in habeas corpus action attacking parole denial); Garcia-Mir v. Meese, 788 F.2d 1446, 1449-53 (11th Cir. 1986), (indefinitely detained Cubans have no constitutionally protected liberty interest in parole), cert. denied, 479 U.S. 889 (1986); Fernandez-Roque v. Smith, 734 F.2d 576, 582 (11th Cir. 1984) (same, citing 11 th Circuit en banc opinion in Jean); Ramirez-Osorio v. INS, 745 F.2d 937, 944-47 (5th Cir. 1984) (even assuming that deportation asylum applicant has protectable liberty interest, due process does not require notice of asylum); Avila v. Rivkind, 724 F. Supp. 945, $947-48$ (S.D. Fla. 1989) (alien seeking admission "is requesting a privilege, and has extremely limited constitutional protection"; Attorney General may exclude without further hearing an alien previously convicted for terrorist activities as security risk under INA § 235(c)); Note, Protecting Aliens From Persecution Without Overloading the INS: Should Illegal Aliens Receive Notice of the Right to Apply for Asylum?, 69 VA. L. REV. 901, 908-13 (1983) (even if immigration laws create liberty interest in asylum applicant, no due process right to notice of asylum).

286. American-Arab Anti-Discrimination Comm. v. Meese, 714 F. Supp. 1060 (C.D. Cal. 1989), an important recent case sustaining a First Amendment challenge to ideological deportation grounds, is discussed infra text accompanying notes 352-57. 
court in Lesbian/Gay Freedom Day Committee v. INS ${ }^{287}$ barred the government from enforcing the "psychopathic personality" statutory exclusion ground against homosexuals. ${ }^{288}$ The opinion relied largely on constitutional analysis, specifically a norm of First Amendment limits on government enforcement of the immigration statutes. The court found that because medical authorities no longer considered homosexuality per se to be a mental disorder, applying this exclusion ground to homosexuals was unconstitutional under the First Amendment and Mandel's "facially legitimate and bona fide" test. ${ }^{289}$ But Mandel itself tells us that the district court in Lesbian/Gay Freedom Day Committee relied on a phantom norm. There, the Supreme Court dismissed a First Amendment claim by finding that the government had given a "facially legitimate and bona fide reason," without background inquiry of the sort in Lesbian/Gay Freedom Day Committee. ${ }^{290}$ The only other federal court of appeals to consider a similar constitutional challenge upheld enforcement. ${ }^{291}$ And because of the Supreme Court decision in Boutilier v. INS, ${ }^{292}$ any constitutional challenge on vagueness grounds would be no less based on phantom norm reasoning.

Lesbian/Gay Freedom Day Committee merits description as a subconstitutional decision based on a phantom constitutional norm, because its constitutional reasoning also provided the basis for its alternative subconstitutional holding - that enforcement of the "psychopathic personality" exclusion ground against homosexuals was an abuse of discretion because it was inconsistent with the statute. ${ }^{293} \mathrm{By}$ transplanting the "facially legitimate and bona fide reason" test to subconstitutional ground, using it to ask if government action was "beyond the scope of delegated powers" or an "abuse of discretion," the court expressed its constitutional views in a much less audacious form and gave new, subconstitutional life to First Amendment challenges. Indeed, the Ninth Circuit affirmed on the statutory ground without reaching the constitutional issue. $^{294}$

Several similar decisions involve First Amendment challenges to government decisions to exclude aliens on openly ideological grounds, as authorized

287. 541 F. Supp. 569 (N.D. Cal. 1982), aff'd only on statutory ground sub nom. Hill v. INS, 714 F.2d 1470,1481 (9th Cir. 1983).

288. INA § 212(a)(4), 8 U.S.C. § 1182(a)(4) (1988), discussed supra text accompanying notes 158-73 in connection with Rosenberg v. Fleuti, 374 U.S. 449 (1963).

289. 541 F. Supp. at $585-88$.

290. Kleindienst v. Mandel, 408 U.S. 753 (1972), is discussed in greater detail supra text accompanying notes 182-87.

291. Matter of Longstaff, 716 F.2d 1439, 1442-43, 1450 n.56 (5th Cir. 1983), cert. denied, 467 U.S. 1219 (1984).

292. 387 U.S. 118 (1967), discussed supra text accompanying note 172 in connection with Rosenberg v. Fleuti, 374 U.S. 449 (1963).

293. 541 F. Supp. at 580; see also Note, The Immigration and Nationality Act and the Exclusion of Homosexuals: Boutilier v. INS Revisited, 2 CARDOZO L. REV. 359 (1981). But cf. Matter of Longstaff, 716 F.2d 1439, 1445-51 (5th Cir. 1983) (no subconstitutional problem with enforcement of exclusion ground against homosexuals), cert. denied, 467 U.S. 1219 (1984).

294. Hill v. INS, 714 F.2d 1470, 1481 (9th Cir. 1983). 
by statute. ${ }^{295}$ Allende v. Shultz, ${ }^{296}$ a 1985 district court case, challenged denial of a nonimmigrant visa to Hortensia Allende, widow of former Chilean President Salvador Allende. Allende resembles Lesbian/Gay Freedom Day Committee in that it also turned Mandel's "facially legitimate and bona fide reason" test for constitutional challenges into a subconstitutional reason to deny the government's motion to dismiss or in the alternative for summary judgment. According to the court, "the explanation given must be "facially legitimate and bona fide' not only in a general sense, but also within the context of the specific statutory provision on which the exclusion is based."297 A later opinion in the same case reached the same conclusion after considering new evidence, and suggested strongly that its holding on both occasions was a matter of statutory interpretation. ${ }^{298}$ El-Werfalli v. Smith, ${ }^{299}$ a 1982 district court decision, is similar in reasoning though not result. The court applied the "facially legitimate and bona fide reason" test as part of an analysis that probably was subconstitutional, in that it measured whether the stated reason conformed to the exclusion ground as set forth in the statute. The court tentatively found that the government "arguably fail[ed] to establish a reasoned basis for action," but then later found for the government after in camera inspection of classified material. ${ }^{300}$

Abourezk v. Reagan, ${ }^{301}$ the only recent federal appellate decision involving a First Amendment challenge to ideological exclusion, may also be an example of phantom norm decisionmaking. Without clearly separating its constitutional and subconstitutional analyses, ${ }^{302}$ the district court first interpreted the statute

295. See INA § 212(a)(27), (28), (29), 8 U.S.C. § 1182(a)(27), (28), (29) (1988).

296. 605 F. Supp. 1220 (D. Mass. 1985), aff'd, 845 F.2d 1111 (1st Cir. 1988).

297. 605 F. Supp. at 1224, aff' $d, 845$ F.2d 1111 (1st Cir. 1988); $c f$. Gutierrez v. Ilchert, 702 F. Supp. 787, 789-95 (N.D. Cal. 1988) (denial of parole to IRCA legalization applicant lacks facially legitimate and bona fide reason); Gutierrez v. Ilchert, 682 F. Supp. 467, 471-72 (N.D. Cal. 1988) (denial of parole to IRCA legalization applicant is abuse of discretion and lacks facially legitimate and bona fide reason). But $c f$. Bertrand v. Sava, 684 F.2d 204, 210-13 (2d Cir. 1982) ("facially legitimate and bona fide reason," not abuse of discretion test, applies to attack on parole denial as impermissibly based on race and/or national origin).

298. See Allende v. Shultz, No. 83-3984-C, slip op. at 71987 LEXIS 2798, 15 (D. Mass. Mar. 31, 1987) ("This Court [earlier] ruled that under subsection 27, Mrs. Allende's mere membership in [certain communist organizations] was an insufficient reason for the denial of her visa application."); see also id. at 16 ("There is thus no lawful basis for defendants, proceeding under subsection 27."). In February 1990, Pub. L. No. 101-246, § 128, 104 Stat. 15, made permanent $\$ 901$ of the Foreign Relations Authorization Act, Pub. L. No. 100-204, which barred the government from deporting, excluding, or denying visas to nonimmigrants because of past or current political beliefs, statements or associations which, if engaged in by a citizen in this country, would be protected by the Constitution. Section 128 also makes it clear that entry by nonimmigrants protected under $\$ 901$ cannot be subject to conditions or restrictions.

299. 547 F. Supp. 152 (S.D.N.Y. 1982).

300. Id. at 154. The Allende opinion, 605 F. Supp. at 1224, aff d, 845 F.2d 1111 (1st Cir. 1988), cited El-Werfalli; see also NGO Comm. on Disarmament v. Haig, No. 82 Civ. 3636, slip op. (S.D.N.Y. June 10, 1982), aff'd mem., 697 F.2d 294 (2d Cir. 1982).

301. 592 F. Supp. 880 (D.D.C. 1984), rev'd and remanded on other grounds, 785 F.2d 1043 (D.C. Cir. 1986), aff' $d$ by an equally divided Court, 484 U.S. 1 (1987).

302. See 592 F. Supp. at 884 n.11 (plaintiffs' arguments that statute either does not permit exclusion or if it does is unconstitutional "do not differ materially, and . . . therefore will be considered together"). 
to permit the visa refusals in question. ${ }^{303}$ It then acknowledged the seriousness of the First Amendment challenge, but rejected it after in camera inspection of classified material. ${ }^{304} \mathrm{~A}$ District of Columbia Circuit panel reversed on the ground that the record in the district court had been inadequate to support its interpretation of the statute. ${ }^{305}$ It remanded the case, avoiding the constitutional issue altogether. ${ }^{306}$ The district court then resolved the case by interpreting the statute as not authorizing the exclusions. ${ }^{307}$ It may be fair to analyze the combined result of these two decisions as judicial review of visa refusals through narrow interpretation of the statutory exclusion grounds, based on a phantom norm of First Amendment limits on government enforcement of the immigration statutes.

\section{IN SEARCh OF CONSTTtutional ImMigration LaW}

In spite of the Court's reluctance to provide guidance in Jean v. Nelson, or perhaps because of it, public debate about plenary power will intensify rather than abate. One problem with this debate is that it has focused almost exclusively on the doctrine's most immediate and obvious consequences, asking simply if it is fair or necessary to keep immigration law outside our system of public law. But it is just as important to examine the plenary power doctrine's less obvious, systemic effects on immigration law as a whole.

\section{A. The Problem of Awkward or Unpredictable Subconstitutional Solutions}

Phantom norm decisions have eliminated some troubling results produced by the plenary power doctrine; this is why courts have reached them. Courts that find acceptable subconstitutional solutions for individual cases will adopt them. Yet a subconstitutional decision can be a very awkward way to express a phantom constitutional norm, because statutes and other subconstitutional texts provide judges with limited interpretive possibilities. These might suffice to prevent injustice in a particular case but do little to find a coherent and fully satisfactory solution if the particular injustice is merely symptomatic of a more fundamental problem that is rooted in the alien's inability, attributable to the plenary power doctrine, to raise a constitutional claim directly. ${ }^{308}$

303. 592 F. Supp. at 884-86. The exclusion ground principally at issue was INA $\$ 212(a)(27), 8$ U.S.C. $\S 1182(a)(27)$ (1988); also important was the relationship between this ground and INA \& 212(a)(28), 8 U.S.C. $\$ 1182(a)(28)(1988)$.

304. 592 F. Supp. at $886-88$.

305. 785 F.2d at 1053-60.

306. Id. at $1060 \mathrm{n.24}$; $c$. id. at 1075-76 (Bork, J., dissenting) (Mandel lets government exclude based on content of political beliefs as constitutional matter).

307. Abourezk v. Reagan, Nos. 83-3739, 83-3741, 83-3895 1988 LEXIS 5203, 15-17 (D.D.C. June 7, 1988).

308. Legislative options are more promising. Congressman Mazzoli offered legislation in recentsessions that would have amended the INA to recognize a returning resident's ties to the United States, much as 
Awkwardness includes both overbreadth and underinclusiveness. Fong Haw $\operatorname{Tan}^{309}$ illustrates the former. Concern for permanent residents prompted the Court to adopt a generous rule of construction that has been applied to all deportation cases. ${ }^{310}$ Both underinclusiveness and overbreadth are evident in Fleuti $i^{311}$ which created an exception to the reentry doctrine because the statute failed to reflect a returning permanent resident's "stake." Fleuti's subconstitutional solution is underinclusive in that many permanent residents, like Maria Plasencia, have significant equities based on ties to this country, but do not benefit from Fleuti. Their problems required the direct constitutional solution in Landon v. Plasencia. ${ }^{312}$ Fleuti is also overinclusive; at least one court has applied it to help nonimmigrants. ${ }^{313}$ Underinclusiveness means some of the problem remains unsolved. Overbreadth represents waste; courts may compensate for the overbroad generosity of Fong Haw Tan, Fleuti, and similar decisions with a more begrudging attitude toward permanent residents on other issues, both constitutional and subconstitutional.

A related problem is unpredictability. The problem arises because sometimes, in Fleuti for example, a subconstitutional decision can incorporate a phantom constitutional norm only by going beyond reasonable readings of a subconstitutional text. Phantom norm decisionmaking may help some aliens when a case evokes sympathy, but we cannot predict those situations. The Supreme Court's 1984 decision in INS v. Phinpathy $a^{314}$ illustrates the problem. The Attorney General has discretion to suspend deportation and confer permanent residency on an otherwise deportable alien of "good moral character" who "has been physically present in the United States for a continuous period of not less than seven years," if deportation would result in "extreme hardship" to the alien or his spouse, parent, or child. ${ }^{315}$ Applying Fleuti by analogy, some lower courts disregarded "innocent, casual, and brief" 316 ab-

happens in constitutional immigration law after Plasencia. H.R. 4823, 99th Cong., 2d Sess. $§ 101$ (1986). This bill passed the House, but the Senate did not act on it. 132 CoNG. REC. H8570 (1986). Mazzoli introduced virtually the same measure the next term, see H.R. 2921, 100th Cong., 1st Sess. (1987). Another option is to eliminate the concept of "entry" altogether. See T. ALEINIKOFF \& D. MARTIN, supra note 15, at 342-47; Martin, supra note 188, at 806-07. This would mean that a unitary type of immigration hearing would test an alien's claim to be in the United States, in effect combining the statutory deportation and exclusion categories for most but not necessarily all purposes.

309. 333 U.S. 6, 10 (1948). See supra notes 117-20 and accompanying text.

310. See, e.g., Woodby v. INS, 385 U.S. 276, $286 \mathrm{n} .19$ (1966) ("This standard of proof applies to all deportation cases, regardless of the length of time the alien has resided in this country."); Squires v. INS, 689 F.2d 1276, 1280 (6th Cir. 1982); D. MARTIN, supra note 9, at 19 (Supreme Court applies "most lenient interpretation to ambiguous statutes or regulations, particularly in deportation cases, in light of the high stakes involved for the alien.").

311. Rosenberg v. Fleuti, 374 U.S. 449 (1963), discussed supra text accompanying notes 158-73.

312. 459 U.S. 21 (1982), discussed supra text accompanying notes 175-81.

313. See Joshi v. INS, 720 F.2d 799, 800-02 (4th Cir. 1983). The Board of Immigration Appeals has refused to apply Fleuti except in cases involving returning permanent residents. See Matter of Torres, Int. Dec. 3010 (BIA 1986); Matter of Mundell, 18 I. \& N. Dec. 467 (BIA 1983).

314. 464 U.S. 183 (1984).

315. INA § 244(a)(1), 8 U.S.C. § 1254(a)(1) (1988).

316. Fleuti, 374 U.S. at 461. 
sences for purposes of the seven-year continuous physical presence requirement. ${ }^{317}$ Phinpathya struck down this practice as contrary to the statute's plain meaning, rejecting the aliens' principal argument, that suspension, like the Fleuti exception, was meant to be "equitable and ameliorative." 318 But the lower courts' broad view of continuous physical presence was no more contrary to plain meaning than the Court's own reading of "entry" in Fleuti, which the Court reached in spite of evidence that Congress tried to limit exceptions to the reentry doctrine. In fact, Phinpathya read "continuous physical presence" narrowly in spite of evidence that Congress wanted a broader reading. ${ }^{319}$

One possible explanation for Phinpathya - though Justice O'Connor deemed it "not essential" to the decision-lies in her contrasting characterizations of Fleuti as a "lawful resident alien" and Phinpathya as "an unlawful alien who could have been deported even had she remained in this country."320 But these are just conclusory labels, and it is difficult to know how courts, in interpreting statutes, should distinguish between the Fleutis and the Phinpathyas of immigration law. ${ }^{321}$ It is difficult to know when to adhere strictly to a statute's "plain meaning" in spite of a harsh result, and when to take greater interpretive liberties to reflect a phantom constitutional norm, for example, that certain hardships should not be visited on some aliens with ties to this country. We should be troubled when the range of possible "reasonable" readings of a statute broadens to the point that little will surprise us.

As judges become more willing and able to address constitutional issues directly, rather than through subconstitutional reasoning, they should find that they do not need to grope for these awkward and unpredictable subconstitutional solutions. Similarly, Fleuti and the strain that it placed on the statute are needed less now than in 1963, thanks to Plasencia's expansion of judicial review to include openly constitutional due process challenges to exclusion procedures.

317. See, e.g., Phinpathya v. INS, 673 F.2d 1013, 1017-18 (9th Cir. 1981), rev'd, 464 U.S. 183, 193 (1984); Kamheangpatiyooth v. INS, 597 F.2d 1253, 1257 (9th Cir. 1979); Wadman v. INS, 329 F.2d 812, 815-17 (9th Cir. 1964).

318. 464 U.S. at 192-96.

319. Id. at 196-205 (Brennan, J., concurring). According to the majority, Congress thought that the definition of "entry" was too broad while the "continuous physical presence" requirement was intended "specifically to limit the discretionary availability of the suspension remedy." Id. at 193. Indeed, Congress wasted little time after Phinpathya to enact legislation that abrogated its result. Immigration Reform and Control Act $\S 315($ b), Pub. L. No. 99-603, 100 Stat. 3359 (1986), amended INA § 244, 8 U.S.C. $\S 1254(b)(2)$, to exclude "brief, casual, and innocent" absences that "did not meaningfully interrupt" continuous physical presence.

320. 464 U.S. at 194 (emphases in original). She added, "[s]uch an alien has no basis for expecting the Government to permit her to remain in the United States or to readmit her upon her return from foreign soil." Id. Her comment that this difference was "not essential" to the Court's decision, id., suggests that the distinction had some effect.

321. See also Tovar v. INS, 612 F.2d 794, 797-98 (3d Cir. 1980); cf. INS v. Hector, 479 U.S. 85, 88-91 (1986) (per curiam), which reversed, as contrary to the statute's "plain meaning," a court of appeals decision that had considered hardship to two nieces in determining extreme hardship for suspension of deportation under INA $\S 244(a)(1), 8$ U.S.C. $\$ 1101$ (b)(2)(1988), because their relationships were functionally indistinct from a parent-child relationship. 
The District of Columbia Circuit's 1988 decision in Rafeedie v. INS ${ }^{322}$ illustrates this shift nicely. The INS tried to exclude Rafeedie, a permanent resident and allegedly a high-ranking member of a Palestinian terrorist group, without a hearing under the summary exclusion statute when he tried to enter the country after a trip overseas. ${ }^{323}$ Rafeedie argued that that statute did not apply to permanent residents, and alternatively that the denial of a hearing resulting from its application violated due process. The district court rejected the statutory argument $t^{324}$ but found that the due process concerns were serious enough to merit a preliminary injunction barring summary exclusion, ${ }^{325}$ and the appeals court affirmed the grant of the injunction. ${ }^{326}$

In Rafeedie, a subconstitutional decision based on a phantom constitutional norm was unnecessary because Plasencia had recognized a returning permanent resident's due process rights as a constitutional matter! Both the district and the appeals courts addressed the constitutional issue directly without having to squeeze Rafeedie through the Fleuti loophole. ${ }^{327}$ In fact, the appeals court held that Fleuti's "meaningfully interruptive absence" test for statutory "reentry" would not decide if a returning permanent resident could claim procedural due process, even though some of the same factors would count. ${ }^{328}$ What might have been a phantom norm decision before Plasencia instead became a candid application of constitutional doctrine.

With such changes in constitutional immigration law giving judges new freedom to address constitutional claims directly, it seems less objectionable when a court breaks the Fong Haw Tan rule, which is the least precise subconstitutional solution, by refusing to read deportation statutes in favor of aliens in Phinpathya and similar cases. ${ }^{329}$ Nonetheless, a systemic problem with phantom norm decisionmaking is that even if these awkward or unpredictable solutions are needed less now than before, they remain with us after the transition from phantom to real is complete.

322. 880 F.2d 506 (D.C. Cir. 1989).

323. This, the INS argued, made him excludable under INA $\S \S 212(a)(27),(28)(F), 8$ U.S.C. $\S \S 1182(\mathrm{a})(27),(28)(\mathrm{F})(1988)$. It sought to exclude him without a hearing under INA $\S 235(\mathrm{c}), 8$ U.S.C. $\S 1225$ (c) (1988).

324. 688 F. Supp. $729,742-43$ (D.D.C. 1988).

325. Id. at 743-51.

326. 880 F.2d at 519 .

327. See 688 F. Supp. at 743 ("Plaintiff's real quarrel with Section 235(a) is a constitutional, not a statutory, one.").

328. 880 F.2d at 521-24.

329. See, e.g., INS v. Rios-Pineda, 471 U.S. 444, 451 (1985); INS v. Stevic, 467 U.S. 407 (1984); INS v. Jong Ha Wang, 450 U.S. 139, 143-44 (1981) (per curiam) (overturning liberal construction of "extreme hardship" because "the Act commits their definition [of "extreme hardship"] in the first instance to the Attorney General and his delegates, and their construction and application of this standard should not be overturned by a reviewing court simply because it may prefer another interpretation of the statute."). 


\section{B. The Problem of Misdirected Judicial Review}

Apart from awkwardness or unpredictability, subconstitutional phantom norm decisions, once established in response to problems of constitutional dimensions, set a precedent for excessive review of routine matters. By "excessive," I do not necessarily suggest "more" or "less" judicial review; explicit adoption of constitutional norms certainly would invite judicial scrutiny of agency decisions. Rather, I mean "excessive" in that the judicial habit of review not tied to real constitutional norms is open-ended and unbounded. As a result, courts may be least likely to intervene in agency decisionmaking when they can help most, and most likely to intervene when they can help least. The problem goes back as far as Fong Haw Tan, which by calling for interpretation of deportation statutes in the light most favorable to the alien, often asks courts to limit deference to agency interpretation of statutes. Much more recently, Jean v. Nelson $^{330}$ derived limits on INS discretion in parole decisions from phantom constitutional considerations, when the subconstitutional texts contained no express limitations.

Under a narrow reading of Jean, the INS abuses its parole discretion ${ }^{331}$ if it considers factors that conflict with phantom constitutional norms, whether or not a court would squarely hold unconstitutional a statute that expressly made those factors pertinent. ${ }^{332}$ Thus, it is an abuse of discretion to consider race in parole decisions, even if it is not directly unconstitutional. But it is difficult to avoid slipping into a slightly broader reading of Jean, especially (but not only) the reading that the INS abuses its discretion by considering factors not expressly authorized by statute or regulation. This reading is entirely understandable, since the prevailing view of Jean has not been to analyze it as a "phantom norm decision." Such a phantom norm analysis of Jean might help contain judicial review of agency action, but unless Jean is so limited, this slightly broader reading creates an open-ended and therefore troubling precedent for excessive judicial intrusion into agency decisionmaking. As Justice Marshall wrote in his dissent in Jean: "The Court's restrictive view of the Attorney General's discretionary authority with respect to parole decisions, adopted in the face of no authoritative statements limiting such discretion, will presumably affect the scope of his permissible discretion in areas other than parole deci-

330. 472 U.S. 846 (1985), discussed more fully supra text accompanying notes 237-55.

331. INA § 212(d)(5), 8 U.S.C. § 1182 (d)(5) (1988).

332. As Deborah Anker has suggested, the holding in Jean could have an even narrower meaning, that courts limit an agency's discretion when its conduct shows it to be unworthy of judicial deference. See Anker, supra note 9, at 11. This might apply to the INS in general, and to its treatment of Haitian asylum applicants in particular. But, as Anker points out, the opinion did not rely on these factors. Rather than assume that the INS mistreated Haitians, the Court remanded to the district court to find if the INS had discriminated against Haitians at all. Jean might also mean that the INS may not consider factors not reasonably related to the discretionary relief sought, in this case parole, but national origin seems closely related to a decision to grant or deny parole in a pending asylum case, if only with regard to likelihood of success on the application. 
sions. ... This is indeed a costly way to avoid deciding constitutional issues." 333

INS v. Rios-Pineda ${ }^{334}$ decided by the Court just six weeks before it decided Jean, reflects the more typical framework for judicial review of agency decisions. The Court said that it was not an abuse of discretion to deny certain motions to reopen suspension of deportation proceedings. The Court also emphasized that agencies must be free to base decisions on factors that relate generally to the law entrusted to it-in this case, "legitimate concerns about administration of the immigration laws. ${ }^{3335}$ These aspects of Rios-Pineda merely continued a tradition of judicial decisions that had established broad discretion for the INS. ${ }^{336}$ Two prominent examples are United States ex rel. Hintopoulos v. Shaughnessy $y^{337}$ and Jay v. Boyd, ${ }^{338}$ both of which involved the discretionary denial of aliens' requests for suspension of deportation. INS v. Abudu, a 1988 Supreme Court decision, adopts a similar approach, ${ }^{339}$ as have numerous lower court decisions. ${ }^{340}$

333. 472 U.S. at 867-68 (Marshall, J., dissenting); $c f$. Jean v. Nelson, 727 F.2d 957, 985-86 (11th Cir. 1984) (en banc) (Tjoflat, J., concurring in part and dissenting in part) (court may review agency action by Attorney General or by lower level officials to see if it is outside agency discretion, but it is impractical for court to ask if lower level officials' acts were consistent with internal agency directives), aff' $d$ as modified, 472 U.S. 846 (1985). If Judge Tjoflat is correct, fear of constitutional questions may make INS operations unduly rigid.

334. 471 U.S. 444 (1985).

335. Id. at 451-52.

336. See generally Anker, supra note 9, at 11.

337. 353 U.S. 72, 78 (1957) (proper for INS to consider "present-day conditions and congressional attitudes" in exercising discretion).

338. 351 U.S. 345, 358 (1956) (The Court felt "constrained to construe the statute as permitting decisions based upon matters outside the administrative record, at least when such action would be reasonable.").

339. 485 U.S. 94, 104-10 (1988). The Court also noted in Jean that the INS enjoys "broad statutory discretion" to deny parole. 472 U.S. at 857; $c f$. INS v. Cardoza-Fonseca, 480 U.S. 421, 446-48 (1987) (courts decide pure questions of statutory construction).

340. See, e.g., M.A. v. INS, 899 F.2d 304, 309-10 (4th Cir. 1990) (en banc). The Eleventh Circuit reached the same conclusion:

As we stated in Jean, Congress has delegated remarkably broad discretion to executive officials under the Immigration and Nationality Act, and these grants of statutory authority are nowhere more sweeping than in the context of parole of excludable aliens. . . . After thoroughly exploring the broad discretion given the Attorney General in making parole decisions, we concluded in Jean] that a federal court's scope of review in such instances is not the traditional abuse of discretion standard, but rather is limited to ascertaining whether he has advanced a "facially legitimate and bona fide reason' for his decision.

Garcia-Mir v. Meese, 766 F.2d 1446, 1478 (11th Cir. 1986), aff'd in part and rev'd in part, 766 F.2d 1022, cert. denied, 475 U.S. 1022 (1987); accord Jean v. Nelson, 727 F.2d 957, 975-79 (11th Cir. 1984) (en banc), aff' $d$ as modified, 472 U.S. 846 (1985); Narenji v. Civiletti, 617 F.2d 745, 747 (D.C. Cir. 1979) (INA "need not specifically authorize each and every action taken by the Attorney General, so long as his action is reasonably related to the duties imposed upon him."), cert. denied, 446 U.S. 957 (1980); Hotel \& Restaurant Employees Union, Local 25 v. Smith, 594 F. Supp. 502, 506 (D.D.C. 1984) (Attorney General has discretionary power to take actions and to "develop standards, principles and rules" as long as those decisions are based upon "considerations rationally related to the statute he is administering.") (quoting Fook Hong Mak v. INS, 435 F.2d 728, 730 (2d Cir. 1970)), aff'd in relevant part and rev'd in part on other grounds, 804 F.2d 1256 (D.C. Cir. 1986), aff'd by an equally divided court, 846 F.2d 1499 (D.C. Cir. 1988) (en banc). 
Courts that get into the habit of using expanded "abuse of discretion" and similar subconstitutional constructs to apply phantom constitutional norms indirectly are likely to succumb to the temptation to define "legitimate" so broadly that they in effect try to run the agency. While this may be understandable in light of the record of the INS, ${ }^{341}$ judicial review still represents the commitment of a precious resource. Review of the wrong type is an uncertain improvement over no judicial review at all. ${ }^{342}$ And the problem is compounded when judicial review is not only misdirected but also imposes cumbersome or unworkable procedures. ${ }^{343}$

Plenary power has prevented the growth of a coherent constitutional framework for immigration law, within which its subconstitutional levels-statutes, regulations, agency directives, and so forth-can develop and be administered fairly and predictably. There is a paradox here. On the one hand, the courts adopted the plenary power doctrine to insulate immigration decisions from constitutional judicial review. Judicial sensitivity to the need to maintain the flexibility to respond to unexpected contingencies, especially pertaining to foreign policy, may explain some of the plenary power doctrine's persistencefor example, the Supreme Court decided Knauff, Mezei, and Harisiades at the height of the nation's preoccupation with the perceived Communist threat. The irony is that the steady erosion of the plenary power doctrine through phantom norm decisionmaking may, precisely because no coherent body of constitutional norms exists to anchor and thus limit judicial review in immigration cases, lead to subconstitutional decisions that intrude into executive or legislative operations even more aggressively. There may be times when agency decisionmaking, to reach the best results, should be able to apply expertise, discretion,

341. Cf. Trillin, Making Adjustments, THE NEW YORKER (May 18, 1984) ("WW]hen people who deal regularly with the I.N.S. try to illustrate the depths of its inefficiency and obduracy, they often find themselves at a loss for American institutions to compare it with, and turn to foreign examples-the South Vietnamese Army, maybe, or the Bolivian Foreign Service.").

342. See generally Sofaer, Judicial Control of Informal Discretionary Adjudication and Enforcement, 72 COLUM. L. REV. 1293 (1972); Sofaer, The Change-of-Status Adjudication: A Case Study of the Informal Agency Process, 1 J. LEGAL STUD. 349 (1972).

343. See Aleinikoff, Aliens, Due Process and "Community Ties": A Response to Martin, 44 U. PITT. L. REV. 237, 259 (1983) (problem with plenary power doctrine is that it prevents continuing dialogue between courts and Congress on due process, so that when government conduct becomes "outrageous," "courts are forced to leap in with both feet, demanding costly and intrusive procedures that make control of the borders and deportation of aliens considerably more difficuit."); Martin, supra note 103, at 171 ("Casting an eye over the procedural exuberance of the lower courts—-procedural rulings theoretically applicable, without discernible limitation, to anyone in the world who presents himself at our borders-may well prompt a retreat to something like Knauff-Mezei."); Schuck, supra note 6, at 82-85 (discussing problems that could result from "active, intrusive judicial role in immigration cases," among them "ever more formalized, extensive hearing procedures whose effects, apart from increased cost and delays, are uncertain and quite possibly perverse"); Verkuil, A Study of Immigration Procedures, 31 UCLA L. REv. 1141, 1179 . 82 (1984) (parole-detention cases show that lack of administrative review of informal procedures may lead to judicial intervention, which in turn may lead to more procedural formality of discretionary decisions, more judicial review, or both). 
and flexibility after considering the unusual and the unpredictable. ${ }^{344}$ Since Mandel, the most negative effects of phantom norm decisions have been to impede the sound exercise of executive branch discretion. Tight supervision may correct short-run problems, but in the long run it also prevents immigration law from maturing and thus continues its traditional isolation-albeit isolation of a different character-from the mainstream of our public law.

\section{The Problem of Dialogue and the Future of Plenary Power}

Awkward or unpredictable solutions and misdirected judicial review are symptoms of a more basic condition. Immigration law after a century of plenary power has two conflicting sets of constitutional norms. In each of the four areas discussed in Part III.B, constitutional immigration law remains tied to the key plenary power cases. And the Court has continued to rebuff constitutional challenges to substantive, directly legislative choices. The most prominent recent case of Fiallo $v$. Bell, ${ }^{345}$ decided in 1977, challenged the statute that recognized only an illegitimate child and mother, but not the father, as parent and child for immigration purposes. ${ }^{346}$ The Court rejected an equal protection attack on two classifications in the statute-gender and legitimacy-that usually trigger something more than casual scrutiny. ${ }^{347}$

344. The type of case that may raise concerns about excessive judicial review is Hotel \& Restaurant Employees Union, Local 25 v. Smith, 563 F. Supp. 157 (D.D.C. 1983), 594 F. Supp. 502, 507-09 (D.D.C. 1984), aff'd in relevant part and rev'd in part on other grounds, 804 F.2d 1256 (D.C. Cir. 1986), aff'd by an equally divided court, 846 F.2d 1499 (D.C. Cir. 1988) (en banc). The case involved "extended voluntary departure," which is the discretionary INS practice of letting some aliens, usually by nationality group, stay in the country for humanitarian reasons even though they may lack a meritorious case for political asylum or other formal status. The plaintiff union argued that the INS decision to deny extended voluntary departure to Salvadorans, while granting it to other nationalities, was "arbitrary and capricious and an abuse of discretion." Judge Richey asserted a power of limited judicial review, explaining that "abuse of discretion ... can be shown by demonstrating a violation of constitutional, statutory, regulatory or other legal mandates." 563 F. Supp. at 162. Later, he entered summary judgment for the INS, finding no abuse of discretion because it had a "facially legitimate" reason for its decision, and the appeals court affirmed. 594 F. Supp. at 508. Had the Supreme Court already decided Jean, Judge Richey might well have inquired more deeply. Cf. American Baptist Churches v. Thornburgh, No. C 85-3255 FRP (N.D. Cal. 1989), digested in 66 INTERPRETER RELEASES 1061-63 (1989) (citing American-Arab to deny government's motions to dismiss and for summary judgment where plaintiffs claimed illegal discrimination against Salvadorans and Guatemalans in asylum applications and grants of extended voluntary departure); see also American Baptist Churches v. Meese, 712 F. Supp. 756, $767-74$ (N.D. Cal. 1989). See generally Schuck, supra note 6, at 59-62; Note, Extended Voluntary Departure: Limiting the Attorney General's Discretion in Immigration Matters, $85 \mathrm{MICH}$. L. REV. 152 (1986).

345. 430 U.S. 787 (1977).

346. INA § 101(b)(1)(D), 8 U.S.C. \& 1101(b)(1)(D) (1988), then provided that a "child" includes "an illegitimate child, by, through whom, or on whose behalf a status, privilege, or benefit is sought by virtue of the relationship of the child to its natural mother." See Fiallo, 430 U.S. at 797 (1977). Later, a 1986 amendment included fathers with "a bona fide parent-child relationship." Immigration Reform and Control Act § 315(a), Pub. L. No. 99-603, 100 Stat. 3359 (codified at INA § 101(b)(1)(D), 8 U.S.C. § 1101(b)(1)(D) (1988)).

347. See, e.g., Trimble v. Gordon, 430 U.S. 762, 766-76 (1977) (legitimacy); Califano v. Webster, 430 U.S. 313, 317 (1977) (gender); Califano v. Goldfarb, 430 U.S. 199, 210-11 (1977) (gender); Craig v. Boren, 429 U.S. 190, 197 (1976) (gender); Jimenez v. Weinberger, 417 U.S. 628 (1974) (legitimacy); Gomez v. Perez, 409 U.S. 535, 538 (1973) (legitimacy). 
Signs of change now appear on the horizon, in the form of expressly constitutional lower court decisions that have refused to accept the plenary power doctrine as controlling. While Fiallo clearly relied on the plenary power doctrine in rejecting the constitutional claim, ${ }^{348}$ the Court left the door slightly ajar for judicial review by characterizing the statute as " "largely immune from judicial control." "349 Lower courts have taken this statement, sometimes together with Mandel's "facially legitimate and bona fide reason" test, to support limited judicial review using a rational basis test. A few lower courts have held immigration classifications to lack a rational basis and therefore to violate equal protection. For example, the Second Circuit held in Francis v. INS ${ }^{350}$ that, absent a rational basis, the BIA violated equal protection when it interpreted the statute to distinguish, for purposes of granting discretionary waivers, between permanent residents who had temporarily left the United States after becoming deportable and those who had not left. ${ }^{351}$

In 1989, a district court in American-Arab Anti-Discrimination Committee v. Meese $e^{352}$ sustained a First Amendment challenge to several ideological deportation grounds as applied to two permanent residents and six nonimmigrant aliens, based on their alleged affiliation with a Marxist group, the Popular Front for the Liberation of Palestine. ${ }^{353}$ The court reasoned that the provisions

348. 430 U.S. at 799. See also Landon v. Plasencia, 459 U.S. 21, 34-35 (1982) ("role of the judiciary is limited to determining whether the procedures meet the essential standard of fairness under the Due Process Clause and does not extend to imposing procedures that merely displace congressional choices of policy"). Interestingly, Fiallo cited Mandel more broadly, in support of the plenary power doctrine generally. Fiallo, 430 U.S. at 799.

349. 430 U.S. at 792 (quoting $M e z e i, 345$ U.S. at 210) (emphasis added); see also 430 U.S. at 793 n.5 ("Our cases reflect acceptance of a limited judicial responsibility under the Constitution even with respect to the power of the Congress to regulate the admission and exclusion of aliens."); id. at 795-96 n.6 ("This is not to say, as we make clear in n.5, supra, that the Government's power in this area is never subject to judicial review."). The lower court in Fiallo similarly reasoned that distinguishing between unwed mothers and fathers was neither "wholly devoid of any conceivable rational purpose" nor "fundamentally aimed at achieving a goal unrelated to the regulation of immigration." Fiallo v. Levi, 406 F. Supp. 162, 166 (E.D.N.Y. 1975), aff'd sub nom. Fiallo v. Bell, 430 U.S. 787 (1977).

The plenary power cases in the early 1950 's had hinted at some limited constitutional judicial review. See Harisiades v. Shaughnessy, 342 U.S. 580, 589-90 (1952) ("policy toward aliens" is "largely immune" from judicial review; issue is whether "congressional alarm" about "Communist conspiracy within the United States is either a fantasy or a pretense"). Harisiades rejected the view "that there were then or are now no possible grounds on which Congress might believe that Communists in our midst are inimical to our security." Id. at 590 (emphasis added); see also Carlson v. Landon, 342 U.S. 524, 544 (1952) ("no denial of ... due process ... where there is reasonable apprehension of hurt from aliens charged with a philosophy of violence against this Government").

350. 532 F.2d 268 (2d Cir. 1976)

351. Francis concerned interpretation of INA § 212(c), 8 U.S.C. § 1182(c) (1988). The Ninth Circuit followed Francis in Tapia-Acuna v. INS, 640 F.2d 223, 225 (9th Cir. 1981). Cf. Immigration Assistance Project v. INS, 709 F. Supp. 998, 1002-03 (W.D. Wash. 1989) (equal protection violation because no rational basis for distinguishing between groups of legalization applicants); $c f$. Elias v. Department of State, 721 F. Supp. 243, 247-50 (N.D. Cal. 1989) (no "facially legitimate and bona fide reason" to let citizen fathers, but not mothers, transmit citizenship to offspring born abroad).

352. 714 F. Supp. 1060,1063 (C.D. Cal. 1989).

353. The deportation grounds at issue were INA $\S \S 241(\mathrm{a})(6)(\mathrm{D}),(\mathrm{F})(\mathrm{iii}),(\mathrm{G})(\mathrm{v}),(\mathrm{H}), 8$ U.S.C. $\S \S 1251(\mathrm{a})(6)(\mathrm{D}),(\mathrm{F})(\mathrm{iii}),(\mathrm{G})(\mathrm{v}),(\mathrm{H})$ (1988). $714 \mathrm{~F}$. Supp. at 1062. The court did not reach plaintiffs' argument that sections 901(a) and (b) of the Foreign Relations Authorization Act, Fiscal Years 1988 and 
were unconstitutional because the same activities, if engaged in by citizens, would be protected by the First Amendment. ${ }^{354}$ The court relied heavily on Chew and Justice Murphy's concurrence in Bridges, ${ }^{355}$ and also cited Plyler v. $D o e^{356}$ as authority in rejecting the government's argument that "a fundamentally 'different' Bill of Rights applies to aliens seeking to avoid expulsion from the United States." 357

Harvard Law School Forum v. Shultz, ${ }^{358}$ a 1986 district court decision, took the "facially legitimate and bona fide reason" language, which Allende and El-Werfalli took from Mandel and applied to heighten subconstitutional judicial scrutiny, and reintroduced it at the constitutional level to recognize a First Amendment challenge of the sort that $M a n d e l$ had rejected. The case concerned the government's refusal to let a member of the Palestine Liberation Organization's mission to the United Nations travel to Harvard to participate in a political forum. The analysis began by relying heavily on Allende $e^{359}$ but then moved quickly to the constitutional level. In reasoning that ran counter to Mandel, the court found that under the First Amendment the government's justification for refusing permission was "not facially legitimate because it is related to the suppression of protected political discussion." 360

Another recent case, Manwani v. INS, ${ }^{361}$ sustained substantive constitutional challenges to section five of the Immigration Marriage Fraud Amendments of $1986^{662}$ on the grounds that it imposes an impermissible irrebuttable presumption and violates equal protection. ${ }^{363}$ That section bars immigration

1989, Pub. L. No. 100-204, \& 901, 101 Stat. 1331, 1399 (1987), were also unconstitutional.

354. In reaching this conclusion, the court read Harisiades, which rejected a First Amendment challenge, as having applied the same First Amendment standard to aliens and citizens. The district court reasoned that First Amendment law had changed in the meantime, since the precedent cited by the Harisiades, Dennis v. United States, 341 U.S. 494 (1951), had been superseded by later cases, most prominently Brandenburg v. Ohio, 395 U.S. 444 (1969). See discussion of Harisiades supra note 68.

355. 714 F. Supp. at 1074, 1076. Bridges v. Wixon, 326 U.S. 135 (1945), is discussed supra text accompanying notes $109-16$.

356. 714 F. Supp. at 1075 n.11. Plyler v. Doe, 457 U.S. 202 (1982), is discussed supra text accompanying notes 196-99.

357. 714 F. Supp. at 1079.

358. 633 F. Supp. 525 (D. Mass. 1986).

359. Id. at 531 .

360. Id. at 531. cf. United States v. Aguilar, 871 F.2d 1436, 1468-70 (9th Cir. 1989) (prosecuting sanctuary movement members for smuggling undocumented aliens does not abridge free exercise); American Friends Serv. Comm. v. Thornburgh, 718 F. Supp. 820, 822-23 (C.D. Cal. 1989) (IRCA employer sanctions do not abridge free exercise), appeal docketed, No. 89-56095 (9th Cir. 1989).

361. 736 F. Supp. 1367 (W.D.N.C. 1990).

362. Pub. L. No. 99-639, 100 Stat. 3537 (1986) (codified at INA $\S 204(\mathrm{~h}), 8$ U.S.C. $\S 1154$ (h) and INA $\S 245(\mathrm{e}), 8$ U.S.C. $\$ 1255(\mathrm{e})$ (1988)).

363. 736 F. Supp. at 1386-92. The district court also found violations of procedural due process rights. Id. at 1383-86. In contrast, a panel of the District of Columbia Circuit relied on characterizing the statute as violating procedural due process because it delayed for two years an affected couple's opportunity to prove their marriage bona fide. See Escobar v. INS, 896 F.2d 564, 567-73 (D.C. Cir. 1990), rev'g 700 F. Supp. 609, 611-13 (D.D.C. 1988), withdrawn and reh'g en banc granted (Apr. 25, 1990). The Supreme Court rejected a similar argument in Fiallo v. Bell. See 430 U.S. 787, 791 (1977). The reasoning in Escobar illustrates an interesting variation on phantom norm decisionmaking. Rather than give a statute a particular interpretation, it casts the statute as "procedural," which makes the constitutional challenge more likely to 
based on a marriage entered into while deportation proceedings are pending, unless the alien first leaves the country for two years. ${ }^{364}$ Both Yick Wo progeny-Wong Wing, Russian Volunteer Fleet, Mathews v. Diaz, and Plyler v. Doe-and phantom norm decisions-Chew and Wong Yang Sung-figured centrally in the district court's reasoning. ${ }^{365}$ This pattern-reliance upon both phantom norm decisions and the line of cases from Yick Wo to Plyler-is likely to be the reasoning in other decisions undermining or limiting the plenary power doctrine, just as it was, for example, in Justice Douglas' dissent in Harisiades ${ }^{366}$ and Justice Marshall's dissent in Jean. ${ }^{367}$

These recent cases notwithstanding, the key Supreme Court constitutional precedents-Knauff, Mezei, and Harisiades being the most prominent among them-still severely limit judicial review. Almost always, substantive rules made directly by Congress have withstood constitutional challenge. ${ }^{368}$ The Court may someday disavow the plenary power doctrine, but that step will take time. In the meantime, however, courts will continue to avoid this directly applicable constitutional doctrine through subconstitutional decisions that rely on phantom constitutional norms much more favorable to aliens. Cases that purport to speak only subconstitutionally have become the indirect expression of an alternative body of constitutional immigration law in which the plenary

succeed.

364. INA § 204(h), 8 U.S.C. § 1154(h) (1988).

365. Manwani, 736 F. Supp. at 1375-76, 1382-83, 1388-90.

366. 342 U.S. 580, 598-99 (Douglas, J., dissenting) (citing Yick Wo, Wong Wing, Russian Volunteer Fleet, and other cases).

367. 472 U.S. 846, 872-75 (Marshall, J., dissenting) (citing Chew, Wong Wing, Russian Volunteer Fleet, and Yick Wo). Cf. Note, The Constitutional Rights of Excludable Aliens: History Provides a Refuge, 61 WASH. L. REV. 1449 (1986) (proposing analytical framework based on Wong Wing and Yamataya to replace plenary power doctrine). Jean is discussed in greater detail supra text accompanying notes 237-55.

368. See, e.g., Newton v. INS, 736 F.2d 336, 339-42 (6th Cir. 1984) (excluding exchange visitors from eligibility for suspension of deportation); Nademi v. INS, 679 F.2d 811, 814-15 (10th Cir. 1982) (treating Iranians differently after taking of Tehran hostages), cert. denied, 459 U.S. 872 (1982); Sadegh-Nobari v. INS, 676 F.2d 1348, 1351 (10th Cir. 1982) (same); Malek-Marzban v. INS, 653 F.2d 113, 116 (4th Cir. 1981) (same); United States v. Barajas-Guillen, 632 F.2d 749, 752-54 (9th Cir. 1980) (voluntary departure rules tending to exclude indigent aliens); Narenji v. Civiletti, 617 F.2d 745, 747-48 (D.C. Cir. 1979), cert. denied, 446 U.S. 957 (1980) (classifying aliens by nationality); Menezes v. INS, 601 F.2d 1028, 1034 (9th Cir. 1979) (treating fiances and spouses of United States citizens differently in inquiring into bona fides of marriage); Castillo-Felix v. INS, 601 F.2d 459, 467 (9th Cir. 1979) (applying different readings of INA section in different circuits); Alvarez v. District Director, 539 F.2d 1220, 1224 (9th Cir. 1976) (limiting special treatment of "commuter aliens" to aliens from contiguous countries); Guan Chow Tok v. INS, 538 F.2d 36, 38 (2d Cir. 1976) (deporting narcotics offenders); Noel v. Chapman, 508 F.2d 1023, 1028-29 (2d Cir. 1975) (different extended voluntary departure rules for spouse of citizens and of permanent residents); Dunn v. INS, 499 F.2d 856, 859 (9th Cir. 1974) (distinguishing Eastern and Western Hemisphere aliens for relief from deportation), cert. denied, 419 U.S. 1016 (1975).

Other recent cases have upheld the constitutionality of $\$ 5$ of the Immigration Marriage Fraud Amendments of 1986, Pub. L. No. 99-639, 100 Stat. 3537. See Almario v. Attorney Gen., 872 F.2d 147, 151 (6th Cir. 1989) ("Kleindienst and Fiallo require that we exercise a very narrow standard of review assuming the classification at issue in this case is supported by a facially legitimate and bona fide reason"; purpose is to deter marriage fraud); see also Azizi v. Thornburgh, 908 F.2d 1130 (2d Cir. 1990), aff' \& 719 F. Supp. 86, 89-96 (D. Conn. 1989); Anetekhai v. INS, 876 F.2d 1218, 1221-24 (5th Cir. 1989), aff' $g 685$ F. Supp. 599 (E.D. La. 1988); Minatsis v. Brown, 713 F. Supp. 1056, 1060-61 (S.D. Ohio 1989); Smith v. INS, 684 F. Supp. 1113, 1116-20 (D. Mass. 1988). 
power doctrine has lost much of its force. From this broader perspective, the practical demise of the plenary power doctrine seems closer in time. ${ }^{369}$

One basic problem that arises in this situation is that it is difficult accurately to identify and distinguish between constitutional and subconstitutional immigration law. Was Woodby a constitutional or subconstitutional decision? What about Jean? What are the limits of Congress' power to legislate different results in those situations? A related point is that the alternative body of phantom constitutional norms is relatively inaccessible. Litigants and judges know, in a loose way, about the gradual erosion of plenary power, but they generally do not distinguish between directly applied constitutional law and the alternative body of phantom norm decisions. Inaccessibility in turn limits the range of litigants' arguments and judges' decisions.

The inaccessibility problem forms part of a much larger and more fundamental difficulty. If the constitutional norms that courts use to interpret statutes to avoid constitutional doubt are phantoms, then those norms may not guide, but may misguide. In fact, the phantom norms actually turn on its head the practice of interpreting statutes to avoid constitutional doubt. If we heed the plenary power doctrine, there is no real doubt to be avoided, but courts, perhaps hearing the echo of Yick Wo, nonetheless assume the existence of a constitutional question and answer it by relying on a phantom norm. Concerns for legislative supremacy, which arise whenever courts bend statutes by relying on a constitutional norm, ${ }^{370}$ are even greater when the norm is a phantom. ${ }^{371}$ In this sense, mainstream public law decisions that avoid constitutional issues only by severely straining the statutory text ${ }^{372}$ may be more defensible than Chew or Fleuti, because those mainstream decisions at least respond to real constitutional norms. After the gradual enhancement of the constitutional status of permanent residents, and especially after Plasencia, we can look back and believe that Chew was "correctly" decided. But for other norms that have yet to become "real," for instance in the four currently important areas of immigration law discussed in Part III.B, we lack the comfort of hindsight, and the problem of misguided statutory interpretation looms large.

369. Cf. Legomsky, supra note 5, at 303 ("We have entered a new phase in the life of the plenary power doctrine. This stage is characterized by a judicial willingness, so far episodic, to cut away at the notion of plenary Congressional power over immigration."); id. at 305 ("Constitutional review of immigration legislation will enter another, perhaps final, stage. This next stage will be marked by a return to general principles of constitutional law. It will be unnecessary for courts to distinguish immigration statutes from other federal statutes."); Schuck, supra note 6, at 34 ("Capitulation seems only a matter of time for some of these doctrines, while for others the outcome remains highly uncertain."); $i d$. at 58 (increasing willingness of courts to review immigration decisions "essentially remains a lower court phenomenon").

370. See Eskridge, supra note 74, at 1065-73.

371. Thus, Judge Posner's critical observation that the canon leads to overenforcement of constitutional norms, see R. POSNER, supra note 75 , at 285 , has greater merit when directed toward immigration law's phantom norm decisions, even if, as Sunstein argues, Posner is incorrect as to constitutional law generally because those norms are real even though underenforced. See Sunstein, supra note 77, at 469 .

372. See, e.g., NLRB v. Catholic Bishop, 440 U.S. 490 (1979), discussed in Eskridge, supra note 74, at $1022,1066$. 
One defense of phantom norm decisions is that they have been a useful testing ground for new constitutional ideas without the need to challenge prevailing doctrine. What began subconstitutionally-first with Chew, then Fleuti-may lead ultimately to an expressly constitutional change-such as in Plasencia-as phantom subconstitutional decisions undermine the existing constitutional structure to the point that it topples. ${ }^{373}$ As I suggested in the Introduction, this process may be a healthy, perhaps preferred, and perhaps even inevitable form of constitutional change. Still, this pattern has taken an extreme form in immigration law. What seems aberrant is the persistence, beyond any reasonable definition of "transitional phase," of real, plenary power-based constitutional norms in immigration law, as well as the degree of conflict between them and the phantom norms from the Yick Wo tradition that guide statutory interpretation.

As a result, phantom constitutional norms and directly applicable constitutional immigration law provide little by way of dialogue en route to new constitutional doctrine. Instead, the tension between the plenary power doctrine and subconstitutional phantom norm decisions has caused considerable damage to the process of dialogue about the future of immigration law. Each body of constitutional immigration law has its adherents. Government briefs in immigration cases rely heavily on directly applicable constitutional immigration law, while advocates for aliens cite the subconstitutional phantom norm decisions. Each of these two groups of cases seems determined to speak in a louder voice, each hoping to drown out the other, but there is no conversation. This absence of dialogue is what convinces me that immigration law is an extreme case, where phantom norm decisionmaking has lingered beyond a period of honest, tentative groping and experimentation and into a phase in which it has become mere technique and perhaps even subterfuge. ${ }^{374}$

In spite of these many problems, any overall assessment of phantom norm decisionmaking should reflect a more basic ambivalence. It oversimplifies the history to identify only the problems and, with the acuity of hindsight, say that these judges were just renegades who disliked the prevailing constitutional

373. Cf. L. FULLER, LEGAL FICTIONS (1967) (legal fictions are ephemeral building blocks of legal communication, to be discarded when no longer useful).

374. See generally G. CALABREST, A COMMON LAW FOR THE AGE OF STATUTES 178-81 (1982). In the short run, any movement away from phantom norm decisionmaking and toward more direct dialogue may deprive aliens of a strategy of argumentation that has helped them in many of the cases discussed in this Article. Certainly in the lower courts, judicial candor about the exact nature of the constitutional norms that inform interpretation of statutes may briefly strengthen the precedential force of the key plenary power cases such as Mezei, Knauff, and Harisiades. For a while, then, aliens may lose a few more immigration cases than before. But I believe that this movement will hasten the complete demise of the plenary power doctrine for two reasons. First, the case for abandoning the doctrine will become more compelling because courts no longer will be able to rely on the mechanism - phantom norm decisionmaking-through which they effectively have accomplished a partial integration of immigration law into mainstream public law. And second, when the extent of that integration becomes more widely known, express application of mainstream public law norms in immigration cases will seem less radical, and indeed sometimes consistent with precedent. In the long run, the end of plenary power should be worth the interim price. 
immigration law and acted lawlessly in smuggling in constitutional rules more to their liking. Phantom norm decisions have been an understandable and perhaps even noble response by conscientious judges to the perceived anachronistic character of plenary power. We have these decisions to thank for the fact that the Constitution is not as far removed from immigration law as the plenary power doctrine would suggest. These decisions have been the only means by which immigration law has moved beyond the nineteenth-century world of classical immigration law and come to reflect, in some small part, the values, embodied in the Yick Wo tradition, that are more consistent with our modern sense of justice. The dissonance between immigration law and our mainstream public law has made some judges feel that they must find a way to harmonize the two. Some of those judges have been Justices of the Supreme Court of the United States, as Chew, Jean, and other cases amply demonstrate. They, like lower court judges, have felt constrained by precedent to render decisions that give them some considerable discomfort, but not enough discomfort to prompt the immediate creation of a new constitutional immigration law.

To move confidently into the second century of immigration law, we need to understand what went wrong in the first century. The development of a subconstitutional case law based on phantom constitutional norms is persuasive evidence that as long as judges have discretion to decide cases, no area of law, not even immigration law, can hope to insulate itself forever from the rest of our legal culture. This was the vain hope, and ultimately the failure, of the plenary power doctrine.

The future of immigration law requires considerable thought and discussion. To what extent should the analytical framework that applies in the mainstream of our public law apply to immigration cases? To what extent should the answers be the same or different because immigration is at issue? And ultimately, who are "we" as a community, and what do we demand of those who want to join? The most fundamental problem with the plenary power doctrine is that it has seriously impaired the process of dialogue on these questions, whatever the best answers may be. We will begin to restore dialogue only when courts, including the Supreme Court in cases like Jean v. Nelson, take the next step and begin to put their constitutional thinking in expressly constitutional terms. 
